$\mathrm{N}^{\circ} 2000-\mathrm{n}^{\circ} 18$

December

Ex D'IMTonhations

INTEENATHOEALE

Capital Stock and Productivity in French Transport : An International Comparison

Bernard Chane Kune Nanno Mulder 

Capital Stock and Productivity in French Transport : An International Comparison

Bernard Chane Kune Nanno Mulder

$$
\begin{array}{r}
N^{\circ} 2000-n^{\circ} 18 \\
\text { December }
\end{array}
$$





\section{TABLE OF CONTENTS}

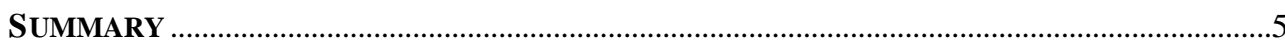

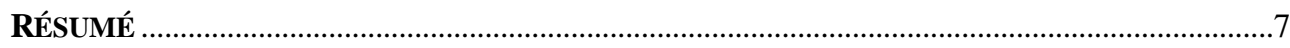

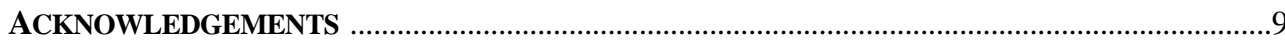

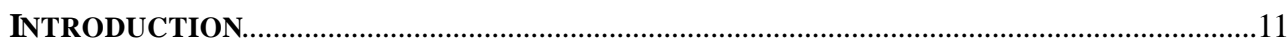

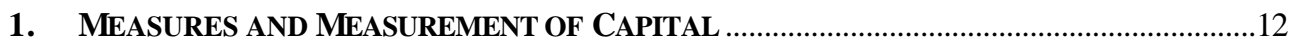

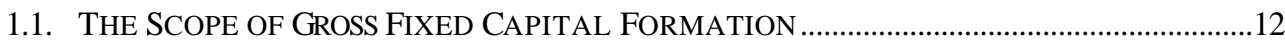

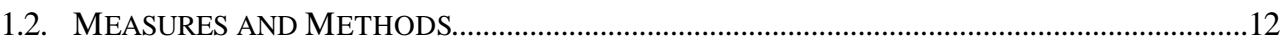

1.2.1. The Contribution of Capital to Production: Stocks or Services..........................12

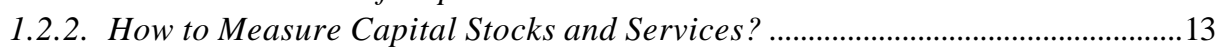

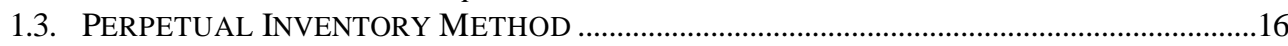

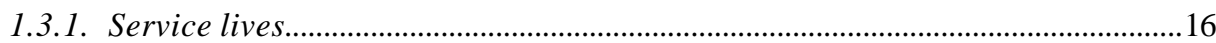

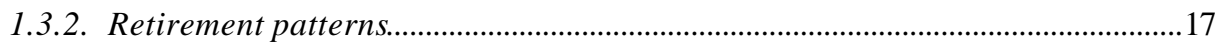

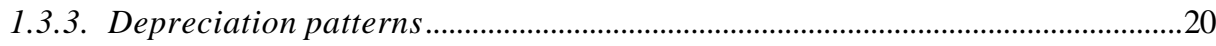

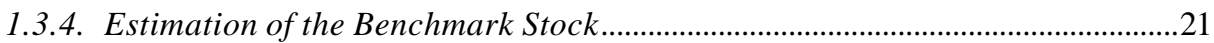

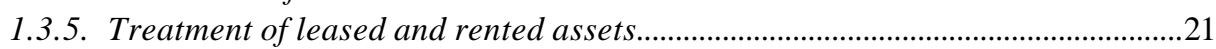

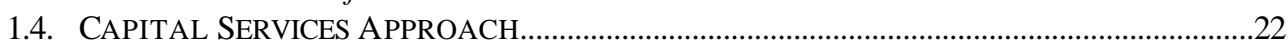

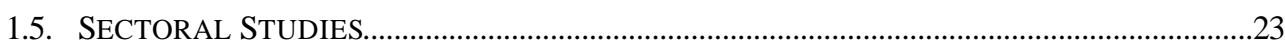

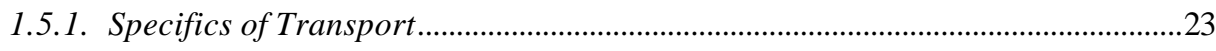

1.5.2. The Canadian Centre for Transportation Studies ................................................23

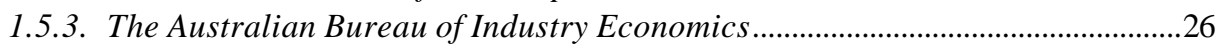

1.5.4. Capital Stock Estimates in American Transport.....................................................26

2. CAPITAL FORMATION AND CAPITAL STOCK IN FRENCH TRANSPORT .......................27

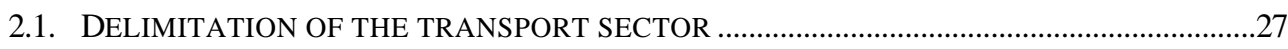

2.2. SOURCES OF GROSS FIXED CAPITAL FORMATION AND CAPITAL STOCKS ....................27

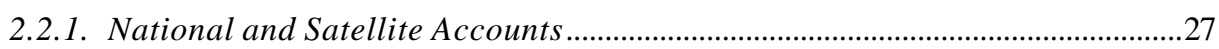

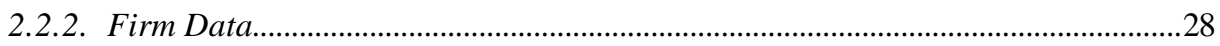

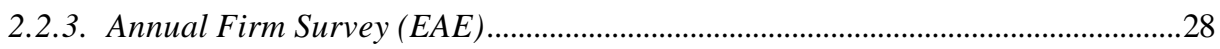

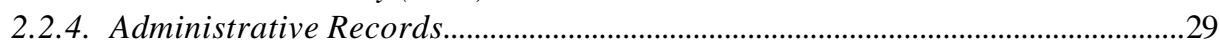

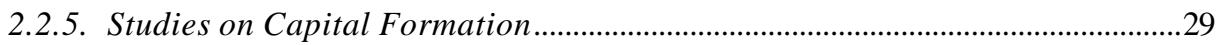

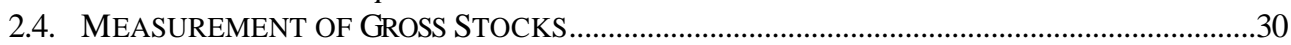

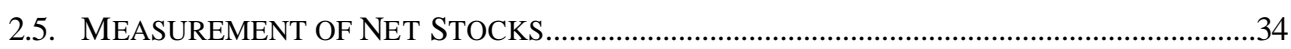

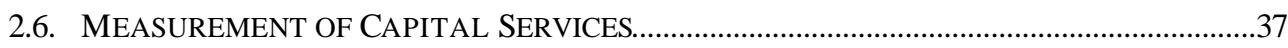


3. THE AIRCRAFT STOCK MEASURED BY ADMINISTRATIVE RECORDS ...........................38

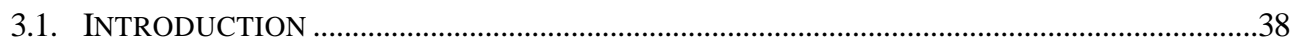

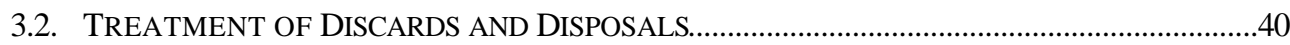

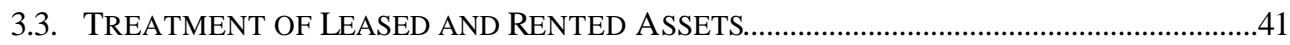

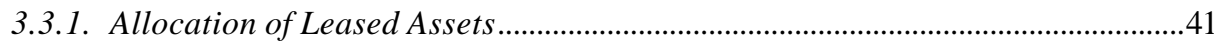

3.3.2. Measurement of the Leased Capital Stock using the PIM......................................41

3.4. USING ADMINISTRATIVE RECORDS TO MEASURE GROSS AND NET CAPITAL STOCKS42

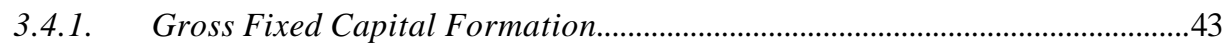

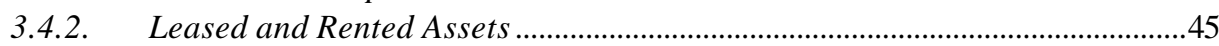

3.5. COMPARISON OF CAPITAL STOCKS BASED ON THE PIM AND ON REGISTERS................47

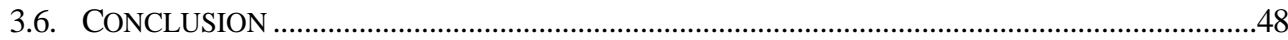

4. INTERNATIONAL PRODUCTIVITY COMPARISONS …....................................................48

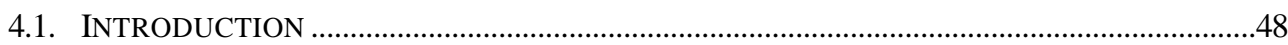

4.2. PRODUCTIVITY PERFORMANCE: A COMPARISON BETWEEN THE FRENCH SECTORS.49

4.3. INTERNATIONAL COMPARISONS OF PRODUCTIVITY IN TRANSPORT ............................52

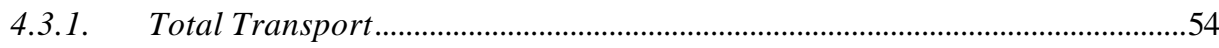

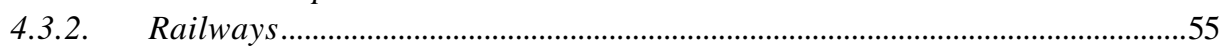

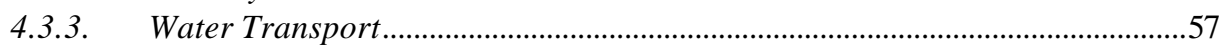

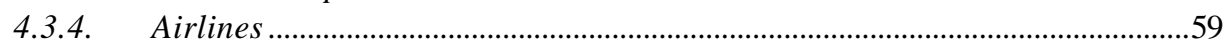

4.3.5. Road Freight, Road Passenger and Services Related to Transport ...............62

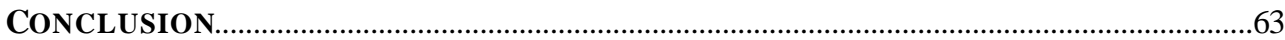

ANNEX A - FrenCH INDUSTRIAL CLASSIFICATION: NAP AND NAF ...................................67

ANNEX B - SERIES OF GROSS FIXED CAPITAL FormatION.................................................69

ANNEX C - CAPITAL Formation at Constant AND CURRENT PRICES ...........................77

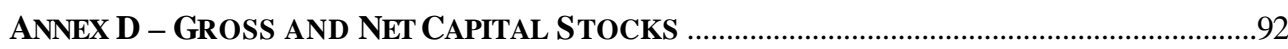

ANNEX E - GDP, EMPLOYMENT, AND LABOUR SHARES IN FRANCE ...............................102

ANNEX F - TIME SERIES FOR OTHER COUNTRIES ................................................................111

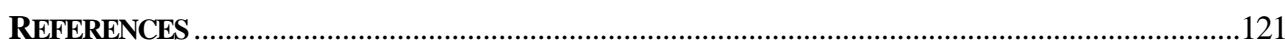

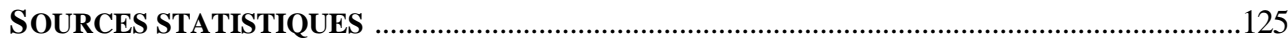

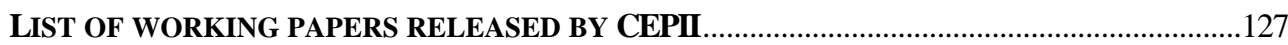




\section{SUMMARY}

The efficiency of service providers is often approximated by labour productivity. This partial measure is considered as a proxy of overall efficiency as many services use relatively little capital. However, in many services such as transport, capital is a major production factor. To judge the overall efficiency of these services, labour productivity measures should therefore be complemented by measures of capital and total factor productivity (TFP). For France, to date capital productivity and TFP could not be estimated for individual branches of transport as no capital input estimates were available at this level.

This paper aims to fill this gap by providing new detailed estimates of capital input in French transport from 1970 onwards. These data are used in combination with series on output and labour input to estimate productivity. Finally, the French performance is compared with that of Germany, the United Kingdom and the United States.

In contrast to many other studies on productivity, the contribution of capital to production is not measured by the value of the stock of assets but by the volume of services rendered by this stock (as employed in Jorgenson et al., 1987). An inconvenience of using (gross or net) capital stocks for productivity analysis is that all other variables (such as value added and hours worked) are flows. Capital services are the flows of a capital good into production. Capital services are the product of the quantity of capital (supposed proportional to the net stock) times the rental price of capital (the sum of depreciation, the real interest rate and capital gains).

Ideally the way to measure net capital stocks is by comprehensive direct surveys. Contrary to for example the Netherlands, no such surveys exist in France. The second best method, also used in this study, is the perpetual inventory method (PIM) which sums several years of capital formation and deducts assets that reached the end of their service life. Detailed series were compiled of acquisitions and sales of capital assets in eight different parts of transport, showing for each a breakdown into infrastructure, transport equipment, and other machinery and equipment.

In various parts of transport, producers increasingly lease or rent transport equipment instead of buying them. In air transport for example, in 1998 more than 80 per cent of the new aircraft were leased. For the purpose of productivity analysis, capital stock estimates should include not only owned assets, but also those which are rented and leased for more than one year. However, national accounting conventions imply that the PIM frequently fails to include non-owned assets. In the branches where leased and rented transport equipment were the most common, e.g. air and maritime transport, registers were used instead of the PIM as the former allows to account for non-owned assets.

In the second part of the paper productivity results are presented. Labour, capital and total factor productivity is estimated using the Tövrnqvist discrete approximation to the Divisia index. Between 1970 and 1997, labour productivity grew fastest in air and maritime transport. On the contrary, trucking, urban and interurban passenger transport, and transport services performed poorly. In the 1970s and the 1990s, capital productivity fell in 
all branches except air and maritime transport. In the 1980s, all branches showed minor capital productivity gains. Air and maritime transport also showed the best TFP performance. In the past decades, the good performance in air transport was accompanied by an increase in capital services and employment. In maritime transport, on the contrary, labour and capital inputs fell sharply.

The variance of productivity patterns across transport sectors found in France was not unique, as illustrated by a comparison with Germany, the United Kingdom and the United States. Overall productivity gains in the Germany and the United Kingdom were similar to those in France. The three European countries outperformed the USA. At the sectoral level, it turns out that air transport was the branch with the highest growth rates of capital productivity in all countries. The USA was the only country with large productivity gains in railways. France outperformed other countries in terms of productivity growth in air and maritime transport. In the other branches, productivity growth in France was below that of the other countries.

JEL Classification : D24, L91

Keywords : Transport, Capital Stock, Total factor productivity, France, International comparisons. 


\section{RÉSUMÉ}

L'efficacité des producteurs de services est souvent approchée par la productivité du travail. Cette mesure, partielle, est alors considérée comme un bon indicateur de l'efficacité globale des prestataires dans la mesure où de nombreux services utilisent relativement peu de capital. Cependant, dans certaines activités de services, tels que les transports, le capital est un facteur de production essentiel. En conséquence, juger de l'efficacité globale dans ces services suppose de compléter les mesures de productivité du travail par celles relatives au capital et à la productivité globale des facteurs. En France, la productivité du capital et la productivité globale des facteurs ne peuvent être estimées pour chacun des secteurs de transport en raison de l'indisponibilité d'estimations du capital utilisé dans la production.

L'objectif du présent travail est de combler ce déficit en proposant de nouvelles estimations détaillées du facteur capital mobilisé dans la production des services de transports en France. Ces données sont exploitées, en association avec des statistiques relatives aux productions et au facteur travail, afin d'estimer les productivités. Enfin, les résultats enregistrés par la France sont confrontés avec ceux des mêmes activités en Allemagne, au Royaume-Uni et aux Etats-Unis.

A la différence de plusieurs autres études sur la productivité, la contribution du capital à la production n'est pas ici mesurée à partir de la valeur du stock des actifs mais par le volume de services rendus par ce stock. En d'autres termes, la méthode mise en oevre est celle de Jorgenson et ses collaborateurs. Un inconvénient majeur du recours aux stocks de capital - brut ou net - en vue d'une analyse des productivités réside dans le fait que toutes les autres variables sont des flux : valeur ajoutée, consommations intermédiaires et heures travaillées. Certes, les changements dans le stock brut ou net, peuvent être vus comme des flux, mais ce sont alors des flux de premier ordre alors que les changements dans les autres variables sont des flux de second ordre. Afin d'étudier la productivité, l'intérêt se porte donc non pas sur le stock de capital mais sur les services rendus par ledit stock de capital. Les services du capital sont mesurés par le produit entre du volume de capital, approché par le stock de capital net et son coût d'utilisation. Ce dernier étant estimé à partir de la somme des dépréciations, le taux d'intérêt réel et les gains du capital.

Les enquêtes directes sont les voies préférables pour mesurer les stocks nets de capital. Cependant, à la différence par exemple des Pays-Bas, de telles enquêtes ne sont pas conduites en France. La meilleure approche est alors de recourir à la méthode de l'inventaire permanent qui a pour principe d'additionner plusieurs années de formation de capital et de déduire les actifs ayant atteint la fin de leur durée de vie. Dans le cadre de la présente étude, sont utilisées les statistiques relatives aux investissements et aux déclassements de huit catégories différentes d'activités de services. Pour chacune d'elles, une désagrégation entre les infrastructures, les équipements de transports et les autres machines et équipements est pratiquée. 
Toutefois, la méthode de l'inventaire permanent produit des résultats avec des biais dans les secteurs caractérisés par une proportion importante de rotation des actifs de capital et par un taux élevé d'actifs loués ou en crédit bail. Dans diverses activités de transports les producteurs utilisent de plus en plus de capitaux loués ou en crédit au lieu de les acquérir. Par exemple, en 1988, plus de 80 pour cent des nouveaux avions entrant dans le stock du secteur des transports aériens étaient des actifs en crédit bail. En conséquence, étudier la productivité suppose d'estimer le stock de capital comprenant non seulement les actifs possédés mais également ceux qui sont loués ou en crédit bail. Pour ce faire, une autre méthode a été utilisée dans les transports maritime et surtout aérien, c'est-à-dire les branches où les actifs loués et en crédit bail sont les plus importants.

Les résultats relatifs aux productivités obtenus sont présentés dans le deuxième partie du travail. La productivité globale des facteurs est estimée à partir des indices Tövrnqvist. Au cours de la période sous étude, à savoir 1970 - 1997, la productivité du travail s'est accrue plus vite dans les secteurs maritime et aérien. A l'opposé, le transport routier de marchandises, le transport urbain et interurbain de passagers et les services annexes aux transports montrent des résultats beaucoup plus modestes. Dans toutes les branches, à l'exception du maritime et de l'aérien, la productivité du capital enregistre une tendance à la baisse sur toute la période même si les années quatre-vingt sont marquées par une légère croissance. Les activités de transports aérien et maritime ont également les meilleures performances dans la productivité globale des facteurs.

La diversité de l'évolution des productivités entre les secteurs constatée dans le cas de la France, ne lui est pas spécifique ainsi que le montre les comparaisons avec l'Allemagne, le Royaume-Uni et les Etats-Unis. En effet, s'il est vrai que les gains de productivité globaux dans les deux autres pays européens, sont similaires à ceux de la France, il est vrai également que le transport aérien y apparaît comme le secteur avec les plus grands gains de productivité. Les pays européens ont en général des résultats supérieurs à ceux des EtatsUnis, où le transport ferroviaire est celui avec les gains de productivité les plus élevés. La France enregistre ses meilleures performances relatives en termes de croissance de productivité dans les transports aérien et maritime.

Classification JEL : D24, L91.

Mots clés : Transport, stock de capital, productivité total des facteurs, France, comparaisons internationales. 


\section{ACKNOWLEDGEMENTS}

We are grateful to the Ministry of Transport (Ministère de l'Equipement, des Transports et du Logement) for the financial support of this study. This study could not have been realised without the help of many persons to construct detailed long term series on capital formation. In particular we thank Philippe Poudevigne (Department of Statistics and Studies of the Ministry of Transport) for his great help in finding statistics, for establishing contacts, and for his comments. We thank Mary O'Mahony for her extensive advice during the various stages of this research: on locating former studies in this area, on the construction of series of capital stocks and capital services, and on the methodology of productivity calculations. The comments of Angus Maddison, Marie-Claire Grima and participants of the third meeting of the Canberra Group in Washington DC (8-10 November 1999), and the conference «Economie et Socio-Economie des Services » in Roubaix (22-23 June 2000) were also very helpful. We thank Laure Boivin for her excellent secretarial assistance. Finally, we are also grateful to the following persons for data collection:

Mr. Baratin (Bureau des investissements, Département contrôle de gestion et finances, Régie Autonome de Transport Parisien, RATP),

Mrs. Bernard (Comité Central des Armateurs de France),

J.F. Boyer (Direction du transport maritime des ports et du littoral, Ministère des transports),

M.A. Cambois (Pole information de gestion, Société Nationale des Chemins de Fer, SNCF),

G. Brilhault, A. Greliche and J. Bournay (Institut National des Statistiques et Etudes Economiques),

J.P. Combelles (Airclaims France),

J.P. Chonavel, (Communication financière, Direction financière, Air France),

Mrs. Cohen, (Société Nationale des Chemins de Fer),

Mr. Fedorovsky (Chambre Syndicale des Constructeurs de Navires),

Y. Puibarreau (Contrôle de gestion, Département contrôle de gestion et finances, Réseau Autonome de Transport Parisien),

Mrs. Rooste (Institut du Transport Aérien),

Mr. Roublot (Recherches et études, Barry Rogliano Salles),

J.C. Rozner (Secrétaire général, Comité Central des Armateurs de France),

P. Tellier (Département des finances, Aéroports De Paris),

P. Villa (CEPII). 





\title{
Capital Stock And Productivity in French Transport: AN INTERNATIONAL COMPARISON
}

\author{
Bernard Chane Kune and Nanno Mulder ${ }^{1}$
}

\section{INTRODUCTION}

Until the late 1980s, many parts of French transport operated in a relatively protected environment, as they were either state-owned or/and they were sheltered against competition from foreign firms. The competitive environment has substantially changed over the past decade, as state-owned enterprises were (partly) privatised and foreign firms were increasingly allowed to compete with French transport firms. Under these new circumstances, the French firms are under a much stronger pressure to increase their performances, of which productivity is an essential part.

The efficiency of transport firms is often approximated by labour productivity. This partial measure is considered as a proxy of overall efficiency as many services use relatively little capital. However, in many services such as transport, capital is a major production factor. To judge the overall efficiency of these services, labour productivity measures should therefore be complemented by measures of capital and total factor productivity (TFP). For France, to date capital productivity and TFP could not be estimated for individual branches of transport as no capital input estimates were available at this level.

This paper aims to fill this gap by providing new detailed estimates of capital input in French transport from 1970 onwards. Ideally the way to measure net capital stocks is by comprehensive direct surveys. Contrary to for example the Netherlands, no such surveys exist in France. The second best method, also used in this study, is the perpetual inventory method (PIM) which sums several years of capital formation and deducts assets that reached the end of their service life. Detailed series were compiled of acquisitions and sales of capital assets in eight different parts of transport, showing for each a breakdown into infrastructure, transport equipment, and other machinery and equipment. In addition to the PIM, we also used administrative records to measure the stock of aircraft and maritime vessels. These records were used instead of the PIM as the only the former allows to take fully account of non-owned, i.e. leased and long term rented, assets.

The capital input data are used in combination with series on output and labour input to estimate productivity. The comparison of the productivity performances between branches fails to account for the fact that technological progress, and as a result productivity gains, strongly differ between sectors of transport. Therefore, we also compared France with three other countries, Germany, the UK and the USA, in order to confront the French performance in a particular transport sector with that of comparable countries.

\footnotetext{
${ }^{1}$ Nanno Mulder is Economist at CEPII. Bernard Chane-Kune is Associated Researcher.
} 
This paper is organised as follows. Section one presents an overview of the different measures and methods of capital input, of which the perpetual inventory method (PIM) and registers are retained for this study. For the PIM, special attention is paid to the measurement of service lives, retirement and depreciation patterns, the estimation of the benchmark stock, as well as the treatment of leased and rented assets. Section two deals with the measurement of capital formation and capital stocks in France using the PIM. The measurement of the stock of aircraft in France using administrative records is presented in section three. Section four combines the results for France with those of Germany, the United Kingdom and the United States to measure labour, capital and total factor productivity, followed by a conclusion.

\section{Measures And Measurement of Capital}

\subsection{The Scope of Gross Fixed Capital Formation}

The scope of data on capital formation is sometimes very narrow (see for example the Australian Bureau of Industry Economics, 1995c) and limited to fixed capital goods, whereas official recommendations such as the System of National Accounts ${ }^{2}$ include a much wider range of assets, such as natural resources and intangible capital such as patents, purchased goodwill and computer software. In this study, we adopted the definition of gross capital formation of FIXED ASSETS of the System of National Accounts (1993): the value of acquired assets by resident production units used at least for one year in the production process; as well as incorporated goods and services in existing fixed capital goods. Excluded from capital formation are expenses related to research and development and marketing. Three major categories of fixed capital goods can be distinguished: (a) residential structures such as houses and apartment buildings, and non-residential structures such as office and apartment buildings and infrastructure; (b) machinery and (transport) equipment; (c) miscellaneous investments such as:

- goods and services incorporated in capital goods aimed to lengthen the asset life or improve the productive capacity of the assets such as major maintenance. Current maintenance is excluded from investment and included in intermediate expenses.

- additions to the existing capital goods resulting from mergers and acquisitions of firms;

- expenses linked to the acquisition of capital goods, such a notary costs and value added $\operatorname{tax}(\mathrm{VAT})$

- intangible fixed assets such as computer software (excluding research and development).

\subsection{Measures and Methods}

\subsubsection{The Contribution of Capital to Production: Stocks or Services}

\footnotetext{
${ }^{2}$ A manual aimed at harmonising the construction of national accounts prepared by a working group of various international organisations such as the United Nations, Eurostat and OECD.
} 
A controversial issue in the national accounts and productivity analysis is whether the contribution of capital stock to production is best measured by the gross stock, the net stock or by the services rendered by the capital stock. The gross stock equals the value of all fixed assets in use evaluated as if they were new, i.e. without taking account of obsolescence, depreciation, deterioration and price changes. The gross stock concept has been used in prior studies on productivity which assumed that the productive capacity of assets remains constant over time. This seems realistic for some goods such as computers. However, the productive capacity of most assets decreases over time and so gross stock may not be a very useful concept. At best the gross stock is an intermediate statistical measure which is used to estimate net capital stocks. Gross stocks can be measured by either physical measures, administrative records and the perpetual inventory method (PIM).

The net capital stock equals the gross stock less depreciation or the decline in value of the assets as they age. Net stocks can be estimated by either balance sheets or the PIM.

A disadvantage of using (gross or net) capital stocks for productivity analysis is that all other variables (such as value added, intermediate consumption and hours worked) are flows. The dimensions of the variables are therefore inconsistent. Productivity analysis focuses on changes in output and changes in inputs. Changes in gross or net stocks may be viewed as flows, but in fact these are first-order flows, as they indicate changes in stocks, whereas the others variables are of the second-order indicating changes inflows. Instead of stocks, we should use the second-order flow concept of services rendered by the capital stock to production.

\subsubsection{How to Measure Capital Stocks and Services?}

\section{Physical Measures}

Gross capital stock can be approximated by physical measures. For example in transport, one could use the length of canals, the number of ports and airports, the surface of office buildings and the number of trucks and buses. Data on physical measures are often readily available in most countries. For historical analyses, especially in the pre World War II period, capital formation data are also often restricted to physical measures.

The major inconvenience of physical measures is that they are not additive and it is therefore impossible to estimate aggregate capital stocks. Moreover, physical measures do not allow the distinction between different vintages, each having a different technology, within a capital stock. Therefore one has to assume that all capital goods are strictly identical in terms of productive capacity. This seems very unrealistic. 


\section{Administrative Records}

Another way to estimate gross stocks is the use of administrative records. In many countries records exist of most types of transport equipment such as aircraft, buses, ships, and trucks. These records can be used to measure the stock in one year as well as flows of investment and discards. In combination with data on asset prices, the build year of assets and price deflators, the value of gross stocks can be estimated.

\section{Balance Sheets}

Balance sheets are frequently used to estimate the value of net stocks as they register assets on a net basis. For corporate firms, these are readily available. Unfortunately balance sheets have various disadvantages which render their use almost impossible. Firstly, companies register assets at their historical values which means that the capital stock is valued at a mixture of prices. Moreover, depreciation is estimated using fiscal accounting principles. Fiscal depreciation rates are generally larger than economic depreciation rates. This means that even though the residual value of assets equals zero according to tax authorities, assets continue to be used in production. Moreover, accounting rules vary from country to country and net stocks on this basis therefore are not internationally comparable. From balance sheets it is also difficult to know the vintages of which the capital stock is composed.

\section{Surveys}

Questionnaires can be used to ask firms to report historic values of their assets and the dates when they were installed. Assets are subsequently re-valued to constant prices using revaluation coefficients. An advantage of surveys, contrary to other methods, is the possibility of including leased assets. The reliability of the surveys depends on the quality of the survey procedures and the ability of firms to supply the necessary information.

Within the OECD, surveys are used in Japan, Korea and the Netherlands. In the latter country, representatives of the statistical office visit firms as mail questionnaires give little satisfactory results. Due to the high costs of this method, the survey is carried out only once every five years. Stocks in intermediate years are estimated using the PIM. Often large discrepancies were found between PIM projections and survey results. These inconsistencies are interpreted as shortcomings of PIM and in particular the adopted asset live assumptions. However, the survey method is not without problems either, as firms often do not register small amounts of investments, alterations to existing assets, and whether the assets are new or second hand.

\section{Perpetual Inventory Method}

As the most relevant concept for productivity analysis is the net capital stock, physical measures and administrative records are unsuitable as they allow only the evaluation of the gross stock. Values listed on balance sheets are a net measure, but also unsuitable for the reasons outlined above. The best measurement method is therefore direct surveys. However, in most countries, such as France, these surveys are not carried out. As a second-best solution the "perpetual inventory method" (PIM) is used. The PIM sums 
several years of investment and deducts assets that have reached the end of their service life.

The PIM has been developed by Raymond Goldsmith (1951) in the United States. It has subsequently been used by growth accountants such as Simon Kuznets (1957), Edward Denison (1967) and Angus Maddison. In France, this method has been introduced by Jacques Mairesse at the INSEE in the early 1970s (see Mairesse, 1972).

The PIM has several advantages. Firstly, the PIM requires investment data which are more easily available than capital stock data. Secondly, the PIM produces many characteristics on capital stocks, such as gross stocks, capital consumption, net stocks and the average age of capital assets. Thirdly, the PIM is simple to apply and is fully transparent. Finally, identical retirement and depreciation patterns render capital stocks internationally comparable.

A major inconvenience is that the application of the PIM requires various assumptions on the length of asset lives, retirement and depreciation patterns which are often not very robust. Moreover, the PIM produces biased stock estimates when firms sell investment goods before they reach the end of their service life. This occurs often in the case of transport equipment. To account for this, Gillen et al. (1985), INSEE (1994) and O'Mahony (1999) propose to use real net (e.g. investment minus the sale of assets ${ }^{3}$ ) instead of gross investment series. A drawback of this method is that the price deflator used for sold assets differs from the deflator used for the initial investments, which may bias the results. Moreover, the value of the assets sold corresponds to the second-hand market value which differs from the economic value of the asset as estimated by the PIM.

Below the PIM is explained in more detail.

\section{Capital Services Approach}

Many growth accountants such as Edward Denison and Angus Maddison have assumed that services are proportional to the size of the capital stock. This is not realistic. A possible solution is the use of the depreciation instead of the capital stock. This is insufficient as it leaves out the net return of capital assets ${ }^{4}$. The best-known approach that

\footnotetext{
${ }^{3}$ The sale of assets before they reached the end of the asset life is also referred to as disposals.

${ }^{4}$ The value of an asset equals the sum of services rendered over its expected service life (assuming a scrap value equal zero): $V_{t}=\sum_{t}^{T} \frac{f_{t}}{(1+r)^{t}} ;(1)$, where $V_{t}$ equals the value of the asset; $f$ are the capital services of each period from t to T; service flows are discounted by the interest rate $r$; (1) can be rewritten as $V_{t}=\frac{f_{t}}{(1+r)}+\frac{f_{t+1}}{(1+r)^{2}}++\frac{f_{T}}{(1+r)^{T}}(2) . \quad$ The value of $V_{t}$ in the next period equals $V_{t+1}=\frac{f_{t+1}}{(1+r)}+\frac{f_{t+2}}{(1+r)^{2}}++\frac{f_{T}}{(1+r)^{T-1}}$ (3). Dividing $\quad$ (3) by $\quad$ (1+r) gives: $\frac{V_{t+1}}{(1+r)}=\frac{f_{t+1}}{(1+r)^{2}}+\frac{f_{t+2}}{(1+r)^{3}}++\frac{f_{T}}{(1+r)^{T}}$ (4). Subtracting (4) from (2): $V_{t}=\frac{V_{t+1}}{(1+r)}=\frac{f_{t}}{(1+r)}$ equals
} 
uses capital services to measure the contribution to production is that used by Jorgenson and his collaborators, which is outlined below. He measures the volume of capital services using the net capital stock as estimated by the PIM.

\subsection{Perpetual Inventory Method}

The PIM is one of the most frequently used methods to estimate capital stocks, e.g. the summing of several years of investments and the deduction of investments that have been discarded:

$$
K_{t}=\sum_{\tau=0}^{s} d_{\tau} I_{t-\tau}
$$

where $K_{t}$ equals the capital stock at year $t ; I_{t}$ investment at year $t$; and $d_{\tau}$ is the relative efficiency weight (e.g. the combination of retirements and depreciation) attached to each year's investment and $s$ the maximum service life. The application of PIM requires assumptions on service lives, retirement and depreciation patterns. The literature often distinguishes between gross and net stocks. The gross stock equals the sum of past investments still in existence and does not account for depreciation, i.e. the loss of productive value due to use, obsolescence, damage and ageing. For the gross stock, the age composition of the stock is irrelevant as each asset is supposed to have the same productive capacity. The net stock equals the gross stock minus the value of depreciation on the vintages in the gross stock. Assumed retirement and depreciation patterns strongly differ across studies, as discussed below.

\subsubsection{Service lives}

The economic service life is the period an asset is used in production. Technical progress or changes in fiscal laws may induce firms to withdraw an asset from production before it is technically worn out. This means that the economic service life is below the technical one. Assumptions on service lives strongly differ between OECD countries, as illustrated by Tables 1.A to 1.D. In the 1980 version of the French national accounts, assumed asset lives only varied between assets, e.g. 13 years for machinery and equipment and 40 years for buildings and other structures, but not across sectors. France adopted shorter service lives than Australia and the UK, but longer ones than Belgium.

Studies on transport often assume different service lives than national accounts. For aircraft in Canada, Gillen et al. (1985) assumed an asset life of fifteen years compared to ten years by Statistics Canada. For infrastructure in French railways, canals and ports, Quinet et al. (1994) also suggest longer service lives than INSEE.

\footnotetext{
$f_{t}=V_{t}-V_{t+1}+r V_{t}$ (6) Since $V_{t}-V_{t+1} \equiv D_{t}$ (depreciation in year $t$ ); (6) can be rewritten as $f_{t}=\left(d_{t}+r\right) V_{t}$.
} 


\subsubsection{Retirement patterns}

The decline in the productive capacity of an asset when it ages is described by retirement or decay patterns. A capital asset may require more inputs when it ages without losing its productive capacity (input decay). It is also possible that the volume of productive services produced decreases over time (output decay). Some studies assume that capital goods suffer neither from input nor from output decay. The retirement of these assets follows a so-called one-hoss shay pattern. The asset is scrapped completely at the end of its service life.

More often assets are not retired instantaneously but instead some are withdrawn before and some after the average service life. This is especially the case for heterogeneous asset categories. To spread discards, formula (1) (O'Mahony, 1999) can be rewritten to:

$$
K_{t}=\sum_{\tau=0}^{s+m+1} I_{t-\tau}+\sum_{s+m}^{s-m} d_{\tau} I_{t-\tau}
$$

Several patterns are used to spread discards. In France, the national accounts use lognormal functions as estimated by Mairesse (1972). These functions require assumptions on the average service life as well as the standard deviation. The US national: accounts (BEA,1993) used until recently adapted S-3 Winfrey ${ }^{5}$ curves for non-residential and residential capital. This curve follows a bell-shaped distribution centered on the average service life. For durable consumer goods, the BEA used the Winfrey L-2 curve, which is asymmetrical (e.g. large discards before the average service life and small ones

\footnotetext{
${ }^{5}$ Robley Winfrey, an engineer of the Iowa Engineering Experimentation Station, collected information on dates of installation and retirement of 176 groups of industrial assets during the 1930s. He calculated 18 "type" curves representing their retirement patterns. Winfrey curves are one of the few retirement patterns based on extensive empirical reasearch.
} 
Table 1.A: Average service lives of machinery and equipment (excluding vehicles) (years)

\begin{tabular}{|c|c|c|c|c|c|c|c|c|c|c|c|}
\hline & Canada & $\begin{array}{l}\text { United } \\
\text { States }\end{array}$ & Japan & Australia & Belgium & France & Germany & Iceland & Norway & Sweden & $\begin{array}{c}\text { United } \\
\text { Kingdom }\end{array}$ \\
\hline Railways & 28 & 27 & - & 30 & 15 & 13 & 23 & - & 12 & 35 & 25 \\
\hline Road: passenger & 10 & 15 & - & - & 15 & 13 & 11 & - & 15 & - & 25 \\
\hline Road: freight & 10 & 11 & - & - & 15 & 13 & 11 & - & 15 & - & 25 \\
\hline Air: aircraft & 10 & 16 & - & 18 & 15 & 13 & 11 & 14 & 15 & - & 8 \\
\hline Air: airports etc. & 10 & - & - & 18 & 15 & 13 & 11 & - & - & - & 15 \\
\hline Water: vessels & 35 & 27 & - & 19 & 15 & 13 & 21 & - & 17 & - & 10 \\
\hline $\begin{array}{l}\text { Water: harbours, } \\
\text { docks, canals }\end{array}$ & - & - & - & 19 & 15 & 13 & - & - & 25 & 40 & 25 \\
\hline Warehousing & 25 & 11 & 10 & - & 15 & 13 & - & - & 15 & - & 25 \\
\hline
\end{tabular}

Table 1.B: Average service lives of buildings and other construction separately (years)

\begin{tabular}{|c|c|c|c|c|c|c|c|c|c|c|c|}
\hline & \multicolumn{6}{|c|}{ Buildings } & \multicolumn{5}{|c|}{ Engineering construction } \\
\hline & Canada & $\begin{array}{l}\text { United } \\
\text { States }\end{array}$ & Finland & Italy & Norway & Sweden & Canada & $\begin{array}{l}\text { United } \\
\text { States }\end{array}$ & Finland & Norway & Sweden \\
\hline Railways & 50 & 47 & - & - & 75 & 80 & 55 & 51 & & 75 & 75 \\
\hline $\begin{array}{l}\text { Road: } \\
\text { passenger }\end{array}$ & 50 & 38 & - & - & - & 60 & 55 & 31 & & - & 80 \\
\hline Road: freight & 60 & 38 & - & - & - & 60 & 65 & 31 & & - & 80 \\
\hline Transport by air & 40 & 39 & - & - & 75 & 75 & 50 & 31 & & - & 80 \\
\hline $\begin{array}{l}\text { Transport by } \\
\text { water }\end{array}$ & 50 & 39 & - & - & - & - & 50 & 31 & & 75 & 80 \\
\hline Warehousing & 50 & 38 & - & - & - & - & - & 31 & & - & 80 \\
\hline
\end{tabular}


Table 1.C: Average service lives of buildings and other construction (years)

\begin{tabular}{|c|c|c|c|c|c|c|}
\hline & Australia & Belgium & Germany & France & Iceland & United Kingdom \\
\hline Railways & 67 & 30 & 41 & 40 & - & 100 \\
\hline Road: passenger & - & 30 & 43 & 40 & 75 & 50 \\
\hline Road: freight & - & 30 & 43 & 40 & 75 & 50 \\
\hline Transport by air & 32 & 30 & 43 & 40 & 75 & 40 \\
\hline Transport by water & 48 & 80 & 43 & 40 & 45 & 20 \\
\hline Warehousing & - & - & - & - & 45 & 50 \\
\hline
\end{tabular}

Table 1.D: Average service lives of other fixed assets (years)

\begin{tabular}{|c|c|c|c|c|c|c|c|c|c|c|}
\hline & Canada & United States & Belgium & Finland & France & Germany & Iceland & Norway & Sweden & United Kingdom \\
\hline Other ships & 35 & 27 & 15 & 10 & 22 & 26 & 37 & - & - & 20 \\
\hline Buses & 10 & 14 & 7 & 10 & 10 & 10 & 14 & 7 & 6 & 10 \\
\hline Rolling stock & 28 & 28 & 15 & 10 & 25 & 34 & 14 & 35 & 35 & 30 \\
\hline Road freight vehicles & 10 & 10 & 7 & 10 & 10 & 8 & 14 & 7 & 3 & 10 \\
\hline Aircraft & 10 & 16 & 15 & 10 & 16 & 10 & 14 & 15 & 15 & 10 \\
\hline
\end{tabular}

Source: OECD (1993) 
afterwards). In contrast the UK statistical office assumes a uniform distribution around the average service life.

\subsubsection{Depreciation patterns}

Depreciation is the decline in value of an asset as it ages. Financial depreciation refers to the decline in value whereas retirements (decay, discards) correspond to a fall in productive capacity. A number of different depreciation patterns have been used in the literature. The most common is straight-line depreciation corresponding to a smooth deterioration over the life of an asset, i.e. depreciation in the first year is the same as that in the second, which equals that in the third, etc.:

$$
\boldsymbol{\delta}_{s, S L}=\frac{1}{1-(s-1)}
$$

where $\delta_{, S L}$ is the straight-line depreciation rate and $s$ the asset life. The annual depreciation $d_{s, S L}$ equals:

$$
d_{s, S L}=1 / s
$$

The national accounts of various countries such as France have adopted linear depreciation.

Geometric deprecation is also frequently used, and is an accelerated pattern, i.e. the depreciation in the first year is higher than in the second year, which in turn is higher than that in the third, etc (Jorgenson, 1987, Hulten and Wykoff; 1981). The rate of depreciation $\delta_{\mathrm{G}}$ depends on the declining balance rate $\mathrm{R}$ and the asset's service life s:

$$
\delta_{G}=\frac{R}{S}
$$

$\delta_{G}$ is constant over the asset's lifetime. Depreciation $d_{s, G}$ equals:

$$
d_{s, G}=\delta_{G}\left(1-\delta_{G}\right)^{s-1}
$$

The higher is $R$, the higher the geometric rate of depreciation $\delta_{i}$, and the higher the depreciation in the early years of an asset's service life. The use of a declining balance rate equal to one is also referred to as the single declining balance method. Christensen and Jorgenson (1969) adopted the double declining balance method (e.g. $R=2$ ). The replacement rate equals $2 / \mathrm{s}$. 
A drawback of geometric depreciation is that after the end of the service life of an asset, a very small share (going to infinity) of the asset value remains in the stock. Some authors have redistributed this residual value over the depreciation in the earlier years so that the remaining value after the expiration of the service life equals zero. This solution was not adopted here, as it complicates the mathematics and the calculations. Moreover, the residual value is too small to bias the net stock estimates.

Several studies, cited by Fraumeni (1997), found that geometric depreciation corresponds closely to the evolution of prices of used assets. These studies, including some on transport equipment ${ }^{6}$, collected price data from second-hand markets, dealers, insurance records and rental companies. Another advantage of geometric depreciation is that is method is easily applicable (see O'Mahony, 1999). The relative efficiency function is $\mathrm{d}_{\tau}=\left(1-\delta_{G}\right)^{\tau}$. Substituting this in equation (1) gives:

$$
K_{t}=I_{t}+(1-\delta) K_{t-1}
$$

\subsubsection{Estimation of the Benchmark Stock}

The application of the PIM methodology is often limited by the availability of investment series. Data on capital formation do often not go back much further than the period for which one would like to estimate the capital stock. This complicates the measurement of the initial year stock using the PIM. Two alternatives are available to measure benchmark stocks, Firstly, book values of the capital stock, as derived from balance sheets, can be used. Harberger (1978) proposed another shortcut method which requires the average annual investment $I_{t}$ and GDP growth $\gamma$ over the period for which investment data are available, and an assumption on the depreciation rate $\delta$ Subsequently, the capital stock at the starting year $t$ is implicitly derived by:

$$
I_{\mathrm{t}}=(\delta+\gamma) K_{\mathrm{t}-1}
$$

\subsubsection{Treatment of leased and rented assets}

Since the 1970s, transport firms increasingly lease or rent capital assets instead of buying them. Often, like in the American national accounts, only owned assets are included in the capital stock. However, in productivity analysis all assets used in production should be considered including leases and long-term rentals. This practice was adopted by the British national accounts since 1987 as well as the French national accounts. For countries which adopted the principle of capital ownership like the United States, leased and rented assets can be transferred from the sector of ownership to the industry of use on the basis of assumptions on which sectors leased the assets (see O'Mahony, 19997).

\footnotetext{
${ }^{6}$ E.g. Hall (1971) and the Office of Tax Analysis (1991) on trucks and Cockburn and Frank (1992) on oil tankers.

${ }^{7}$ For example, she assumed for the USA that 80 per cent of aircraft and ships owned by the financial sector were leased to the transport sector and re-allocated them accordingly.
} 


\subsection{Capital Services Approach ${ }^{8}$}

This approach is an extension of the PIM. Its most well known proponent is Prof. Dale Jorgenson at Harvard University. The main difference is that according to the PIM the contribution of capital to production is best measured by the value of the stock, whereas according to Jorgenson it is not the stock itself, but the services rendered by the stock that matter. The advantage of measuring capital input by services instead of stocks is that the flow dimension of the former is coherent with the other variables in productivity analysis, i.e. gross output or value added, intermediate inputs and labour input.

Capital services have both a quantity and a price component. Ton kilometres provided by trucks or square meters of storage space provided by a warehouse are paid by a user cost or rental price of capital. Services of some capital goods, such as aircraft, buildings, cars, and trucks, are traded between asset owners and producers who need to use them on a lease market. However, most capital services are produced for own consumption and there is no explicit market transaction. In general it is not possible to observe quantities and prices of capital services. Capital differs in this respect from labour as for the latter the remuneration (market wages) can be observed. User costs represent the amount of rent charged in order to cover the cost of $q$ monetary units worth of assets.

Fortunately, economic theory (see Jorgenson and Griliches, 1967; Jorgenson et al., 1987; Hulten, 1990) provides the main elements of the user cost of capital:

- an internal rate of return, which is the value of an asset times a rate of return. The rate of return accounts for the opportunity cost of using capital elsewhere than in production. Opportunity costs and rates of return are equal in equilibrium;

- depreciation, represents the loss of value of an asset as it ages;

- capital gains or losses, i.e. the change in the value of an asset due to a increase or a decrease in the price of an asset which are unrelated to ageing. Capital gains or losses are measured by the change in the price of a new asset from $t$ to $t+1$.

In summary, the user cost of capital or service price $S_{t}$ is determined as follows:

$$
S_{t}=\left(\frac{1-u_{t} z_{t}-k_{t}}{1-u_{t}}\right)\left[q_{t-1} r_{t}+q_{t-1} d-\left(q_{t}-q_{t-1}\right)\right]+q_{t} T_{t}
$$

where:

$u_{t}=$ corporate tax rate at year $\mathrm{t}$

\footnotetext{
${ }^{8}$ The presentation of capital services is based on Jorgenson's joint 1969 article with Christensen, see also Gilles et al. (1985) and Jorgenson et al. (1987).
} 
$z_{t}=$ resent value of depreciation deductions for tax purposes on one currency unit's worth of investment over the life-year of the investment at year $\mathrm{t}$

$k_{t}=$ nvestment tax credit at year $\mathrm{t}$

$q_{t}=$ asset price index at year $\mathrm{t}$

$r_{t}=$ opportunity cost of capital at year $\mathrm{t}$

$d=$ depreciation rate of asset reflecting economic life

$T_{t}=$ property tax rate at year $\mathrm{t}$

The first term is brackets corresponds to the rate of return, the second to depreciation, and the third to the capital loss or gain of the asset. In summary, to determine the service price, one should take account of the corporate income tax, savings in corporate income tax due to capital cost allowances, investment tax credit, rate of return of the asset, economic depreciation, capital gains or losses due to asset price changes, and the property tax rate.

\subsection{Sectoral Studies}

\subsubsection{Specifics of Transport}

The transport sector differs from other sectors in several respects. Firstly, transport companies often sell transport equipment before their asset life ends. When this is not accounted for, the stock estimates overstate the true value of the stock. Secondly, a growing share of transport equipment is no longer owned by transport firms but leased or rented. If this is not considered, the capital stock used in production will be underestimated.

Currently a number of studies on the estimation of capital stocks in transport have been undertaken by researchers in Australia, Canada, the United States and France, as discussed below. Table 2 summarises these studies.

\subsubsection{The Canadian Centre for Transportation Studies}

Over the past two decades, the University of British Columbia's Centre for Transportation Studies has produced several studies dealing, amongst other issues, with the measurement of the capital stock in Canadian air and railway transport. The methodology used is based on Chistensen and Jorgenson (1969). Gillen et al.'s (1985) study on Canadian aviation distinguished eight types of capital assets. The volume of 
Table 2: Overview of Studies on Capital Formation and Capital Stocks in Transport

\begin{tabular}{|c|c|c|c|c|c|c|c|c|}
\hline Author & Countries & Sectoral detail & Types of assets & Period & M ethodology & R etirement pattern & $\begin{array}{l}\text { Depreciation } \\
\text { pattern }\end{array}$ & Remarks \\
\hline $\begin{array}{l}\text { Pereira da Silva } \\
\text { (198?) }\end{array}$ & France & $\begin{array}{l}\text { Total of transport } \\
\text { only }\end{array}$ & $\begin{array}{l}\text { Infrastructure and } \\
\text { transport equipment }\end{array}$ & $1959-1980$ & $\begin{array}{l}\text { Mairesse } \\
(1972)\end{array}$ & Log-normal function & $\begin{array}{l}\text { Linear } \\
\text { depreciation }\end{array}$ & \\
\hline Lorentz (1987) & France & $\begin{array}{l}\text { Routes, public } \\
\text { road passenger } \\
\text { transport, } \\
\text { railways, airlines, } \\
\text { airports, } \\
\text { waterways, and } \\
\text { ports }\end{array}$ & $\begin{array}{l}\text { Infrastructure and } \\
\text { transport equipment }\end{array}$ & $1971-85$ & -- & -- & -- & Investment only \\
\hline $\begin{array}{l}\text { Quinet et al. } \\
\text { (1994) }\end{array}$ & France & $\begin{array}{l}\text { Roads, railways, } \\
\text { urban passenger } \\
\text { transport, ports, } \\
\text { and canals }\end{array}$ & Infrastructure only & $\begin{array}{l}\text { Investment: } \\
1952-91 \text {; stock- } \\
1991 \text { only }\end{array}$ & $\begin{array}{l}\text { Log-normal } \\
\text { function }\end{array}$ & Log-normal function & $\begin{array}{l}\text { Linear } \\
\text { depreciation }\end{array}$ & \\
\hline $\begin{array}{l}\text { O’Mahony } \\
\text { (1999) }\end{array}$ & $\begin{array}{l}\text { France, } \\
\text { Germany, } \\
\text { Japan, UK } \\
\text { \& USA }\end{array}$ & $\begin{array}{l}\text { Railways, other } \\
\text { inland, water and } \\
\text { air; France \& } \\
\text { Japan: only } \\
\text { aggregate }\end{array}$ & $\begin{array}{l}\text { Non-Residential } \\
\text { structures, and } \\
\text { machinery and } \\
\text { equipment }\end{array}$ & $\begin{array}{l}\text { Investment and } \\
\text { Stock 1950-96 }\end{array}$ & $\begin{array}{l}\text { Fraumeni } \\
(1997), \\
\text { Jorgenson } \text { et } \\
\text { al. }(1987, \\
1989)\end{array}$ & $\begin{array}{l}\text { Spread over several years } \\
\text { (NOT "one-hoss shay") }\end{array}$ & $\begin{array}{l}\text { Geometric } \\
\text { decay }\end{array}$ & \\
\hline $\begin{array}{l}\text { Gillen et al. } \\
\text { (1985) }\end{array}$ & Canada & Airlines & Eight categories & $1963-81$ & $\begin{array}{l}\text { Jorgenson et } \\
\text { al (1969) }\end{array}$ & \multicolumn{2}{|c|}{$\begin{array}{l}\text { No distinction between gross and net stock; } \\
\text { single declining balance method }\end{array}$} & \\
\hline $\begin{array}{l}\text { Tretheway et al. } \\
\text { (1997) }\end{array}$ & Canada & Railways & $\begin{array}{l}\text { Three categories: way } \\
\text { and structures, } \\
\text { equipment and land }\end{array}$ & $1956-91$ & $\begin{array}{l}\text { Jorgenson } e t \\
\text { al (1969) }\end{array}$ & \multicolumn{2}{|l|}{ See Gillen et al. (1985) } & $\begin{array}{l}\text { Incorporation of rented } \\
\text { and leased capital }\end{array}$ \\
\hline $\begin{array}{l}\text { Hooper and } \\
\text { Hensher (1997) }\end{array}$ & Australia & Airports & Non-specified & $\begin{array}{l}1988 / 89- \\
1991 / 92\end{array}$ & PIM & Non-specified & Non-specified & $\begin{array}{l}\text { Unclear how PIM was } \\
\text { with four years of } \\
\text { investment }\end{array}$ \\
\hline $\begin{array}{l}\text { Bureau of } \\
\text { Industry }\end{array}$ & $\begin{array}{l}\text { Australia, } \\
\text { Canada, UK }\end{array}$ & $\begin{array}{l}\text { Road freight } \\
\text { transport }\end{array}$ & Trucks and trailers & 1992 & -- & $\begin{array}{l}\text { Trucks ( } 5 \text { years), trailers ( } 8 \\
\text { years); at the end of working }\end{array}$ & Straight-line & $\begin{array}{l}\text { This study only calculates } \\
\text { capital cost }=\text { depreciation }\end{array}$ \\
\hline
\end{tabular}


CEPII - Working Paper $n^{\circ}$ 00-18

\begin{tabular}{|c|c|c|c|c|c|c|c|}
\hline $\begin{array}{l}\text { Economics } \\
(1992)\end{array}$ & and USA & & & & $\begin{array}{l}\text { life residual value of } 21 \text { per } \\
\text { cent of initial purchase cost. }\end{array}$ & & $\begin{array}{l}\text { + opportunity cost of } 7 \\
\text { percent. }\end{array}$ \\
\hline $\begin{array}{l}\text { Bureau of } \\
\text { Industry } \\
\text { Economics } \\
(1992-1995)\end{array}$ & $\begin{array}{l}\text { Australia, } \\
\text { several } \\
\text { European } \\
\text { countries, } \\
\text { Canada USA }\end{array}$ & $\begin{array}{l}\text { Locomotives and freight wagons in } \\
\text { railways, vessels in coastal shipping, } \\
\text { cranes, berths and loaders in ports, aircraft } \\
\text { and seat kilometres in airlines, and runway } \\
\text { capacity and gates at airports. }\end{array}$ & $1992-1993$ & $\begin{array}{l}\text { Physical } \\
\text { measures only }\end{array}$ & \begin{tabular}{|l|}
- \\
\end{tabular} & -- & \\
\hline
\end{tabular}


capital services was calculated by the net stock (estimated by the PIM) times its user cost as derived by equation (9). For the estimation of user-costs, the authors used asset-specific data on depreciation, corporate and property tax rates, tax allowances for the deduction of depreciation, interest rates and the net appreciation of assets.

Tretheway et al. (1997) estimated the 1956-91 capital stock in railways using the same methodology as for aviation. The authors included owned and leased assets. They distinguished structures, equipment and land. As the productivity of land remains unchanged, depreciation was excluded from its user cost.

\subsubsection{The Australian Bureau of Industry Economics}

From 1992 to 1995, the Australian Bureau of Industry Economics (BIE) evaluated the performance of rail freight transport, coastal shipping, ports, airlines and airports as part of the project International Performance Indicators. For the measurement of capital productivity, the BIE relied mostly on physical measures of the capital stock: locomotives and freight wagons in railways, trucks and trailers in road freight transport, vessels in coastal shipping, cranes, berths and loaders in ports, aircraft and seat kilometres in airlines, and runway capacity and gates at airports. Though physical measures can be relatively easily observed, they can be poor measures of the true capital stock. Moreover, the capital stock in each branch encompasses many more assets than the ones considered by the BIE. In railways, for example, they omitted infrastructure. Physical measures are also unsuitable in estimating capital services.

\subsubsection{Capital Stock Estimates in American Transport}

The earliest estimates of the capital stock in US transport were made by Ulmer (1960). For the period 1870 to 1950 , he estimated stocks for steam railways, street and electric railways, local bus lines and other transport. The final category groups trucking, other motor vehicle transportation, pipelines, water transport, air transport, and transport services. The 1870 stocks were based on book values. Subsequent years were estimated by adding net capital expenditures to the 1870 stock values. Net capital expenditures equalled gross capital expenditures less capital consumption. Gross capital expenditures include investment expenditure, excluding land but including organisation cost, taxes and legal expenses. Capital consumption equals retirements and depreciation. Ulmer did not provide separate estimates for the two but combined them in one estimate of straight-line depreciation.

The country with the most detailed capital accounts since the 1950s is the USA. The BEA $(1993,1999)$ provides investment and capital stocks for more than sixty branches. For seven branches in transport, the BEA provides a breakdown by six types of transport equipment and five types of non-residential structures. Investment starts in 1929 and stocks in 1947. The 1947 benchmark stocks are based on Ulmer (1960). Until 1997, the BEA estimated gross and net stocks using the PIM. The BEA assumed that retirements were spread according to Winfrey curves and that depreciation was linear. Since the 1997 
revision, the retirement and depreciation functions were merged into a combined function of geometric decay and the BEA no longer publishes gross stocks (see Fraumeni, 1997).

\section{CAPITAL Formation and CAPITAl StOCK IN FrEnCh Transport}

\subsection{Delimitation of the transport sector}

The transport sector includes many activities, of which the boundaries according to the industrial classifications vary from one country to another. For example, public urban passenger transport is included in transport in most European countries whereas in the USA it is part of the government sector. Sector classifications also classify differently supporting services: Canada and the USA consider airports and ports as part of air and maritime transport respectively, whereas in France these are part of a separate category "supporting services to transport". As this study focuses on France, we adopted the French Industrial Classification (Nomenclature des activités et des produits, NAP) to define the boundaries and sectoral breakdown of transport. ${ }^{9}$ The French national accounts provide a breakdown into seven sectors (see Appendix 1), even though the NAP is more detailed. For these seven sectors, consistent series on GDP and employment from 1970 onwards are available. For our international comparisons, inland water and maritime transport, as well as road freight transport, road passenger transport and transport services, had to be merged due to a lack of detail in other countries.

Roads, bridges and tunnels are excluded from capital formation in transport, as they are part of capital formation of the central and local governments.

\subsection{Sources of Gross Fixed Capital Formation and Capital Stocks}

\subsubsection{National and Satellite Accounts}

The French national accounts, produced by INSEE, publish sectoral capital stock estimates since the early 1970 s as pioneered by Mairesse (1972). He presents gross and net capital stock estimates of Non-residential structures and machinery and equipment for 21 sectors for the period 1950-70. No breakdown for transport is provided. Retirements were spread over several years using a log-normal function ${ }^{10}$ and depreciation was assumed to be linear. ${ }^{11}$ The 1980 revision of the national accounts presently in use in France presents

\footnotetext{
${ }^{9}$ The NAF replaced the NAP (Nomenclature d'activite et de produit) only in the mid 1990s. Long run series are only available in the NAP nomenclature.

${ }^{10}$ For a given year $n$, and an investment $I$ with age of $p$ years, the retirement $S B(n)$ equals $S B(n)=\sum_{p=0}^{n} I(n-p) f(p)$ and the gross stock $C B(n)$ equals $C B(n)=\sum_{p=0}^{n} I(n-p)\left[1-\sum_{q=0}^{p} f(p)\right]$.

${ }^{11}$ The depreciation $A(n)$ in year $n$ equals $A(n)=\sum_{p=0}^{n} I(n-p) g(p)$ and the net stock $\mathrm{C} N(n)$ equals $C N(n)=\sum_{p=0}^{n} I(n-p)\left[1-\sum_{q=0}^{p} g(p)\right]$.
} 
capital formation by total transport and by government firms in transport [SNCF (railways), RATP (passenger transport in Paris and surroundings), and Air France and Air Inter (air transport)]. From 1970 to 1977 , the only asset breakdown available is non-residential structures and machinery and equipment. Since 1977, more detail is provided into 17 asset types. These series are available both at constant and current prices. Currently the INSEE is changing its series and base year to 1995 . These new results will become available early 2001 .

Another series on investment and disposals is provided by the satellite accounts on transport which are jointly produced by INSEE and the Ministry of Transport since the early 1950s. These accounts provide a breakdown into seven sectors for the 1970s and into six sectors (excluding urban and interurban passenger transport) from 1980 onwards. Before 1970 only partial information is available on investment in railways, road freight transport (vehicles only) and road passenger transport. Since 1980 information is also provided on public investment in infrastructure (railways, urban passenger transport, ports, airports, inland water transport). The satellite accounts also provide series on GDP at constant and current prices, employment and hours worked by sub-sector since 1970 .

\subsubsection{Firm Data}

For the four largest transport firms (SNCF, RATP, Air France, Air Inter), long run investment series were partly derived from company data. The company data of RATP listed in its annual reports are close to those of INSEE. However, this is not the case for the SNCF as the INSEE data are 30 per cent higher than those of the SNCF. The SNCF underestimated investment as they excluded leased equipment and major maintenance. Air France and Air Inter did also excluded leased equipment from their investment figures.

\subsubsection{Annual Firm Survey (EAE)}

Since the early 1970s, the Ministry of Transport surveys investment undertaken by transport firms annually. This survey presents a breakdown into 18 transport sectors and covers almost the entire sector except railways (included only since 1993) and several transport services. The Enquête annuelle d'entreprise shows five types of assets and distinguishes purchases of new and used capital goods. For firms with less than five employees, the only available asset breakdown is transport equipment and other investments. The investment data refer to total acquisitions meaning that disposals have not been deducted. Only the total of disposals is provided by the EAE, without an asset breakdown. It is therefore impossible to derive gross fixed capital formation (e.g. acquisitions less disposals) by asset type.

The EAE and the satellite accounts investment data show important discrepancies. Moreover, the EAE series show major breaks. These discrepancies and breaks originate from frequent changes in sample methods and coverage of the EAE survey. The EAE data are therefore inadequate to construct long run series. However, they were used to disaggregate total investment data of the satellite accounts by asset type. 


\subsubsection{Administrative Records}

The perpetual inventory method yields biased capital stock estimates in sectors which sell most assets before their service life ended, and in industries that rely heavily on leased and rented capital. This is because gross fixed capital formation, which is the main ingredient to the PIM, does not correctly measure discards and rented and leased assets are only partially taken into account.

Air and maritime transport are characterised by a high turnover of their transport equipment. Moreover, these activities rely heavily on leased and rented capital. In these sectors, administrative registers of capital assets were used instead of the PIM. These records permit coherent estimates of capital formation, gross and net stocks, independently of whether assets are owned or not.

\subsubsection{Studies on Capital Formation}

In France, few studies are available on investment and capital stock in transport covering the period before 1970. Villa (1993) estimated gross fixed capital formation in nonresidential structures on the one hand and machinery and equipment on the other in transport (and other sectors) from 1870 onwards. His major source is the Annuaire Statistique de la France of INSEE. Toutain (1967) estimated investment at current prices in railways in the nineteenth and first half of the twentieth century. For other sectors, only physical measures of the capital stock are available, such as the length of canals and roads in use and the number of aircraft, ships, and vehicles.

Several studies exist on investment and capital stocks in transport in recent decades. Lorentz (1987) evaluated investment in transport in the period 1971-86. He distinguished infrastructure and transport equipment in public transport activities, and private ports, highways, airports, ports and maritime transport. To convert the series at current prices to constant 1985 prices, he used a single price deflator for capital formation by the French (local and federal) government. The data sources are well documented. He made no capital stock estimates.

Quinet, Roy, Schwartz and Taroux (1994) measure the gross and net stocks of parts of the transport infrastructure (roads, railways, urban passenger transport, ports, and canals) in 1991. They apply the perpetual inventory method by accumulating investments at constant prices from 1950 onwards. The investment series at current prices for all branches were deflated by using the same price index as Lorentz (1987). It is, however, quite unlikely that price increases were the same for all types of infrastructure. The Mairesse (1972) methodology is used to estimate retirements and depreciation. The asset life for each group of assets was estimated as a weighted average of its components. For example, the asset life of non-residential structures in railways is a weighted average of the lives of buildings, surfaces, tracks, electrical wire, signalling equipment and miscellaneous structures.

The construction of series of gross fixed capital formation at current prices on the basis of the sources mentioned above is discussed in detail in Appendix B. For the SNCF 
and RATP, series start in 1946 and 1950 respectively. For road freight transport, urban and interurban passenger transport (except RATP), inland water transport and transport services, series were constructed back to the early 1950s. Series only start in the 1960s for maritime and air transport. Three asset types are distinguished in this study: non-residential investment (mostly buildings and transport infrastructure), transport equipment, and other machinery and equipment.

A summary of statistical sources on gross fixed capital formation and capital stocks in transport is given in Table 3.

The deflators for the 1970-97 period were extrapolated backwards to 1959 using capital formation deflators for the total economy provided by INSEE. These are broken down by infrastructure, road and rail transport equipment, aircraft and ships, and other machinery and equipment. Finally, the 1959 deflators were extrapolated to earlier years using the deflators used by O'Mahony (1999) which distinguish between infrastructure on the one hand and transport and other equipment on the other.

\subsection{Measurement of Gross Stocks}

Two methods are used to estimate gross stocks. Administrative records were used to measure the stock of transport equipment in air and maritime transport (see section 3). For all other assets and sectors, we adopted the perpetual inventory method. The PIM requires assumptions on asset lives and retirement patterns. For France, estimates are available only by large groups of asset types but not by sub-sector of transport. Instead we used detailed assumptions by asset type of the Department of Commerce, Bureau of Economic Analysis (1999). These are based on a large body of empirical research and are summarised in Fraumeni (1997). The specific asset-life assumptions were converted to sector-specific asset lives using detailed investment data by sector and asset for the United States (see O'Mahony, 1999). Non-residential structures, transport equipment, and other machinery and equipment consist each of several asset types. Non-residential structures comprise different types of buildings (commercial, industrial, etc.), but also pipelines, railway structures and railway replacement track. Transport equipment distinguishes aircraft, cars, ships, tractors and trucks and buses. The other machinery and equipment category includes communication equipment, different types of computer and office 
Table 3: Statistical Sources on Gross Fixed Capital Formation in Transport

\begin{tabular}{|c|c|c|c|c|}
\hline Source & Sectoral Detail & Asset Breakdown & Period & Comments \\
\hline Mairesse (1972) & Total transport only & NRS and ME only & $1950-70$ & Constant prices \\
\hline INSEE (annually) & $\begin{array}{l}\text { Total transport, SNCF, RATP, Air France, Air } \\
\text { Inter }\end{array}$ & $\begin{array}{l}\text { Two types until 1977, } 17 \\
\text { types since } 1977\end{array}$ & 1970-97 & Both constant and current prices \\
\hline $\begin{array}{l}\text { INSEE/ Ministry of } \\
\text { Transport (SES) } \\
\text { (annually) }\end{array}$ & $\begin{array}{l}\text { Total transport, SNCF, RATP, Air France, Air } \\
\text { Inter, road freight transport, inland water } \\
\text { transport, maritime transport, air transport }\end{array}$ & no & 1970-97 & $\begin{array}{l}\text { Current prices only; urban and interurban pas-senger } \\
\text { transport excluded }\end{array}$ \\
\hline $\begin{array}{l}\text { INSEE/ Ministry of } \\
\text { Transport (SES) } \\
\text { (annually) }\end{array}$ & $\begin{array}{l}\text { Railways, urban passenger transport, ports, } \\
\text { airports, inland water transport }\end{array}$ & Public infrastructure only & 1980-97 & Current prices only \\
\hline $\begin{array}{l}\text { Ministry of } \\
\text { Transport-Annual } \\
\text { Enterprise Survey } \\
\text { (EAE) (annually) }\end{array}$ & $\begin{array}{l}\text { Very detailed breakdown into } 18 \text { sectors; } \\
\text { railways and taxis are included since 1993; few } \\
\text { transport services are included }\end{array}$ & $\begin{array}{l}\text { Seven types (new and used } \\
\text { transport equipment, new } \\
\text { and used equipment, land, } \\
\text { office buildings and other } \\
\text { investements) }\end{array}$ & 1972-97 & $\begin{array}{l}\text { Current prices only; series show major breaks due to } \\
\text { changes in coverage and sampling methods }\end{array}$ \\
\hline $\begin{array}{l}\text { Firm data } \\
\text { (annually) }\end{array}$ & SNCF, RATP, Air France, Air Inter & $\begin{array}{l}\text { Between four and ten types } \\
\text { of capital assets }\end{array}$ & $\begin{array}{l}\text { From } 1950 \text { or } \\
1970 \text { onwards }\end{array}$ & $\begin{array}{l}\text { Current prices; little information on rented and } \\
\text { leased capital and disposals }\end{array}$ \\
\hline Toutain (1967) & Railways & Total only & $1846-1950$ & Current prices \\
\hline Lorentz (1987) & $\begin{array}{l}\text { Railways, urban passenger transport, inland } \\
\text { water transport, maritime transport, air } \\
\text { transport, airports, ports, private highways }\end{array}$ & $\begin{array}{l}\text { Two types only: } \\
\text { infrastructure and transport } \\
\text { equipment }\end{array}$ & 1971-86 & Both and constant and current prices \\
\hline $\begin{array}{l}\text { Quinet et al. } \\
\text { (1994) }\end{array}$ & $\begin{array}{l}\text { Railways, urban passenger transport, ports, and } \\
\text { canals }\end{array}$ & Infrastructure only & $\begin{array}{l}\text { Starting between } \\
1948 \text { to } 1970 \\
\text { end } 1991\end{array}$ & Both and constant and current prices \\
\hline Airclaims & Air transport & Aircraft only & 1960-97 & Stock data \\
\hline
\end{tabular}


Capital Stock and Productivity in French Transport : An International Comparison 
equipment, furniture and fixtures. Asset lives for the three asset categories within each sector were calculated as a weighted average. Suppose transport equipment $T$ in sector $J$ is composed of $i$ types of assets, and let $A$ equal the asset life for asset $i$. Then the asset life $A$ for transport equipment $T$ in sector $J$ is given by:

$$
A_{T J}=\sum s_{i j} A_{i j}
$$

where $s_{i j}=I_{i j} / \sum I_{i j}$ is the share of asset $i$ in total real transport equipment investment. The average investment shares for non-residential structures were estimated for the period 1950-97, and for transport equipment and other machinery and equipment for the period 1970-97. The results of the weighting procedures show that asset lives of nonresidential structures and other machinery and equipment are similar across sectors. In contrast, service lives of transport equipment are very different across sectors because of the varying composition of this asset group by sector as well as the large differences in service lives of components: trucks (10 years) are the largest part of transport equipment in road goods transport whereas rolling stock (28 years) is the main asset in railways. Our estimates are similar to those of O'Mahony, as the same method and data were used (see Table 4). Small differences are due to the use of US data up to 1994 by O'Mahony and 1997 in this study. The supposed service lives by INSEE, which will be adopted in a new series of wealth estimates to be published in 2000, are considerably longer for non-residential structures (60 years), and somewhat shorter for transport (15 years) and other types of equipment (13 years). Retirements were spread over several years around the average service life of an asset category, as illustrated by formulae (2) of Section 1.

Table 4: Asset Live Assumptions in Transport

\begin{tabular}{|c|c|c|c|c|c|}
\hline \multirow[b]{2}{*}{ Sector } & \multicolumn{3}{|c|}{ This Study } & \multicolumn{2}{|c|}{ O'Mahony (1998) } \\
\hline & $\begin{array}{c}\text { Non- } \\
\text { residential } \\
\text { structures }\end{array}$ & $\begin{array}{l}\text { Transport } \\
\text { equipment }\end{array}$ & $\begin{array}{c}\text { Other } \\
\text { machinery } \\
\text { and equipment }\end{array}$ & $\begin{array}{c}\text { Non- } \\
\text { residential } \\
\text { structures }\end{array}$ & $\begin{array}{l}\text { Transport } \\
\text { and other } \\
\text { equipment }\end{array}$ \\
\hline Railways & 45 & 27 & 16 & 45 & 23 \\
\hline $\begin{array}{l}\text { Road passenger } \\
\text { transport }\end{array}$ & 40 & 16 & 14 & \multirow{2}{*}{38} & \multirow{2}{*}{14} \\
\hline $\begin{array}{l}\text { Road goods } \\
\text { transport }\end{array}$ & 38 & 10 & 14 & & \\
\hline Water transport & 39 & 26 & 13 & 38 & 24 \\
\hline Air transport & 39 & 20 & 13 & 39 & 15 \\
\hline Transport services & 36 & 25 & 12 & 39 & 12 \\
\hline TOTAL & 42 & 17 & 14 & 43 & 17 \\
\hline
\end{tabular}

Source: Dept. of Commerce, Bureau of Economic Analysis (1999) and O’Mahony (1998).

Gross capital stocks are thus obtained by summing gross fixed capital formation over the life of assets. The major results, in terms of the sectoral composition of capital stocks, 
are presented in Figure 1. Railways and transport services (among which airports, ports, toll highways) account for the largest part of the gross capital stock of infrastructure (see panel A). Their shares changed little over time. The share of RATP has risen and that of air transport declined somewhat over the past decades. The composition of the stock of transport equipment changed radically with rising shares of air transport and trucking and declining shares of maritime and inland water transport (see Panel B). The stock of other equipment is dominated by railways; airlines is the only branch that increased its share.

\subsection{Measurement of Net Stocks}

Net stocks take account of the wear and tear of use over the live of an asset. They equal gross stocks minus depreciation. Among the large variety of depreciation functions, the one retained here is geometric depreciation, as presented by formula (7) in Section 1. As no detailed data are available on depreciation patterns of assets in French transport, detailed depreciation rates provided by Hulten and Wykoff (1981) and Fraumeni (1997) were transformed into sectoral depreciation rates in the same way as was done to estimate sectoral service lives. For this purpose, $A_{i j}$ was replaced in formula (8) by asset specific depreciation rates $D_{i j}$. The depreciation rates by sector and asset group used here are similar to those of O'Mahony (1999) as illustrated in Table 5.

Table 5: Geometric Depreciation Rates in Transport

\begin{tabular}{lccccccc}
\hline \multirow{2}{*}{ Sector } & \multicolumn{3}{c}{ This study } & & \multicolumn{2}{c}{ O'Mahony (1999) } \\
\cline { 2 - 3 } & $\begin{array}{c}\text { Non- } \\
\text { residential } \\
\text { structures }\end{array}$ & $\begin{array}{c}\text { Transport } \\
\text { equipment }\end{array}$ & $\begin{array}{c}\text { Other } \\
\text { machinery } \\
\text { and equipment }\end{array}$ & & $\begin{array}{c}\text { Non- } \\
\text { residential } \\
\text { structures }\end{array}$ & $\begin{array}{c}\text { Transport } \\
\text { and other } \\
\text { Equipment }\end{array}$ \\
${$\cline { 1 - 2 }$} }$ & 0,0229 & 0,0523 & 0,1134 & & 0,0228 & 0,144 \\
Road passenger & 0,0238 & 0,1120 & 0,1225 & & & \\
transports & & & & & 0,0242 & 0,144 \\
Road goods transports & 0,0240 & 0,1716 & 0,1207 & & & \\
Water transport & 0,0239 & 0,0638 & 0,1437 & & 0,0248 & 0,078 \\
Air transport & 0,0238 & 0,0817 & 0,1220 & & 0,0234 & 0,135 \\
Transport services & 0,0250 & 0,0564 & 0,1300 & & 0,0237 & 0,158 \\
TOTAL & 0,0235 & 0,0481 & 0,1213 & & 0,0261 & 0,134 \\
\hline
\end{tabular}

Source: Dept. of Commerce, Bureau of Economic Analysis (1999) and O’Mahony (1999).

The composition of net stocks is similar to that of the gross stocks for all three groups of assets, as illustrated by Figure 2. This is because depreciation rates are not very different between branches for one capital good. However, this is not the case for transport equipment: the depreciation rate of railways was less than a third of that of trucking. The share of trucking in the net stock is therefore smaller than in the gross stock and that of railways larger. 
Figure 1: Gross Stock Composition: Infrastructure (Panel A), Transport Equipment (Panel B) and Other Equipment (Panel C)
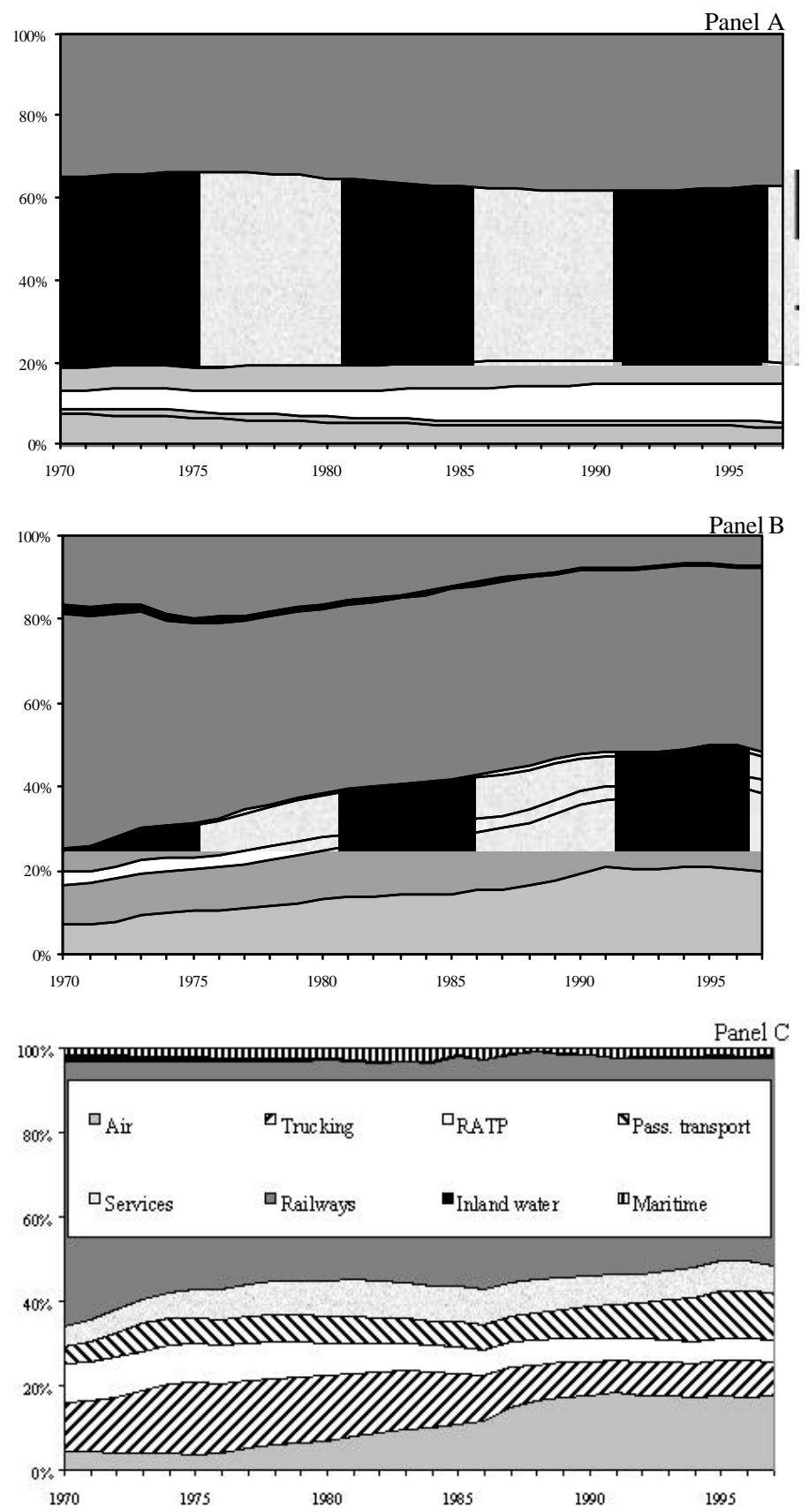

Sources: See Annex D. 
Figure 2: Net Stock Composition: Infrastructure (Panel A), Transport Equipment (Panel B) and Other Equipment (Panel C)
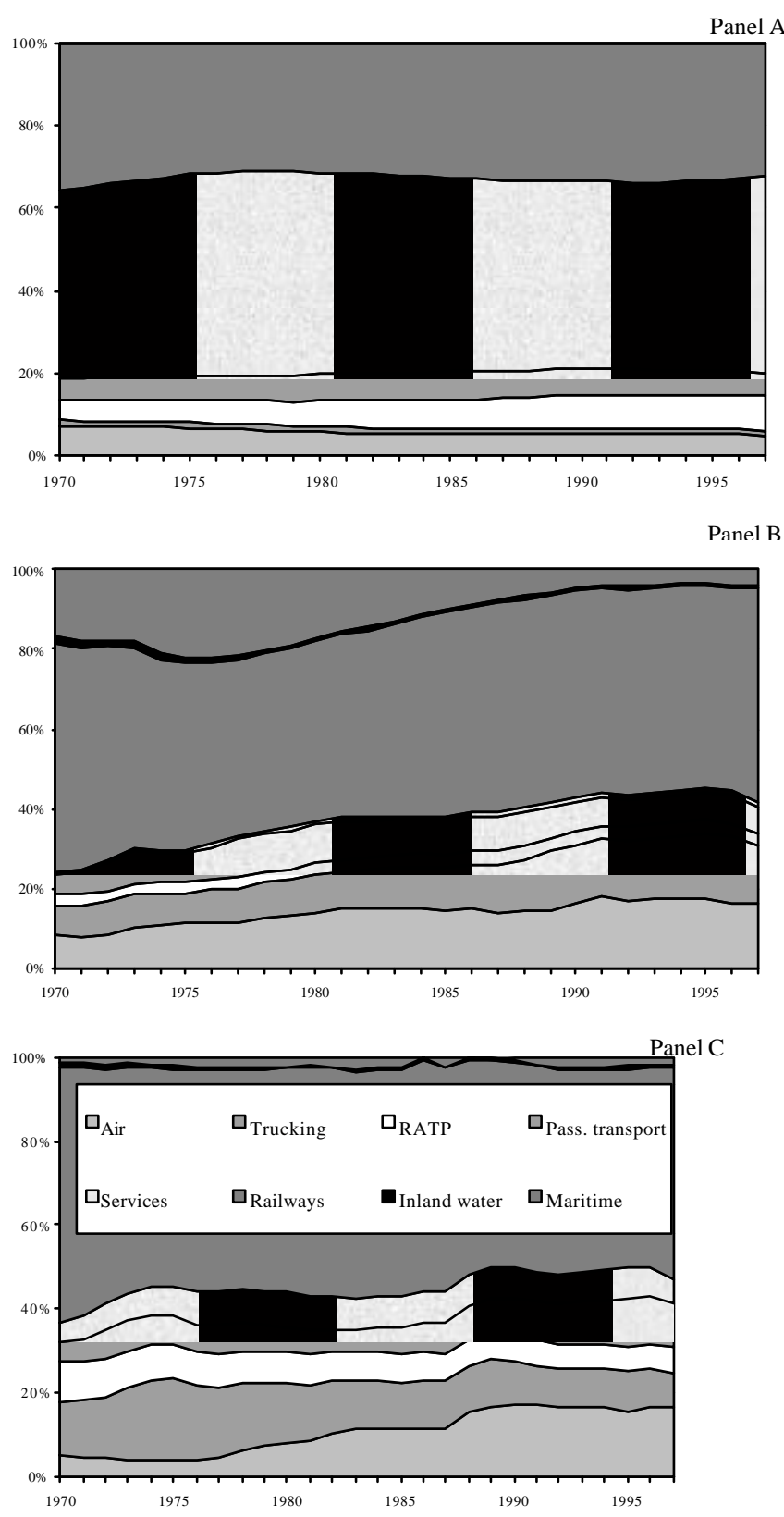

Sources: See Annex D 


\subsection{Measurement of Capital Services}

Capital services equal the volume of capital services, approximated by the net capital stock, times the user cost of capital. The latter are estimated by a simplified version of formula (9), following O'Mahony (1999):

$$
\mathrm{S}_{\mathrm{t}}=\left[\mathrm{q}_{\mathrm{t}-1} \mathrm{r}_{\mathrm{t}}+\mathrm{q}_{\mathrm{t}-1} \mathrm{~d}-\left(\mathrm{q}_{\mathrm{t}}-\mathrm{q}_{\mathrm{t}-1}\right)\right]
$$

The user cost $S_{t}$ thus equals the real interest rate as a proxy of the rate of return $\left(q_{t-1} r_{t}\right)$ plus depreciation $\left(q_{t-1} d\right)$ minus real capital gains $\left(q_{t}-q_{t-1}\right)$. For various countries during several periods, such as France in the 1970s, the use of real interest rates leads to negative user costs as these rates were highly negative. As negative user costs are unrealistic, other proxies should be used which provide more plausible estimates of the rate of return on capital. These proxies are often based on complex indirect estimation methods and are little robust (see Harper et al., 1989). As this issue is beyond the scope of this paper, we have, as O'Mahony (1999), assumed a real interest rate of 5 per cent for all countries and all sectors. Real capital gains are estimated by the increase in the price of asset $i$ minus the price increase of all assets.

For individual assets, the growth rate of capital services is the same as that of the net capital stock. This is not the case for the total capital stock, as the net stock of nonresidential structures is weighted by its user cost, as well as the net stock of transport equipment and other machinery and equipment. For the total transport sector, the use of capital services instead of the gross or net stocks does not yield very different growth rates (see Figure 3). However, at the level of branches, capital services grew at a slower pace particularly in Parisian passenger transport (RATP) and to a lesser extent in maritime transport. The result for the RATP is explained by the large investments in infrastructure. These have long asset lives and therefore low depreciation rates. The growth of capital stocks depends on new investment, while the growth of capital services is largely determined by depreciation rates. As the former was relatively high, the capital stock grew fast, but since depreciation rates are low capital services grew more slowly.

When most investment is in only one type of capital, the growth of capital services largely coincides with that of the net capital stock. This was the case in transport services and air transport, which invested mostly in non-residential structures and aircraft respectively. 
Figure 3: Indices of Gross Capital Stock, Net Capital Stock, Capital Services (1970=100)

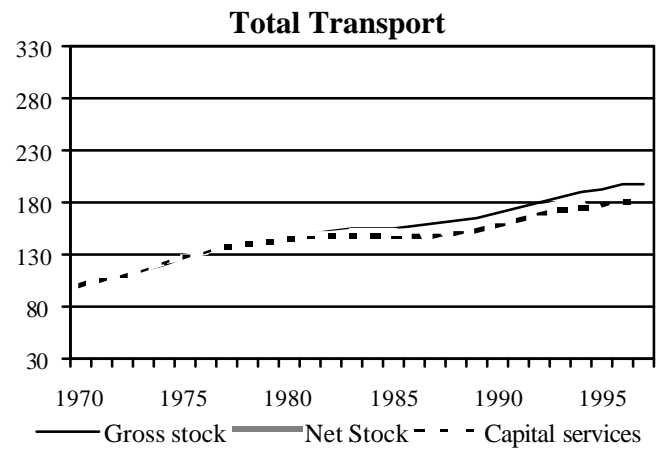

Sources: See Annex D, see text for derivation capital services.

From 1970 to 1997, capital input grew most rapidly in the RATP, followed by road freight transport. The largest decline in capital services occurred in inland water and maritime transport. The latter result should be interpreted with care, as the stock of capital decreased less than shown in Figure 4. The large fall in the stocks and services of owned ships was partly compensated by an increase in the use of ships under flags of convenience and leases. Due to data constraints, these were excluded from the capital stock and services estimates of this study.

\section{The Aircraft Stock Measured by Administrative ReCordS}

\subsection{Introduction}

The perpetual inventory method produces biased capital stock measures in sectors characterised by a large turnover of capital assets and important shares of leased and rented assets. When administrative records are available for capital assets, these biases can be corrected as illustrated in this Section for the stock of aircraft. Registers were also used to measure the stock of vessels in maritime transport, see Annex B for more details.

This section concentrates on the measurement of capital stocks, even though, as with most national accounts and productivity analysts, we agree that it is capital services what we are really interested in. We focus nevertheless on stocks because they are an important element in the estimation of capital services. Errors in the measurement of the capital stock will bias the estimate of capital services. 
Figure 4: Indices of Gross Capital Stock, Net Capital Stock, Capital Services (1970=100)
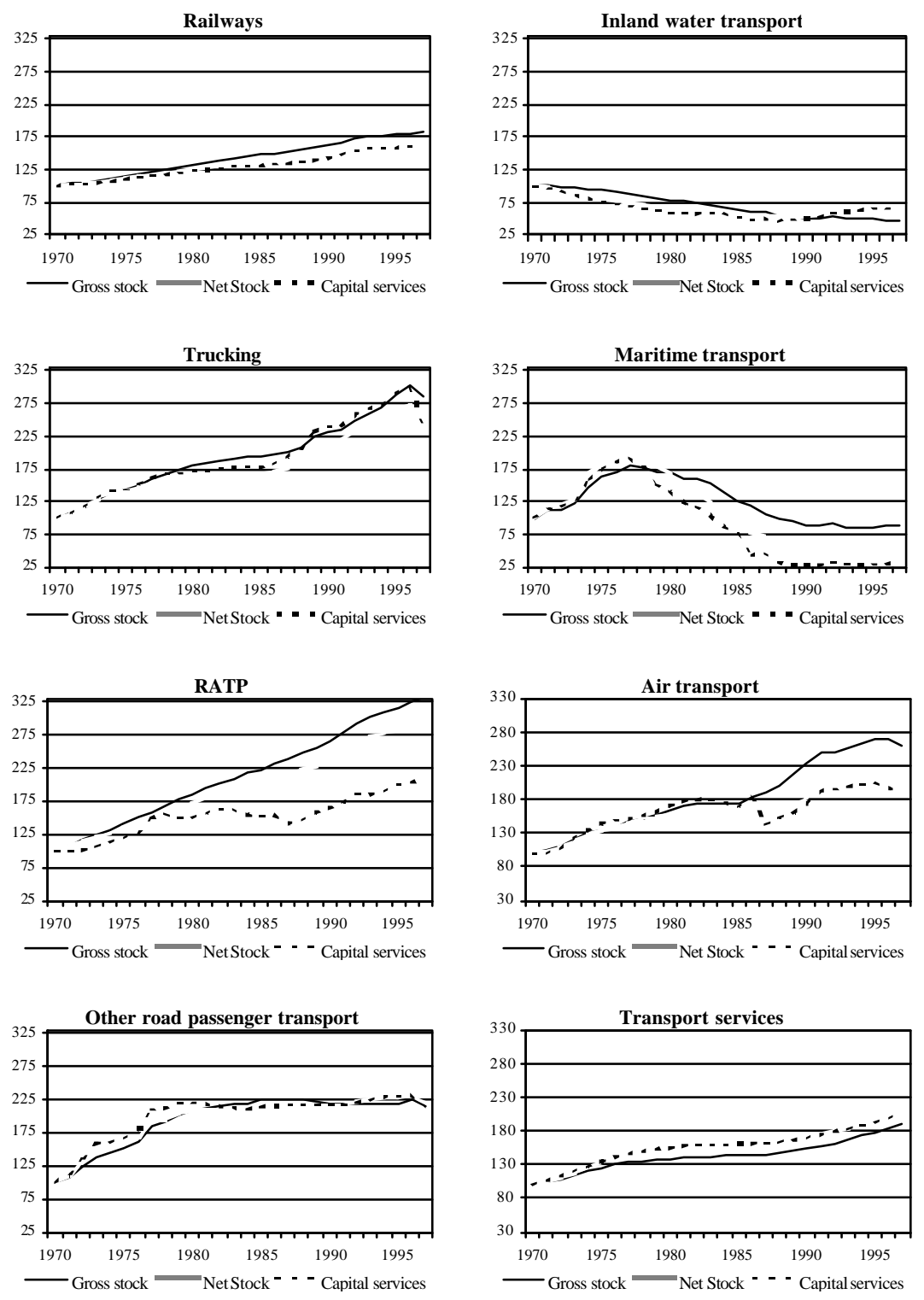

Sources: See Annex D, see text for derivation capital services. 


\subsection{Treatment of Discards and Disposals}

Discards (also referred to in the literature as retirements or scrapping) are assets withdrawn from production. When service lives are estimated correctly, assets are removed from the capital stock at or around the end of their service life. Their residual value thus equals zero. Discards are different from disposals, as the latter are sales of assets to other producers who continue to use them. Disposals have a value above zero and are supposed to be removed from the capital stock before their service life ends. Firms sell these asset at the prevailing second-hand prices, which, in principle, correspond to the net value, e.g. the constant replacement value ${ }^{12}$ minus depreciation.

In the standard PIM approach, they are deducted from acquisitions to estimate gross fixed capital formation (GFCF). The latter should not to be confused with net fixed capital formation which equals GFCF minus depreciation. The measurement of GFCF poses several problems. Firstly, assets older than their service life may be sold while according to the PIM they have a zero value. The second-hand value of these assets is deducted from acquisitions. This is inconsistent with the PIM, and GFCF is thus underestimated.

Secondly, the concept of GFCF is not consistent with the concept of gross capital stocks. This is because acquisitions and disposals are valued at their second-hand value, which takes account of depreciation, instead of at their constant replacement value. GFCF may also be biased for the measurement of net stocks when second-hand prices, used to estimate the value of disposals and second-hand goods entering the capital stock, substantially differ from the net value of assets as estimated by the PIM methodology.

To resolve these biases detailed information is required on the age of assets, the years when they enter and leave the stock and their constant replacement value. For a coherent application of PIM it would be useful to distinguish between two types of GFCF: nondepreciated and depreciated GFCF. Non-depreciated GFCF measures acquisitions and disposals at their constant replacement value and is consistent with the gross stock concept. Depreciated GFCF, calculated by the depreciated values of acquisitions and disposals, is consistent with the net stock concept. In practice it is difficult to estimate both types of GFCF as often only aggregate data are available of the value of acquisitions and disposals without information on the build year, entry, exit and replacement value of each asset. In many cases only data on GFCF is available without a distinction between acquisitions and disposals. Nevertheless, for some assets, such as aircraft, administrative records and prices are available, and the above mentioned biases can be eliminated, as discussed below.

\footnotetext{
${ }^{12}$ The constant replacement price equals the historical price of the asset revalued to the prices of a selected year (1980 in this study).
} 


\subsection{Treatment of Leased and Rented Assets}

Another difficulty in capital stock estimation is the treatment of leased and rented assets. One difficulty is whether leased assets should be attributed to the owner or the user industry. Another is the measurement of the gross and net stocks, and capital services of leased assets.

Rented assets are classified to owners instead of users in the capital stocks estimates of the national accounts of most countries. However, for productivity and other types of analyses it is necessary to estimate the total capital stock used in production. These should include assets leased and rented for at least a year. In various industries, such as air transport, long term rentals are increasingly common. The omission of these assets leads to an underestimation of the available capital stock.

In this paper, we focus on leased assets as they are more common than long term rentals.

\subsubsection{Allocation of Leased Assets}

The allocation of leased assets depends on the type of analysis. For profitability analysis, it is preferable to allocate them to the owner industry, whereas for productivity analysis assets are attributed to user industries. The practice of the national accounts also differs between OECD countries which complicates international comparisons. The French national accounts and the System of National Accounts manual-1993 (paragraphs 13.23 and 13.24) attribute leased assets to the capital formation of the user. The US national accounts, on the contrary, consider leases as part of the owner industry. As we aim to estimate the capital stock used in production, we attributed assets to the user industries.

\subsubsection{Measurement of the Leased Capital Stock using the PIM}

Including leased assets in the capital stock of the user-industry is difficult as in most countries only data on leasing cost are available. The major part of these costs correspond to the cost of capital, but they also include financing and storage cost. Leasing cost can be used to measure capital services but not to measure capital stocks. In order to estimate the stock of leased assets of the user industry, it is necessary to reallocate capital formation or the value of the stock from the owner to the user industry. This is sometimes done on the basis of arbitrary rules. For example, O'Mahony (1999) re-classified the largest part of investment in aircraft from the financial sector to air transport. She supposed that 20 per cent of aircraft was for own-use while the rest was leased to air transport. 
In France, the national accounts attribute leased assets to the user industry on the basis of annual surveys. These show the domestic suppliers and domestic users of leased capital. The value of an investment equals the sum of future payments plus the specified value at which the user buys the asset at the end of the lease (as specified in the lease contract). An inconsistency in the French national accounts is that these end values are double counted: once in the year the lease contract is signed and once again in the year when the lease expires and the firms acquires the asset. This is because INSEE cannot separate purchases of leased assets from other acquired assets. Another shortcoming of the INSEE data is that they only cover assets leased from domestic firms and exclude assets leased from foreign companies. ${ }^{13}$

\subsection{Using Administrative Records to Measure Gross and Net Capital Stocks}

The use of the PIM leads to biased results for the measurement of the capital stock in industries which are characterised by frequent disposals and large shares of leased and rented assets for the reasons outlined above. Air transport is an example of such an industry. International competition forces air companies to regularly update their fleet and therefore they sell most of their aircraft long before the end of their service life. Moreover, instead of purchasing, companies increasingly lease or rent their aircraft. The importance of disposals, leases and rentals is difficult to assess with aggregate data on gross fixed capital formation as they are net flows and do not separate acquisitions and disposals. Moreover, even when rented and leased assets are included, they cannot be isolated within the acquisitions.

Instead, administrative records provide many characteristics as they present information on each asset. As such, they show when assets enter and leave the capital stock, when the asset was built and whether it is owned or not by the operator. In this study, the administrative records of aircraft are taken from the Airclaims database. Airclaims is one of the major insurance companies of aircraft. Their monthly updated database contains data on the stock of aircraft of most countries in the world starting in the 1950s. It presents detailed information of all aircraft operated by resident companies of each country, including those leased and rented from domestic and foreign firms.

The Airclaims database provides no data on (historical) construction cost. These were mostly taken instead from the Airliner Price Guide which contains prices paid by the first purchaser of each type of aircraft in US\$. After the conversion to French francs, these historical cost data were deflated to constant prices using the French deflator of aircraft in capital formation of the transport sector. ${ }^{14}$

\footnotetext{
${ }^{13}$ For Air France and Air Inter, INSEE included foreign leases in the GFCF as they had access to company accounts showing both domestic and foreign lease contracts. This was impossible for other private firms in air transport.

${ }^{14}$ Annex B provides more details on the construction of the aircraft stock on the basis of registers.
} 
Robust estimates of the gross stocks can be made with the register data. This is because, contrary to the PIM, no assumptions are necessary on the length of asset life and retirement patterns, as the registers shows exactly when asset enter and leave the stock. Net stocks are more relevant than gross stocks, as the value of aircraft within the fleet also diminishes over time. Moreover, not all aircraft are new when they enter the fleet. The estimation of net stocks is more difficult than gross stock as little, easily exploitable, information is available of how the market price of particular aircraft develop over time. Assumptions have to be made on depreciation patterns. The evolution of second-hand prices of transport equipment follows a geometric pattern, as illustrated by Fraumeni (1997). We did however not use this pattern, as the register data exclude an important element of capital formation in aircraft, e.g. major maintenance and revision. Therefore the net value of the aircraft is underestimated over its life time. To compensate for this, we assumed straight-line instead of geometric depreciation, which produces smaller reductions in the constant replacement value during the early life of the aircraft.

\subsubsection{Gross Fixed Capital Formation}

In the literature, gross fixed capital formation is defined by acquisitions less disposals of assets. Both acquisitions and disposals are valued at market prices. In combination with the PIM, these series of capital formation are used to estimate both gross and net capital stocks. However, as pointed out above, this concept is unsuitable to measure gross stocks as depreciation is deducted from the constant replacement value of acquisitions and disposals.

To assess the impact of this bias on the gross stock estimates, we constructed two series of capital formation: one compatible with the estimation of gross stocks, referred to as non-depreciated GFCF, and one adapted to estimate net stocks, referred to as depreciated GFCF. The former values all assets at their constant replacement value, whereas the latter takes account of depreciation.

Paradoxically, non-depreciated GFCF is frequently below depreciated GFCF. The easiest way to understand this it to analyse the two components of GFCF, e.g. acquisitions and disposals. Depreciated values of disposals - compared to constant replacement values are relatively lower than depreciated values of acquisitions, as the former are mostly older than the latter. This is illustrated in Figures 5-a and 5-b, which show the ratio of the depreciated to the constant replacement values of assets. Going from depreciated to nondepreciated values, the proportional increase in the value of disposals is bigger than that in acquisitions. As disposals are deducted from acquisitions to calculate GFCF, nondepreciated GFCF is lower than depreciated GFCF. ${ }^{15}$

\footnotetext{
${ }^{15}$ The following example helps to understand the paradox. Suppose that in year $t$ a firm acquires an asset of two years old with a constant replacement value of 100 and a depreciated value of 80 . The same year the firm sells an asset of eight years old with a constant replacement value of 70 and a depreciated value of 10. Going from depreciated to non-depreciated values, the proportional increase in the value of disposals (70/10) is much more than that in acquisitions (20/80). As disposals are deducted from acquisitions to calculate GFCF, non-depreciated GFCF (e.g. 10) is lower the depreciated GFCF (70).
} 
Figure 5: Ratio of Depreciated to Constant Replacement Values, 1980 prices

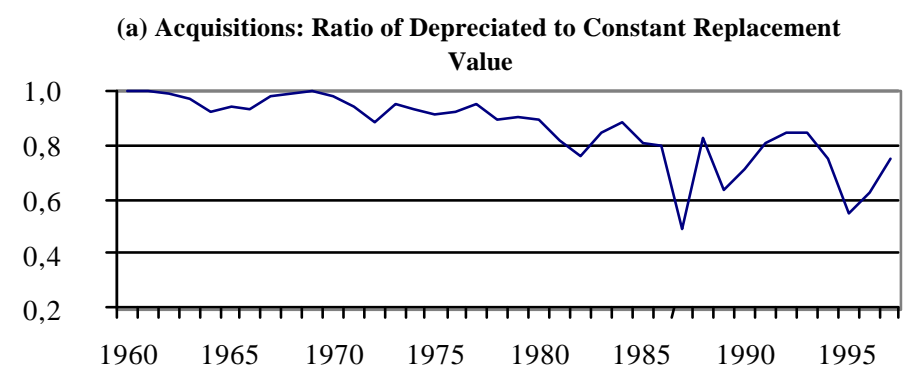

(b) Disposals: Ratio of Depreciated to Constant Replacement

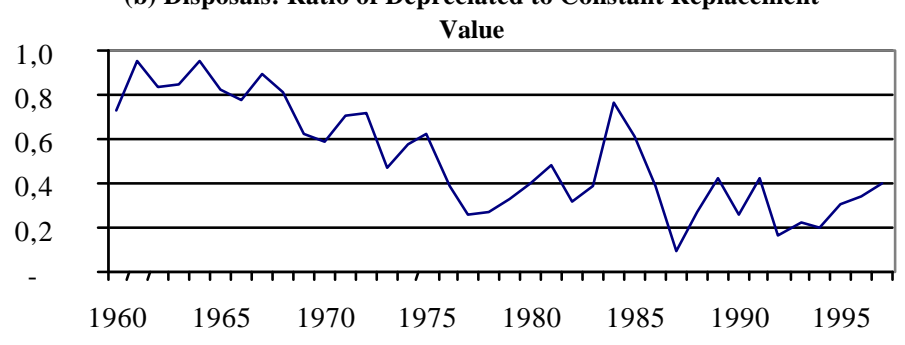

(c) GFCF: Ratio of Depreciated toConstant Replacement Value

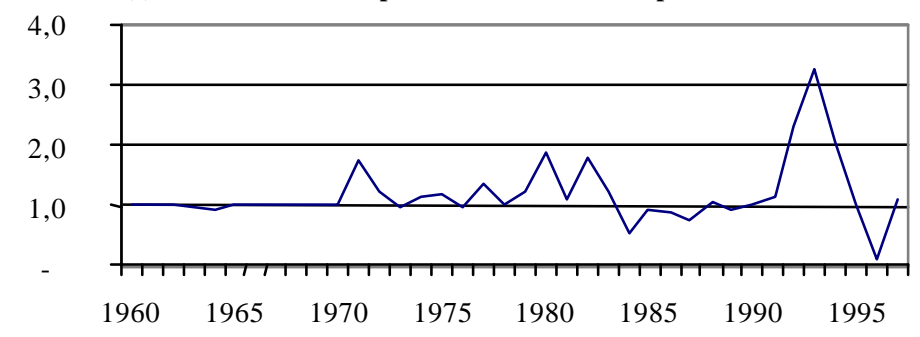

Source: Airclaims' CASE database and Airliner Price Guide as described in Annex B.. Depreciated values were estimated assuming linear depreciation over the 20 years asset life.

This is only partially confirmed by Figure 5-c, as the ratio of depreciated GFCF to non depreciated GFCF is not always above one. This is explained by composition effects: the above reasoning holds when there is only one acquisition and one disposal and when the acquisition is younger than the disposal. However, when acquisitions and disposals consists of a large variety of assets in terms of number, age and value, the difference between depreciated GFCF and non-depreciated GFCF may be positive or negative. Figure 
5-c thus confirms that non-depreciated GFCF may substantially differ from depreciated GFCF and the resulting gross capital will be also quite different.

The standard definition of GFCF, referred to here as market-price GFCF, is also inappropriate to measure net capital stocks. This is because market-price GFCF measures acquisitions and disposals at market prices, whereas assets of the same build-year within the stock have a hypothetical value, i.e. the constant replacement value less depreciation. A mixture is thus used of both market and hypothetical prices. Within the PIM framework, it would be more appropriate to use depreciated values for assets within the stock as well as those acquired and sold. This is the concept of depreciated GFCF. The difference between market GFCF and depreciated GFCF is illustrated in Figure 6.

\section{Figure 6: Depreciated Gross Fixed Capital Formation and Standard Gross Fixed Capital Formation, Aircraft, million 1980 Francs}

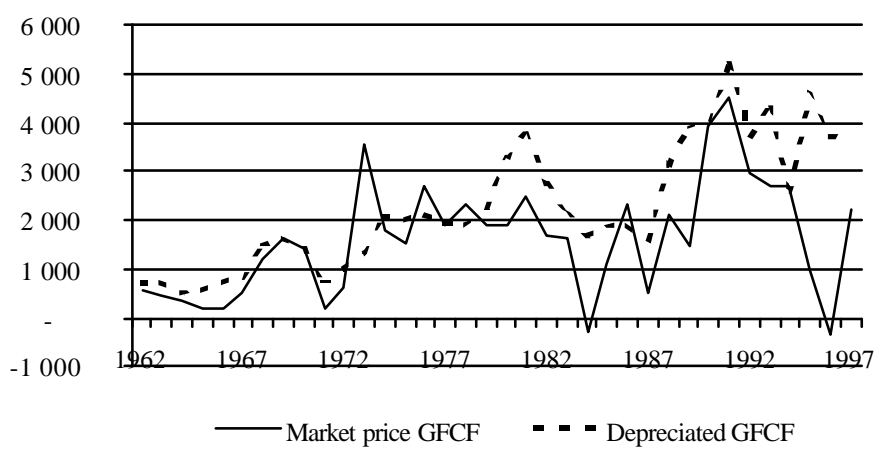

Sources: Standard gross fixed capital formation from Annex C. Depreciated gross fixed capital formation from Airclaims' CASE database and Airliner Price Guide as described in Annex B.

\subsubsection{Leased and Rented Assets}

Leased and rented aircraft have become a major part of capital formation in air transport. Their share in acquisitions and disposals has strongly risen over time (see Figure 7). By the late 1990s, ninety percent of the aircraft entering the capital stock was leased or rented. Leased and rented aircraft also strongly increased their share in the stock (see Figure 8). In quantity terms, its share rose from 3 per cent in 1965 to more than 60 per cent in 1998. The share of leased assets in the net stock has risen by almost as much. Nowadays, leased and rented aircraft thus account for a larger share than owned aircraft in air transport. Moreover, they are an important determinant of overall capital formation in air transport, as aircraft accounts for almost eighty percent of total capital formation in this sector. 
Figure 7: Share of Leased and Rented Aircraft in the Value of Acquisitions and Disposals (1980 French francs)

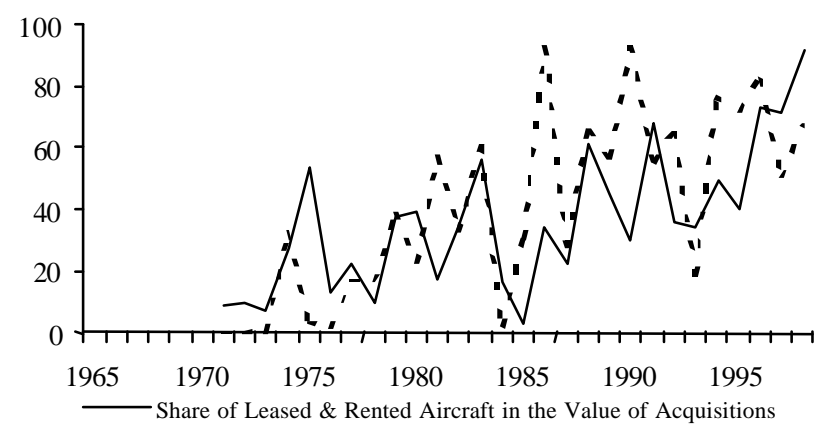

- - Share of Leased and Rented Aircraft in the Value of Disposals

Sources: Airclaims' CASE database and Airliner Price Guide as described in Annex B.

Figure 8: Share of Leased and Rented Aircraft in Capital Stock

(Number and Value of Net Stock in 1980 French francs)

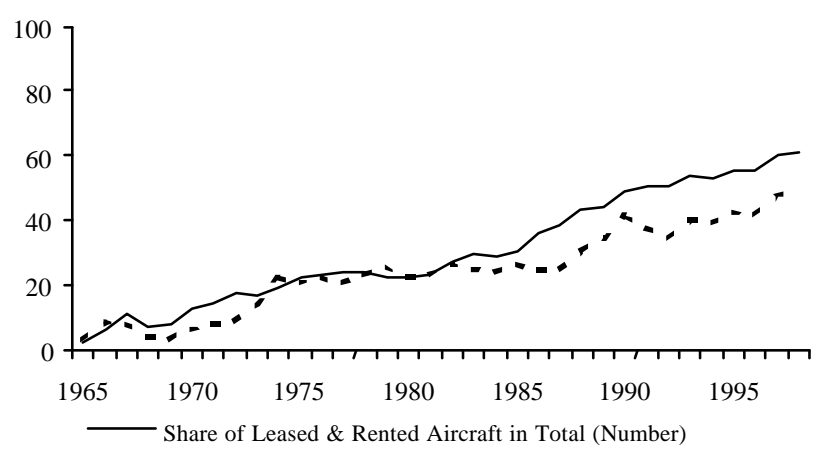

- - Share of Leased \& Rented Aircraft in Total (Net Stock Value)

Sources: See Figure 7.

The volume and value of leased assets is often underestimated. For example, the national accounts in France included only domestically leased assets which were reallocated to the user-industry. The only foreign leases included are those of the two largest air transport companies (Air France and Air Inter). The national accounts ignored all other aircraft leased by French operators from foreign leasing companies. Their share in the total stock of French aircraft increased substantially to a quarter in terms of numbers and to 15 per cent in terms of the value (see Figure 9). 
Figure 9: Share of Foreign Leased and Rented Aircraft (except Air France \& Air Inter) in Capital Stock (Number and Value of Net Stock in 1980 French francs)

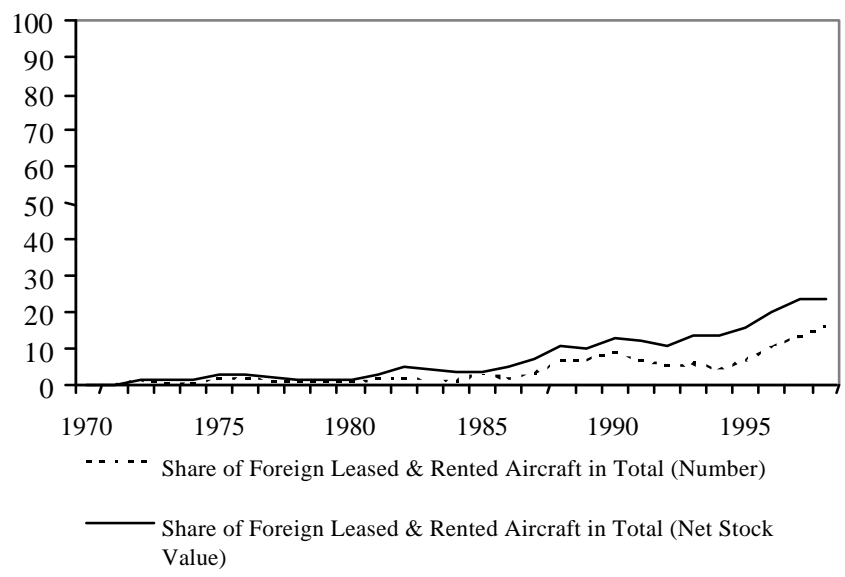

Sources: See Figure 7.

\subsection{Comparison of Capital Stocks Based on the PIM and on Registers}

Capital stock estimates obtained with register data are confronted with estimates of the perpetual inventory method. Capital formation at current prices in aircraft are taken from INSEE and the Ministry of Transport and cover the period 1962-97. The conversion to constant prices was done with the same deflator as used for the register data. We assumed an asset life of twenty years (Fraumeni, 1997). Retirements were supposed to be spread around the expected life year. The net stock was estimated assuming a geometric depreciation rate of 13.5 per cent per year (Fraumeni, 1997).

The PIM gross capital stock estimates were above those estimated using administrative registers, whereas the net stock estimates were mostly lower (see Figure 10). The maximum difference between the two was about twenty per cent. Two reasons explain the larger gross stock estimated by the PIM compared to the register value. Firstly, the GFCF in the PIM is overestimated, and thus also produce overestimated stocks, for the reasons outlined above. Secondly, the GFCF data used for the PIM include major revisions which are excluded from the register values of the stock. The lower PIM estimates for the net stock may originate from the assumed geometric depreciation compared to the linear depreciated used for the stocks estimated by the registers. 
Figure 10: Ratios of Capital Stocks Estimated by Perpetual Inventory Method to Administrative Record Stocks: Gross Stock and Net Stock

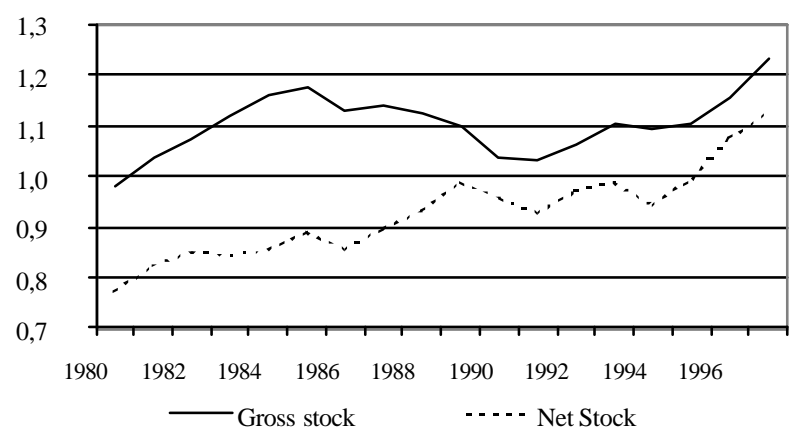

Sources: Stock estimates using the PIM: see Annex B. Stock estimates obtained by administrative records: Airclaims' CASE database and Airliner Price Guide (see also Annex B).

\subsection{Conclusion}

The perpetual inventory method is unsuitable for estimating capital stocks in industries with large turnovers of assets and/or large shares of rented and leased assets. When most assets are sold before they reached the end of their asset life, gross fixed capital formation based on market prices of acquisitions and disposals is unsuitable for the estimation of gross stocks. It underestimates the value of disposals relative to acquisitions and therefore overestimates GFCF. "The market-price" GFCF is also unsuitable for the estimation of net stocks, as it mixes hypothetical depreciated values for assets within the stock and market prices for assets entering or leaving the capital stock. The PIM is also unsuitable when a large part of the capital stock used in production is leased or rented, as GFCF in most countries ignores or only partly includes leased and above all rented assets.

For these industries, administrative registers of capital assets may provide a good alternative to the PIM. These registers permit coherent estimates of capital formation, gross and net stocks.

\section{International Productivity COMParisons}

\subsection{Introduction}

The series of capital services as presented in Section 2 are used here to measure capital, labour and total factor productivity (TFP). Capital and labour productivity measure the relative efficiency at which those inputs are used, while total factor productivity indicates how well labour and capital are jointly used. TFP is also interpreted as the contribution of technology to production, although it also captures other determinants of 
production not accounted for by capital and labour productivity such as international trade and structural change.

TFP is measured using traditional growth accounting. Suppose country $J$ has the following production function:

$$
Q_{J t}=f_{J t}\left(L_{J t}, K_{J t}\right)
$$

where $Q$ is real value added, $L$ is labour input (measured by hours worked) and $K$ is capital input (measured by capital services, see Section 2). Under the neo-classical assumptions, e.g. perfect competition and payments of factor inputs equal their marginal productivity, total factor productivity growth can be estimated using the Tövrnqvist discrete approximation to the Divisia index:

$$
\begin{aligned}
& \ln \left(T F P_{t}^{J} / T F P_{t-s}^{J}\right)=\ln \left(Q_{t}^{J} / Q_{t-s}^{J}\right)-\alpha^{J}(t, t-s) \ln \left(L_{t}^{J} / L_{t-s}^{J}\right) \\
& -\left(1-\alpha^{J}(t, t-s)\right) \ln \left(K_{t}^{J} / K_{t-s}^{J}\right)
\end{aligned}
$$

where $\alpha^{J}(t, t-s)$ is the average of the shares of labour compensation in value added in period $t-s$ to $t$. The growth accounting methodology is embedded into the neo-classical theory of production.

This Section will present the growth and productivity performance of France by subsector of transport in the period 1970-96. Subsequently, the French performance is compared to that of the Germany, the United Kingdom and the United States.

\subsection{Productivity Performance: A Comparison Between the French Sectors}

The growth rates of output, factor inputs and productivity are summarised in Table 6 (see also Figures 11 and 12). Three periods are distinguished: 1973-79 - the period between the two oil crises -, the 1980s and the 1990s. After a period of high output and productivity growth in transport in the 1970s, the 1980s and 1990s were characterised by a slowdown. This pattern was not unique for transport, but also found in other parts of the French economy (see O’Mahony, 1999). The overall transport performance hides large variations across sub-sectors: whereas output and productivity in air transport grew at high rates during all three sub-periods, that of other transport sectors sharply declined after the 1970s.

Labour input in terms of hours worked declined in the 1970s and 1980s due to a reduction in annual working hours and a decline in the number of persons engaged in railways, water transport and, surprisingly, air transport in the 1990s. This overall negative trend was reversed in the 1990s, mainly due to an employment increase in trucking which accounts for the largest share of employment in transport. 
Figure 11: Indices of Factor Inputs and Productivity, French Transport, 1970 = 100
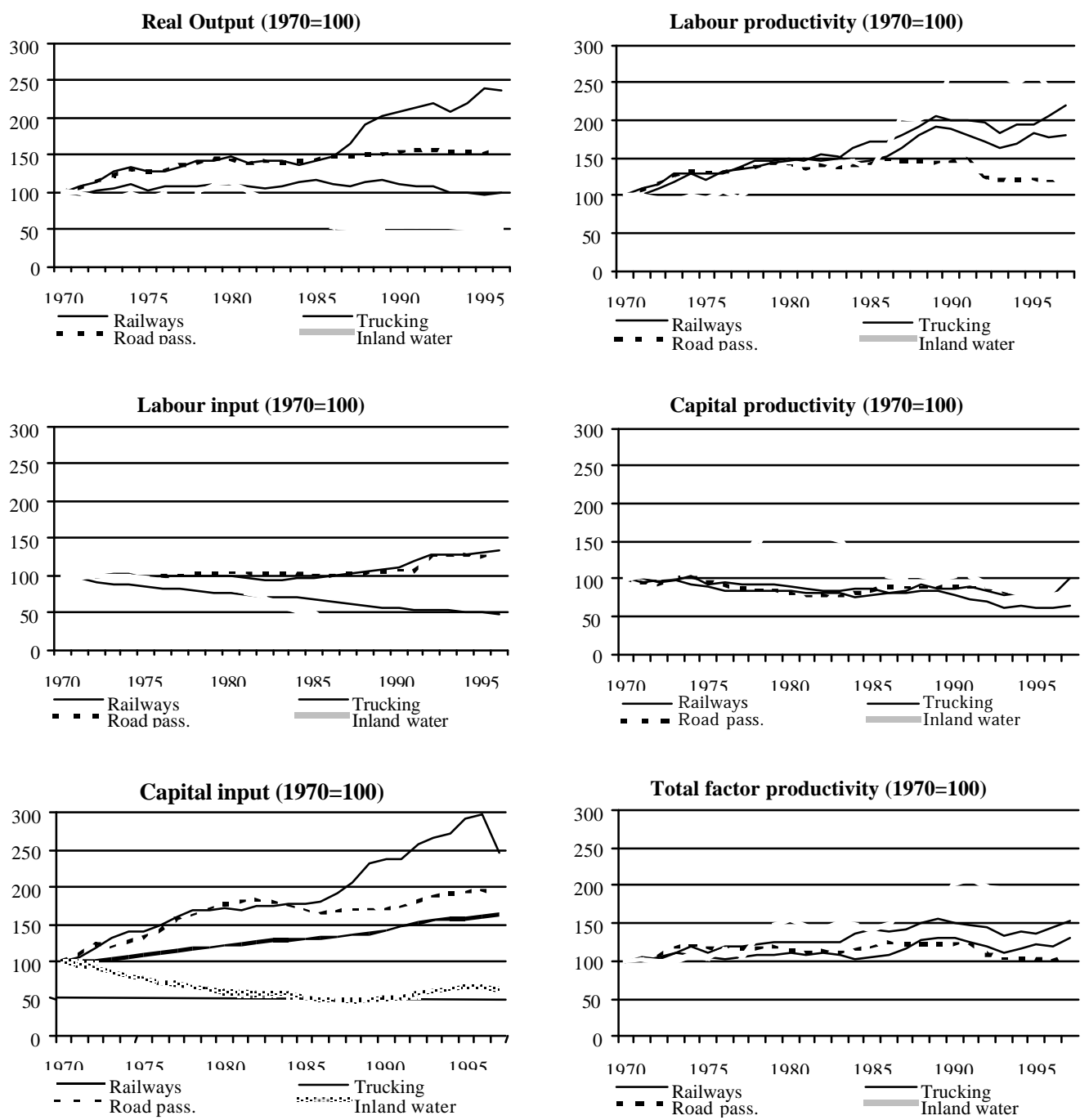

Sources: See Annexes D and E.

The growth of capital services also slowed down in all parts of transport after the 1970 s with the exception of air transport. The largest fall in capital services in maritime transport was partly due to the large substitution of owned ships for ships managed under a "flag of convenience" construction. This means that the owner transfers the register of the 
ship from France to mostly developing countries such as Liberia, Malta and Panama. ${ }^{16}$ The downsizing of the maritime transport is also due to the falling share in the world market for maritime goods transport.

\section{Figure 12: Indices of Factor Inputs and Productivity, French transport, $1970=100$}
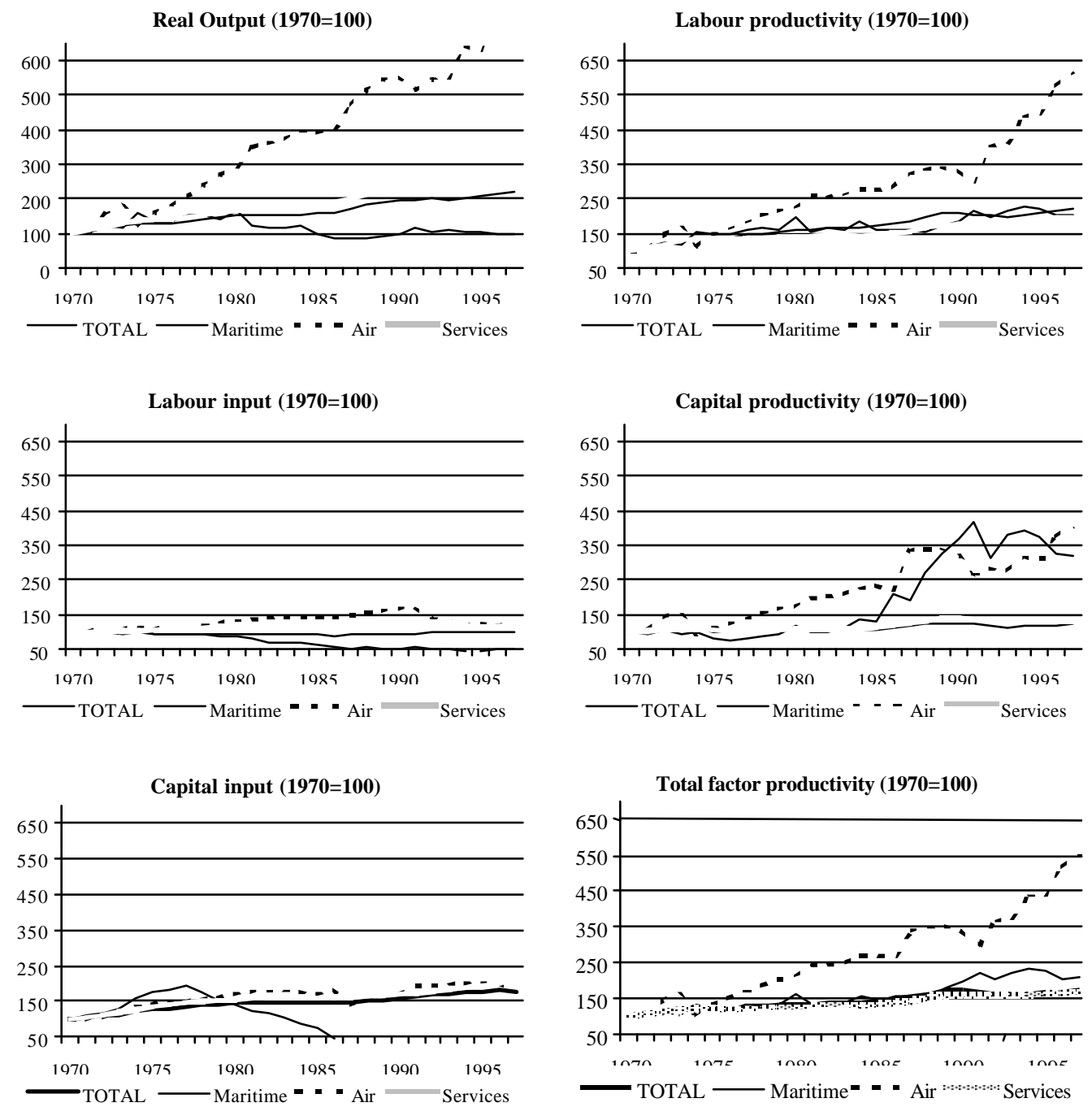

Sources: See Annexes D and E.

\footnotetext{
${ }^{16}$ The more flexible and less burdensome administrative and tax legislation of these countries allow for important reductions of operating cost. Ships registered in other countries are no longer part of a firm's owned capital stock.
} 
The labour productivity performance of the total transport sector was similar in the 1970s and 1980s, but dropped sharply in the 1990s. Air transport had the highest productivity growth throughout the 1970s to the 1990s. Maritime transport and railways were also among the better performing sectors. In railways, labour productivity growth disappeared in the 1990s. Maritime transport and railways partly achieved their high productivity growth due to sharp cuts in their labour force which largely unaffected output growth. Air transport was one of the few sectors that managed to create both employment and labour productivity growth simultaneously.

Airlines were not only the best performers in terms of labour productivity growth, but also in terms of capital productivity growth which exceeded 7 per cent in the 1980s. Capital productivity grew also at high rates in maritime transport in the 1980s. However, this outcome resulted from a large reduction of the owned shipping fleet which had a proportionally small impact on output.

The growth of total factor productivity in total transport increased in the $1980 \mathrm{~s}$ compared to the 1970s, but became negative in the 1990s. Again airlines outperformed other sectors. Maritime transport had also relatively high TFP growth rates. Railways, trucking and urban and interurban passenger transport performed similarly to overall transport.

Airlines, the most rapidly expanding transport sector in terms of capital and labour inputs, jointly with inland water and maritime transport were thus the branches with the best productivity performance. Productivity growth in railways and road passenger and road goods transport was poor and turned negative in the 1990s. The performance of trucking and transport services was in between.

\subsection{International Comparisons of Productivity in Transport}

To evaluate its productivity performance, France is compared to three countries with similar levels of economic development: (former Western) Germany, the United Kingdom and the United States. Germany and the UK are of a similar geographical size and population as France, whereas the United States is several times larger. Compared to the European countries, the United States can realise more scale economies due to its larger size. In particular in railways, the much larger network provides the US with a real advantage. It can load a train in New York which runs all the way to San Francisco. As the railways of each European country operates almost entirely on its own territory , trains need to be loaded and unloaded several times to generate the same quantity of ton kilometres as in the USA. The much smaller proportion of loading and unloading relative to the pure movement of goods in the USA compared to European countries is also true for road haulage which is the most important branch in transport. For other branches such as air and maritime transport, European countries benefit as much from scale economies as the USA as these activities are essentially international. 
Table 6: Total Transport: Growth of Output, Factor Inputs and Productivity (annual average growth rates)

\begin{tabular}{|c|c|c|c|c|c|c|c|c|}
\hline & $\begin{array}{c}\text { Railway } \\
\text { S }\end{array}$ & $\begin{array}{c}\text { Road } \\
\text { freight }\end{array}$ & $\begin{array}{c}\text { Road } \\
\text { Passenge } \\
\mathbf{r}\end{array}$ & $\begin{array}{l}\text { Inland } \\
\text { water }\end{array}$ & $\begin{array}{l}\text { Maritime } \\
\text { transport t }\end{array}$ & $\begin{array}{l}\text { Air } \\
\text { ransport }\end{array}$ & $\begin{array}{c}\text { Transport } \\
\text { Services }\end{array}$ & Total \\
\hline \multicolumn{9}{|c|}{ Value Added } \\
\hline $1973-79$ & 1.0 & 1.6 & 3.0 & 3.3 & 3.3 & 6.8 & 3.8 & 2.9 \\
\hline $1979-89$ & 0.5 & 3.7 & 0.3 & -7.8 & -4.6 & 7.4 & 3.5 & 2.7 \\
\hline $1989-96$ & -2.2 & 2.2 & 0.5 & 0.5 & 1.3 & 4.4 & 1.7 & 1.6 \\
\hline \multicolumn{9}{|c|}{ Hours worked } \\
\hline $1973-79$ & -2.2 & -0.5 & 0.7 & -2.4 & -2.4 & 2.5 & 2.1 & -0.3 \\
\hline $1979-89$ & -3.0 & 0.9 & 0.3 & -12.2 & -5.1 & 2.5 & 1.4 & -0.3 \\
\hline $1989-96$ & -2.2 & 3.3 & 3.3 & -1.5 & -1.1 & -3.1 & 0.0 & 1.2 \\
\hline \multicolumn{9}{|c|}{ Capital services } \\
\hline $1973-79$ & 2.3 & 4.1 & 6.2 & -5.2 & 3.0 & 4.8 & 4.3 & 3.8 \\
\hline 1979-89 & 1.5 & 3.3 & -0.1 & -2.4 & -15.8 & -0.1 & 0.8 & 0.7 \\
\hline $1989-96$ & 2.1 & 3.7 & 2.1 & 4.3 & 1.3 & 3.0 & 2.6 & 2.4 \\
\hline \multicolumn{9}{|c|}{ Labour productivity } \\
\hline $1973-79$ & 3.3 & 2.1 & 2.2 & 5.8 & 5.9 & 4.3 & 1.7 & 3.3 \\
\hline $1979-89$ & 3.7 & 2.8 & 0.1 & 5.0 & 0.5 & 4.7 & 2.1 & 3.0 \\
\hline $1989-96$ & 0.0 & -1.1 & -2.7 & 1.9 & 2.4 & 7.8 & 1.6 & 0.4 \\
\hline \multicolumn{9}{|c|}{ Capital productivity } \\
\hline $1973-79$ & -1.2 & -2.4 & -3.1 & 8.9 & 0.3 & 2.0 & -0.5 & -0.8 \\
\hline $1979-89$ & -1.0 & 0.4 & 0.4 & -5.5 & 13.3 & 7.4 & 2.7 & 2.0 \\
\hline $1989-96$ & -4.2 & -1.5 & -1.6 & -3.7 & 0.0 & 1.4 & -0.9 & -0.7 \\
\hline \multicolumn{9}{|c|}{ Total Factor Productivity } \\
\hline $1973-79$ & 2.0 & -0.3 & 0.3 & 6.9 & 4.0 & 3.6 & 0.9 & 1.8 \\
\hline $1979-89$ & 2.3 & 1.8 & 0.2 & 1.9 & 2.8 & 5.7 & 2.3 & 2.7 \\
\hline $1989-96$ & -1.1 & -1.3 & -2.5 & 0.0 & 1.9 & 5.6 & 0.6 & -0.1 \\
\hline
\end{tabular}

Sources: See Annexes D and E.

Data for the three other countries were taken from O'Mahony (1999). She presents a four sector breakdown: railways, water (e.g. maritime and inland water) transport, air transport and "other transport" (e.g. trucking and urban and interurban transport, and services related to transport). Due to data problems, no series were available for water transport in the UK and air transport in Germany as well for "other transport" in both countries. O'Mahony's series start in 1950 compared to 1970 in this study. She provides a breakdown into two types of capital assets: non-residential structures on the one hand and machinery and equipment on the other. 


\subsubsection{Total Transport}

France had the highest growth rates of output in the 1970s and 1980s but the lowest ones in the 1990s. Germany was the output growth leader in the 1990s. During most of the period 1970-95, the volume of labour services shrank in all three European countries in contrast to the United States where employment grew at modest rates throughout. The largest employment cuts were in France. On the other hand, capital services grew faster in France than elsewhere (see Table 7 and Figure 13).

The France productivity performance was mixed compared to the other countries: it performed better in terms of labour productivity growth but worse in terms of capital and total factor productivity gains. Labour productivity growth in France was amongst the highest in the 1970s and 1980s, after which it declined relative to the other countries. The UK showed the highest capital productivity growth in the 1970s and 1980s. France performed poorly with respect to capital productivity and showed a mediocre total factor productivity performance.

Table 7: Total Transport: Growth of Output, Factor Inputs and Productivity (annual average growth rates)

\begin{tabular}{|c|c|c|c|c|c|c|c|c|}
\hline & \multicolumn{4}{|c|}{ Value added } & \multicolumn{4}{|c|}{ Labour productivity } \\
\hline & France & $\begin{array}{c}\text { German } \\
\mathbf{y} \\
\end{array}$ & UK & USA & France & $\begin{array}{c}\text { German } \\
\mathbf{y} \\
\end{array}$ & UK & USA \\
\hline $1973-79$ & 2.9 & 2.9 & 0.4 & 2.5 & 3.3 & 4.2 & 1.0 & 1.3 \\
\hline $1979-89$ & 2.7 & 2.0 & 2.6 & 1.8 & 3.0 & 2.4 & 4.1 & 0.6 \\
\hline \multirow[t]{3}{*}{$1989-95$} & 1.4 & 4.0 & 2.6 & 3.7 & 0.2 & 3.5 & 3.6 & 1.3 \\
\hline & \multicolumn{4}{|c|}{ Hours worked } & \multicolumn{4}{|c|}{ Capital productivity } \\
\hline & France & $\begin{array}{c}\text { German } \\
\mathbf{y} \\
\end{array}$ & UK & USA & France & $\begin{array}{c}\text { German } \\
\mathbf{y} \\
\end{array}$ & UK & USA \\
\hline $1973-79$ & -0.3 & -1.2 & -0.6 & 1.2 & -0.8 & 1.3 & -1.1 & 0.7 \\
\hline $1979-89$ & -0.3 & -0.4 & -1.4 & 1.3 & 2.0 & 1.5 & 3.5 & 2.7 \\
\hline \multirow[t]{3}{*}{ 1989-95 } & 1.2 & 0.5 & -1.0 & 2.4 & -1.1 & 3.3 & -0.1 & 4.6 \\
\hline & \multicolumn{4}{|c|}{ Capital services } & \multicolumn{4}{|c|}{ Total factor productivity } \\
\hline & France & $\begin{array}{c}\text { German } \\
\mathbf{y} \\
\end{array}$ & UK & USA & France & $\begin{array}{c}\text { German } \\
\mathbf{y} \\
\end{array}$ & UK & USA \\
\hline $1973-79$ & 3.8 & 1.6 & 1.4 & 1.8 & 1.8 & 3.3 & -0.1 & 1.1 \\
\hline $1979-89$ & 0.7 & 0.5 & -0.9 & -0.8 & 2.7 & 2.1 & 3.6 & 1.2 \\
\hline $1989-95$ & 2.5 & 0.7 & 2.6 & -0.9 & -0.4 & 3.4 & 1.7 & 2.2 \\
\hline
\end{tabular}

Sources: See Annexes D, E and F. 
Figure 13: Indices of Factor Inputs and Productivity, Total transport, $1970=100$
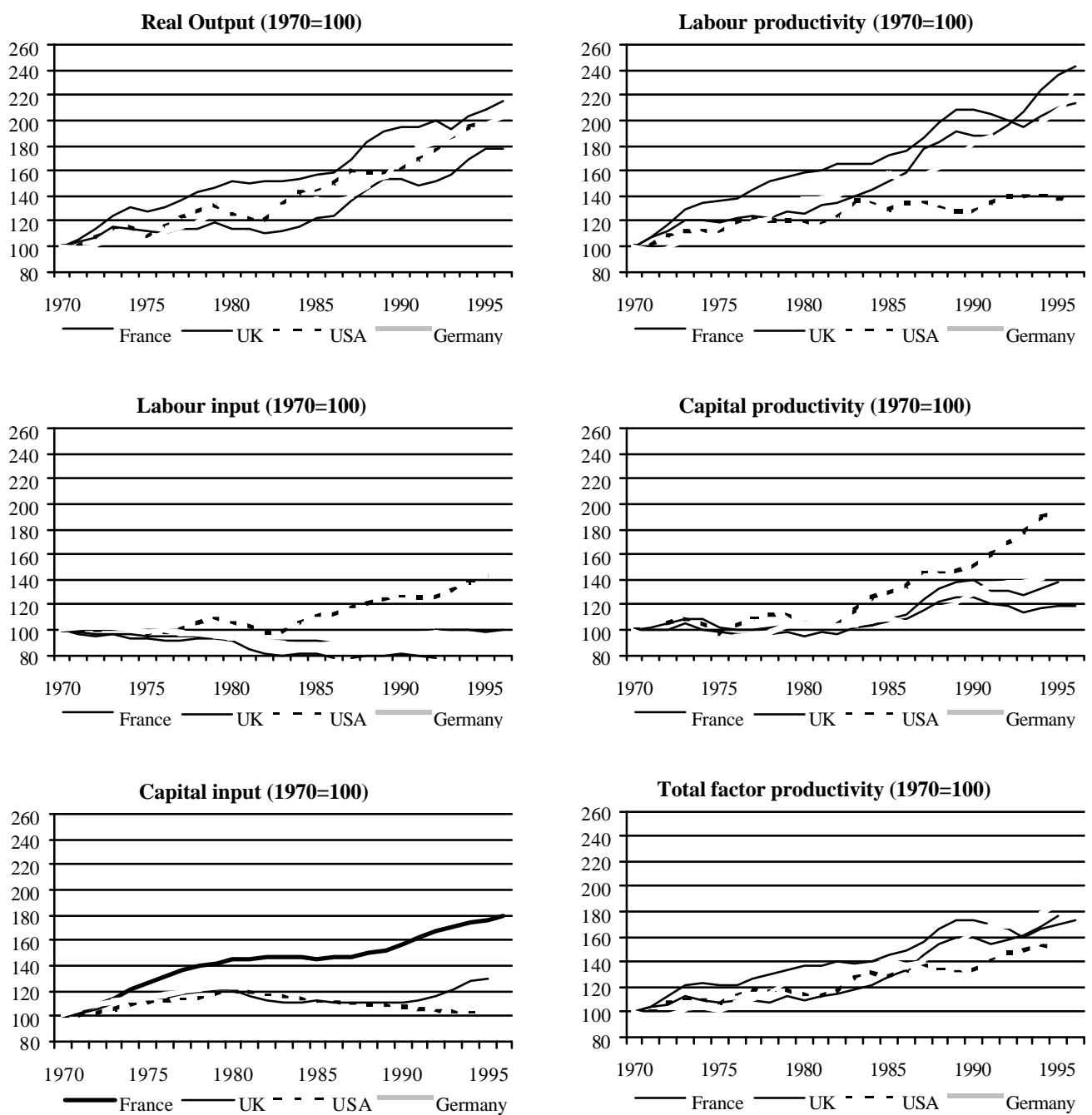

Sources: See Annexes D, E and F.

\subsubsection{Railways}

Railways are very different in Europe and the United States. In Europe, most revenue is generated by passenger transport, whereas in the United States, freight transport accounts for almost all output. In the United States, geographical distances are the most important reason for the low share of passenger travel as most people travel by air. Its large surface also allows for economies of scale as the average distance over which freight is carried is much longer than in the European countries. As such, the Europeans need 
relatively much more loading and unloading services to generate the same number of ton kilometres as the USA.

In all countries, the volume of labour services has been cut. This is mainly due to the closure of many regional rail tracks in all countries, and the large decline in passenger travel by trains in the United States. In the European countries, employment in rail freight transport has been cut as trucks have taken over a large part of freight transport. Finally, modern rolling stock requires less maintenance which reduced the number of mechanics.

Capital services grew most in France (see Table 8 and Figure 14). This is mostly explained by the massive construction of fast speed train (TGV) networks which is unprecedented in the other three countries. Nowadays most of the inter-city travel is by TGVs running at $300 \mathrm{~km}$ per hour. The modernisation of the rail network in the other countries was much slower.

Table 8: Railways: Growth of Output, Factor Inputs and Productivity (annual average growth rates)

\begin{tabular}{|c|c|c|c|c|c|c|c|c|}
\hline & \multicolumn{4}{|c|}{ Value added } & \multicolumn{4}{|c|}{ Labour productivity } \\
\hline & France & $\begin{array}{c}\text { German } \\
\mathbf{y} \\
\end{array}$ & UK & USA & France & $\begin{array}{c}\text { German } \\
\mathbf{y} \\
\end{array}$ & UK & USA \\
\hline $1973-79$ & 1.0 & -1.8 & -1.2 & 1.8 & 3.3 & 2.6 & 1.0 & 3.7 \\
\hline $1979-89$ & 0.5 & -0.9 & -0.2 & 1.3 & 3.7 & 2.8 & 3.6 & 7.8 \\
\hline \multirow[t]{3}{*}{ 1989-95 } & -3.1 & -1.6 & -2.7 & 7.5 & -0.9 & 2.7 & 0.2 & 10.2 \\
\hline & \multicolumn{4}{|c|}{ Hours worked } & \multicolumn{4}{|c|}{ Capital productivity } \\
\hline & France & $\begin{array}{c}\text { German } \\
\mathbf{y} \\
\end{array}$ & UK & USA & France & $\begin{array}{c}\text { German } \\
\mathbf{y} \\
\end{array}$ & UK & USA \\
\hline $1973-79$ & -2.2 & -4.2 & -2.2 & -1.8 & -1.2 & -2.3 & -0.3 & -2.0 \\
\hline 1979-89 & -3.0 & -3.6 & -3.6 & -6.0 & -1.0 & -0.9 & -0.1 & 3.1 \\
\hline \multirow[t]{3}{*}{$1989-95$} & -2.2 & -4.2 & -2.9 & -2.5 & -5.3 & -1.6 & -6.6 & 7.5 \\
\hline & \multicolumn{4}{|c|}{ Capital services } & \multicolumn{4}{|c|}{ Total factor productivity } \\
\hline & France & $\begin{array}{c}\text { German } \\
\mathbf{y} \\
\end{array}$ & UK & USA & France & $\begin{array}{c}\text { German } \\
\mathbf{y} \\
\end{array}$ & UK & USA \\
\hline $1973-79$ & 2.3 & 0.5 & -0.9 & 3.9 & 2.0 & 0.9 & 0.3 & 2.1 \\
\hline $1979-89$ & 1.5 & 0.0 & 0.0 & -1.7 & 2.3 & 1.6 & 1.5 & 6.1 \\
\hline 1989-95 & 2.4 & 0.0 & 4.2 & -0.1 & -2.1 & 1.4 & -3.4 & 8.9 \\
\hline
\end{tabular}

Sources: See Annexes D, E and F.

The USA outperformed the European countries in terms of labour, capital and total factor productivity mostly because of scale economies. Moreover, as freight transport requires relatively less labour and capital than passenger transport, the USA has an advantage over the European countries where the share of passenger transport in total 
output is a lot higher. Among the European countries, France performs rather well in terms of labour productivity but poorly in capital and total factor productivity.

Figure 14: Indices of Growth of Factor Inputs and Productivity, Railways, 1970=100
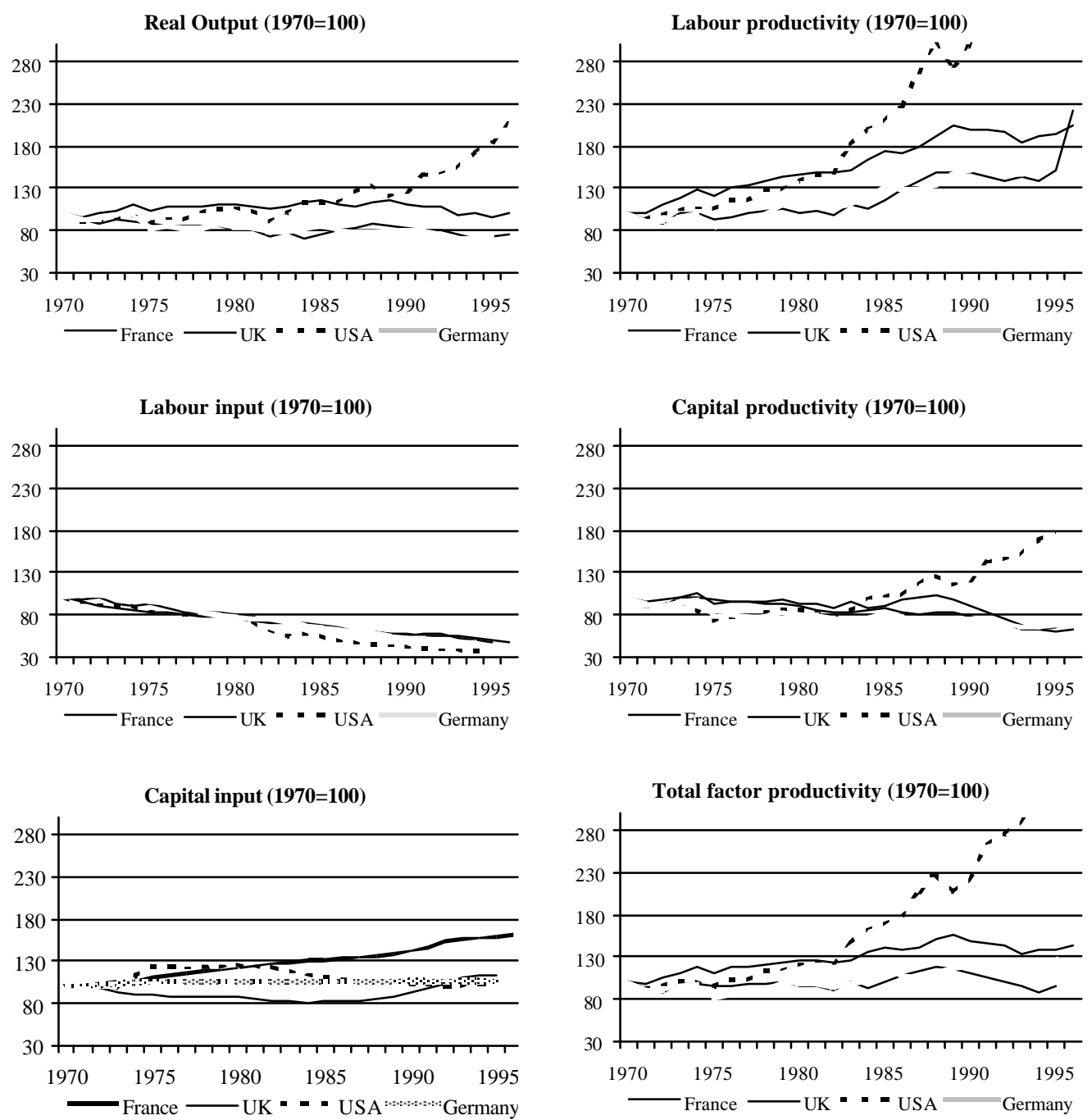

Sources: See Annexes D, E and F.

\subsubsection{Water Transport}


Water transport consists of inland water and maritime transport. In all three countries, inland water transport is by far smaller than maritime transport. Moreover, inland water transport is slowly disappearing in France and Germany as their goods transport is taken over mostly by truck transport. Maritime transport is also in decline in the three countries. Output growth was close to zero in all three countries. Employment in the two branches combined fell by more than 50 per cent in France and Germany, while the decrease in the United States was somewhat smaller in the period 1970-95. In France, the capital stock in water transport was also reduced by half. On the contrary, in Germany and the United States, the capital stock even slightly increased between 1970 and 1995 (see Table 9 and Figure 15).

Table 9: Water Transport: Growth of Output, Factor Inputs and Productivity (annual average growth rates)

\begin{tabular}{|c|c|c|c|c|c|c|}
\hline & \multicolumn{3}{|c|}{ Value Added } & \multicolumn{3}{|c|}{ Labour productivity } \\
\hline & France & Germany & USA & France & Germany & USA \\
\hline $1973-79$ & 3.5 & 3.7 & 2.0 & 6.0 & 9.0 & 2.1 \\
\hline $1979-89$ & -4.9 & -2.2 & -1.6 & 1.6 & 2.6 & 0.2 \\
\hline \multirow[t]{3}{*}{$1989-95$} & 2.4 & 1.8 & 0.7 & 4.5 & 4.6 & -0.3 \\
\hline & \multicolumn{3}{|c|}{ Hours worked } & \multicolumn{3}{|c|}{ Capial productivity } \\
\hline & France & Germany & USA & France & Germany & USA \\
\hline $1973-79$ & -2.4 & -4.9 & -0.1 & -1.1 & 2.1 & -2.4 \\
\hline 1979-89 & -6.5 & -4.6 & -1.8 & 8.0 & -0.5 & 0.8 \\
\hline \multirow[t]{3}{*}{$1989-95$} & -2.0 & -2.7 & 1.0 & 4.4 & 2.7 & 2.6 \\
\hline & \multicolumn{3}{|c|}{ Capital services } & \multicolumn{3}{|c|}{ Total factor productivity } \\
\hline & France & Germany & USA & France & Germany & USA \\
\hline $1973-79$ & 4.6 & 1.6 & 4.5 & 3.2 & 5.5 & 0.8 \\
\hline 1979-89 & -12.0 & -1.6 & -2.3 & 3.3 & 0.8 & 0.4 \\
\hline $1989-95$ & -1.9 & -0.9 & -1.9 & 4.7 & 3.7 & 0.5 \\
\hline
\end{tabular}

Sources: See Annexes D, E and F.

Germany was the country with the largest labour productivity increase, followed by France. Productivity increased very little in the USA. In terms of capital and total factor productivity, France outperformed Germany and the USA. The French performance was achieved through a large reduction of the shipping fleet while it managed to maintain output. 
Figure 15: Indices of Factor Inputs and Productivity, Waterways, 1970=100
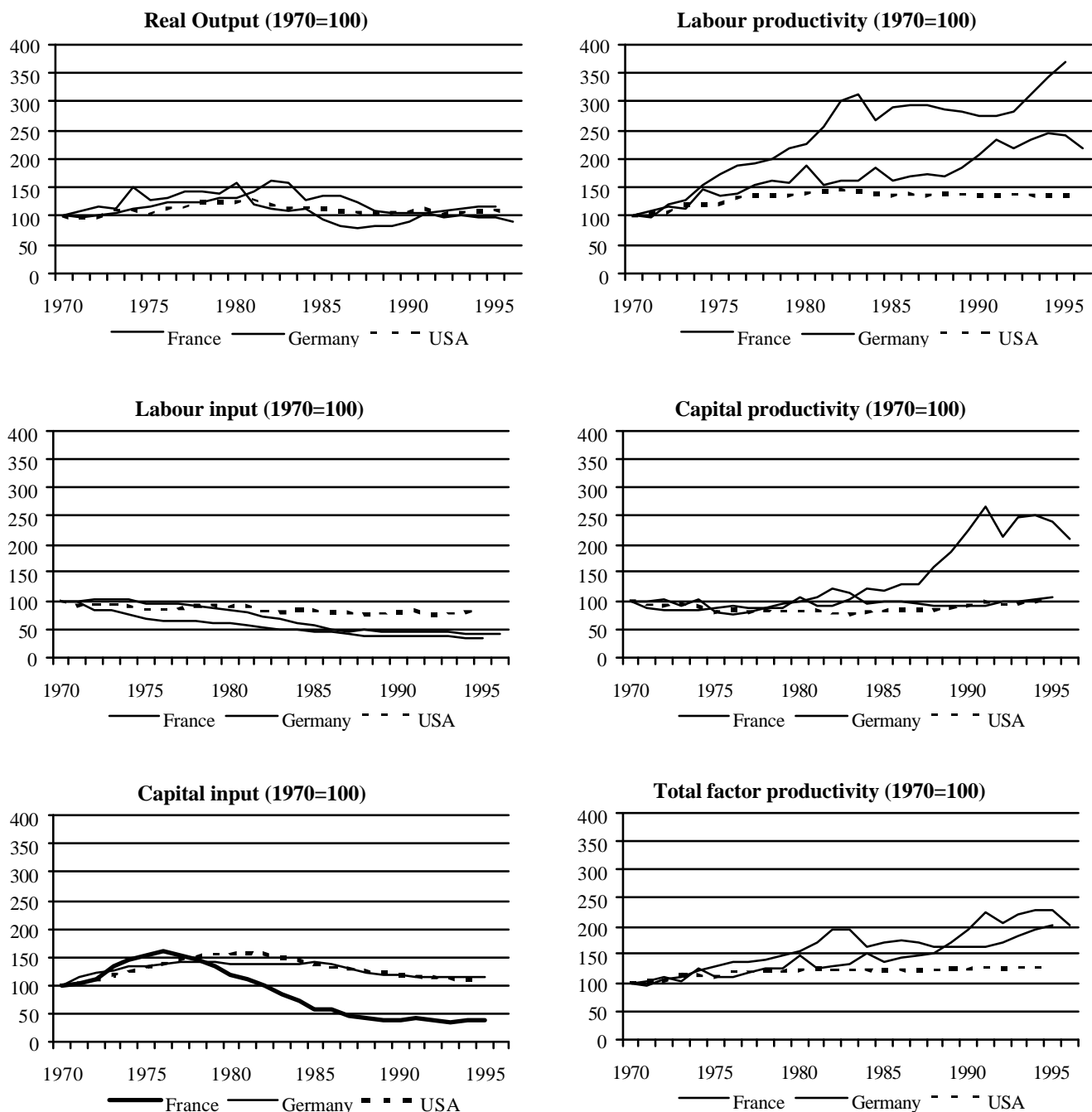

Sources: Annexes D, E and F.

\subsubsection{Airlines}

The main results for airlines are summarised in Table 10 and Figure 16. Between 1973 and 1979, labour input and capital input grew faster in France than in the UK and the USA. From 1979 onwards, labour input increased most in the United States. In the 1970s, the growth of employment in France was accompanied by substantial labour productivity growth. In the 1980s and 1990s, French airlines continued to improve their labour productivity at higher rates then those in the UK and the USA. However, in the 1990s, 
productivity growth went together with a large personnel cut by 20 percent. In the UK and the USA, employment continued to increase, albeit at lower rates than in the $1980 \mathrm{~s}$.

Table 10: Airlines: Growth of Output, Factor Inputs and Productivity, (annual average growth rates)

\begin{tabular}{|c|c|c|c|c|c|c|}
\hline & \multicolumn{3}{|c|}{ Value Added } & \multicolumn{3}{|c|}{ Labour productivity } \\
\hline & France & UK & USA & France & UK & USA \\
\hline $1973-79$ & 6.8 & 9.1 & 6.7 & 4.3 & 7.1 & 4.2 \\
\hline $1979-89$ & 7.4 & 4.0 & 4.8 & 4.7 & 1.8 & 0.6 \\
\hline \multirow[t]{3}{*}{$1989-95$} & 2.4 & 7.9 & 6.2 & 6.5 & 5.6 & 3.9 \\
\hline & \multicolumn{3}{|c|}{ Hours worked } & \multicolumn{3}{|c|}{ Capial productivity } \\
\hline & France & UK & USA & France & UK & USA \\
\hline $1973-79$ & 2.5 & 1.9 & 2.4 & 2.0 & 6.8 & 3.7 \\
\hline $1979-89$ & 2.5 & 2.2 & 4.3 & 7.4 & 7.8 & 2.9 \\
\hline \multirow[t]{3}{*}{ 1989-95 } & -3.9 & 2.1 & 2.3 & -1.7 & 2.1 & 5.8 \\
\hline & \multicolumn{3}{|c|}{ Capital services } & \multicolumn{3}{|c|}{ Total factor productivity } \\
\hline & France & UK & USA & France & UK & USA \\
\hline $1973-79$ & 4.8 & 2.2 & 2.9 & 3.6 & 6.4 & 3.8 \\
\hline $1979-89$ & -0.1 & -3.5 & 1.9 & 5.7 & 4.4 & 0.8 \\
\hline $1989-95$ & 4.2 & 5.7 & 0.4 & 3.8 & 3.5 & 4.3 \\
\hline
\end{tabular}

Sources: Annexes D, E and F.

In France, the growth of capital services in the 1970s was higher than that in other periods, as well as higher than in other countries. In the 1980s, capital services grew more slowly in all countries and became even negative in the UK; in the 1990s growth recovered except for the United States where it dropped to almost zero. Capital productivity grew fastest in France and the UK in the 1980s, compared to the 1990s in the United States. In France, capital productivity fell until 1995 when it started to grow again.

Total factor productivity grew always at rates above three percent, except for the USA in the 1980s. France experienced very high TFP growth in the 1980s, while the British airlines showed rapid progress in the prior decade. 
Figure 16: Indices of Factor Inputs and Productivity, Airlines, 1993=100
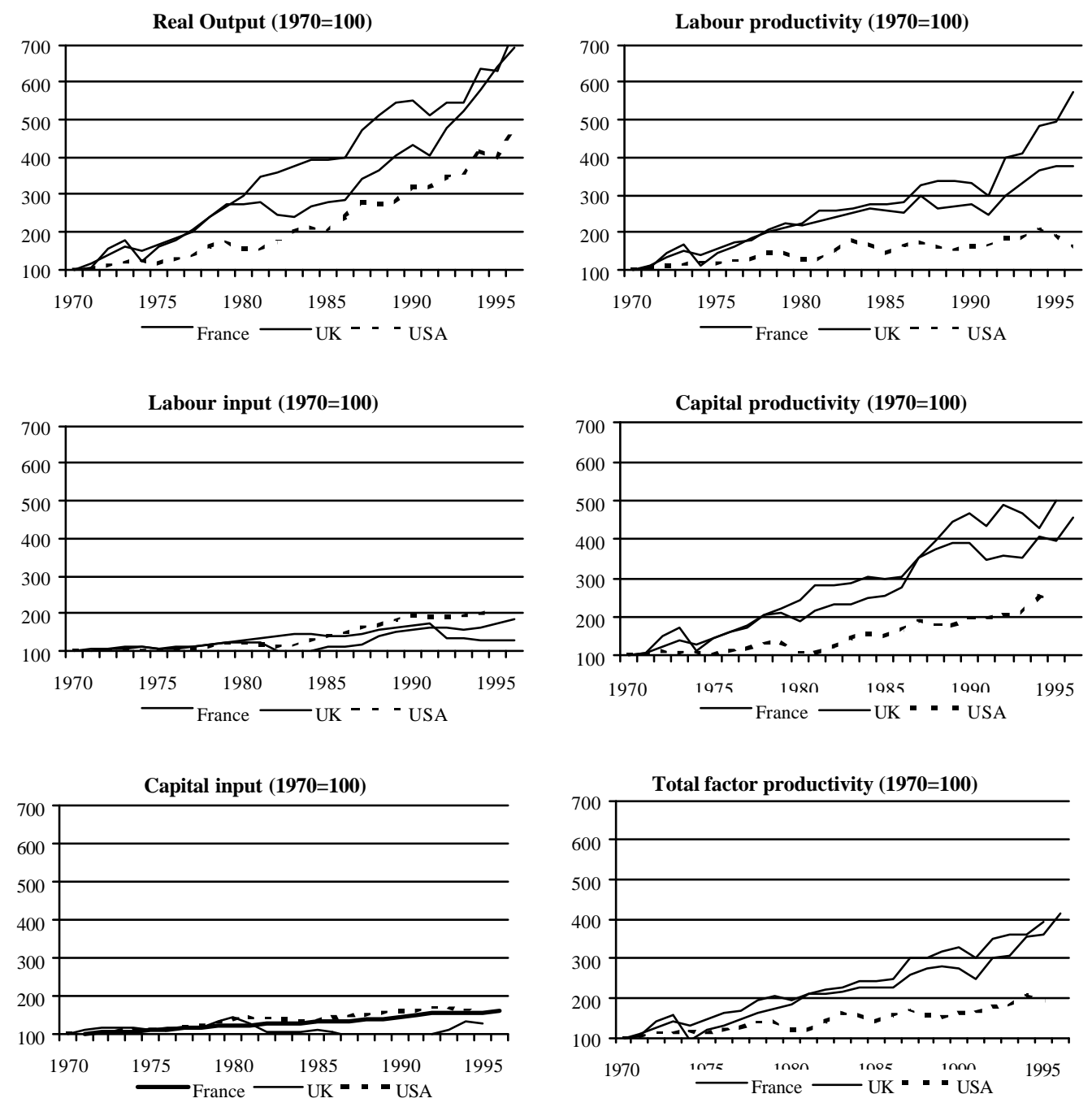

Sources: Annexes D, E and F. 


\subsubsection{Road Freight, Road Passenger and Services Related to Transport}

No series on labour and capital inputs are available for the other parts of transport in Germany and the United Kingdom. For the United States, O'Mahony (1999) merged the other transport sectors: trucking, urban and interurban passenger transport and transport services. Compared to the United States, employment in this part of transport grew at a far slower rate. The opposite was for the growth of output and volume of capital services. Labour productivity grew faster in France, and capital productivity increased less than in the USA. Total factor productivity gains were similar in both countries (see Table 11).

Table 11: Road Freight, Road Passenger, Transport Services: Growth of Output, Factor Inputs and Productivity (annual average growth rates)

\begin{tabular}{|c|c|c|c|c|}
\hline & \multicolumn{2}{|c|}{ Value added } & \multicolumn{2}{|c|}{ Labour productivity } \\
\hline & France & USA & France & USA \\
\hline $1973-79$ & 2.8 & 1.9 & 2.2 & 0.0 \\
\hline $1979-89$ & 2.9 & 1.3 & 2.0 & -0.7 \\
\hline \multirow[t]{3}{*}{$1989-95$} & 1.9 & 2.4 & -0.6 & -0.5 \\
\hline & \multicolumn{2}{|c|}{ Hours worked } & \multicolumn{2}{|c|}{ Capital productivity } \\
\hline & France & USA & France & USA \\
\hline 1973-79 & 0.6 & 1.8 & -1.7 & -0.7 \\
\hline 1979-89 & 0.8 & 2.0 & 1.6 & 1.8 \\
\hline \multirow[t]{3}{*}{ 1989-95 } & 2.6 & 2.9 & -0.7 & 5.1 \\
\hline & \multicolumn{2}{|c|}{ Capital services } & \multicolumn{2}{|c|}{ Total factor productivity } \\
\hline & France & USA & France & USA \\
\hline 1973-79 & 4.6 & 2.6 & 0.4 & -0.3 \\
\hline 1979-89 & 1.3 & -0.5 & 1.8 & 0.1 \\
\hline $1989-95$ & 2.6 & -2.6 & -0.7 & 1.0 \\
\hline
\end{tabular}

Sources: Annexes D, E and F. 
Figure 17: Indices of Factor Inputs and Productivity, Other transport, 1970=100
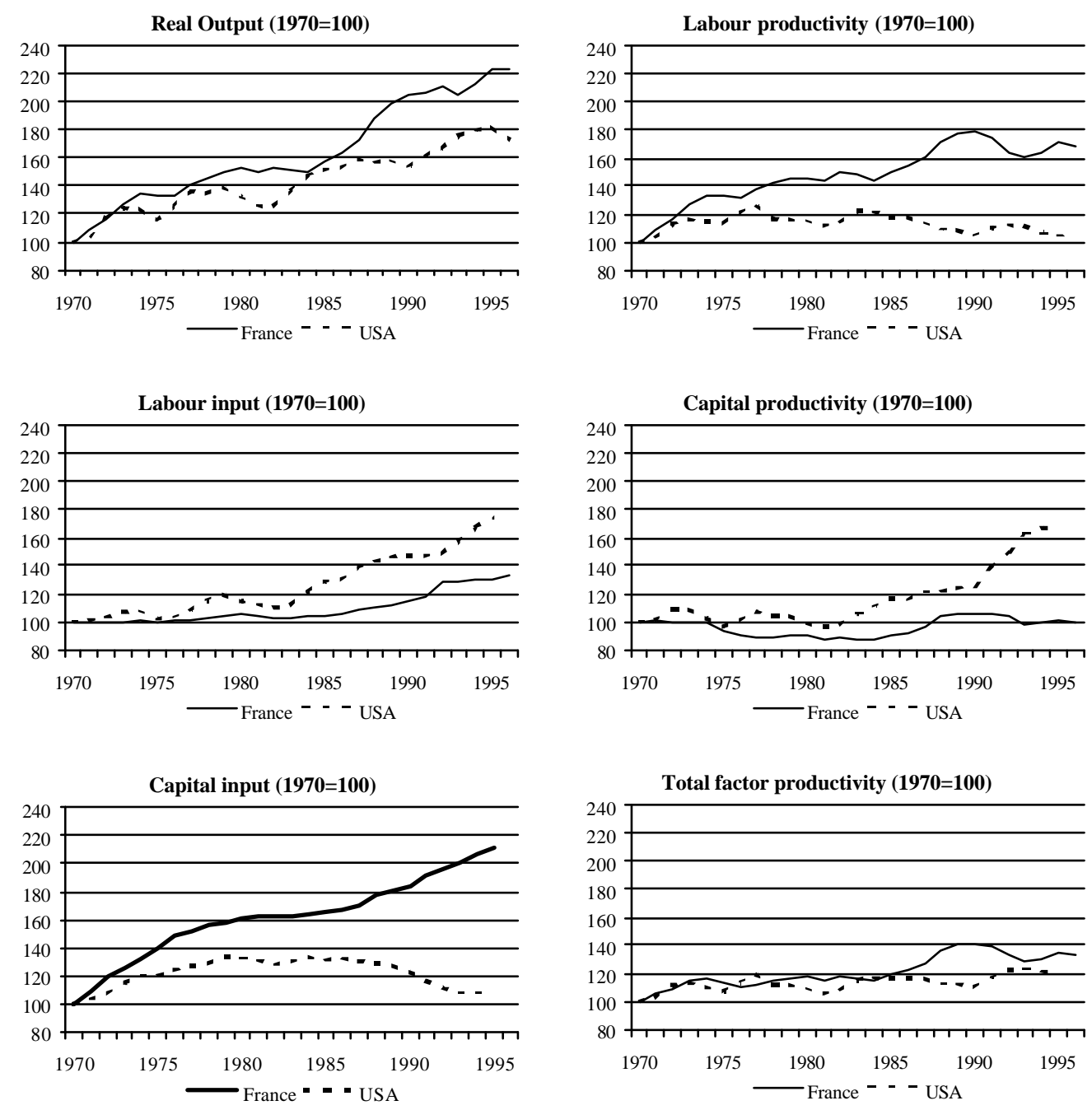

Sources: Annexes D, E and F.

\section{CONCLUSION}

The main novelty of this study is the construction of a series of capital stocks and services for eight sub-sectors in French transport, hitherto unavailable, and the comparison of the productivity performance both between transport sectors and between France and other countries from 1970 onwards. Within a productivity framework, all variables are flows and therefore capital input should be measured by capital services and not by stocks. Only the former is consistent with other measures such as GDP and hours worked. Capital services are the product of the volume of capital services, at the level of individual assets 
assumed proportional to the net capital stock, and the cost of capital utilisation. The user cost equals the sum of depreciation, real interest and capital gains. In the first part of this study the variety of methods available to measure net capital stocks is discussed, of which direct surveys are considered the most reliable. As such surveys are not carried out in France, a second-best method was used which is referred to as the Perpetual Inventory Method (PIM). The PIM consists of cumulating gross fixed capital formation (GFCF) over the assumed asset life of an asset. GFCF equals acquisitions minus disposals. Net stocks were estimated by assuming geometric depreciation, a pattern that coincides with the evolution of prices of second-hand assets in transport.

The PIM has been used to measure net capital stocks in all sectors except for the stock of transport equipment in air and maritime transport. This is because airlines rely heavily on leased and (long term) rented capital. Capital stock estimates obtained with the PIM only cover owned assets and exclude leases and rentals. The PIM thus underestimates the capital stock used in production. The PIM also produces biased capital stock estimates for firms selling large shares of their assets before they reach the end of their asset life, because disposals are often not measured or underestimated. High asset turnovers are common in air transport, but also in maritime transport. In both sectors, instead of the PIM, administrative records were used.

For each of the eight sub-sectors of transport, the net stocks of infrastructure, transport equipment and other types of machinery and equipment were estimated for the period 1970-97. In fact, railways account for one third and transport services (airports, ports, toll roads) for one half of all transport infrastructure. Half of the stocks of transport equipment and other types of machinery and equipment are part of railways. In the past three decades, the shares of air transport and trucking in transport equipment increased, whereas that of water transport decreased. Capital services, i.e. the sum of net stocks of non-residential structures, transport and other equipment weighted by their user cost, grew fastest in air transport and trucking, whereas in inland water and maritime transport the volume of capital services fell.

The capital services estimates were used to analyse the productivity performance since the 1970s. Total factor productivity is estimated using the Tövrnqvist discrete approximation to the Divisia index. Between 1970 and 1997, labour productivity grew fastest in air and maritime transport. In the 1970s and the 1990s, capital productivity fell in all branches except air and maritime transport. In the 1980s, all branches showed minor capital productivity gains. Air and maritime transport also showed the best TFP performance.

The French performance was compared with that of Germany, the UK and the United States. It was found that the variance of productivity patterns across transport sectors in France resembled that of the other countries. Overall productivity gains in Germany and the United Kingdom were similar to those in France and the three European countries outperformed the USA. In all countries air transport was the branch with the highest productivity growth rates. The USA was the only country with large productivity gains in railways. France outperformed other countries in terms of productivity growth in air and 
maritime transport. In the other branches, productivity growth in France was below that of the other countries.

The net capital stock and services estimates presented here may be refined in various ways. Firstly, in the absence of specific information on asset lives and depreciation patterns by sub-sector of transport, American assumptions were used. This bias could be corrected if more information would be collected on the practices of French firms. Secondly, the use of administrative records to estimate stocks, which is more reliable than the PIM, could be extended to other sectors, such as railways, trucking, and urban and interurban passenger transport, as well as other countries. Thirdly, the estimation of benchmark stocks could be improved by extrapolating further backwards the GFCF series or by reviewing information contained in company's balance sheets. Fourthly, the estimation of capital services can be refined by including sector-specific data on interest and tax rates. 

ANNEX A - French Industrial Classification: NAP AND NAF

\begin{tabular}{|c|c|c|c|}
\hline $\begin{array}{l}\text { International } \\
\text { Comparisons }\end{array}$ & $\begin{array}{l}\text { French National } \\
\text { Accounts }\end{array}$ & Nomenclature d'activité et de produit & Nomenclature des activités françaises \\
\hline Railways & Rail transport & 68 Transports ferroviares & 601 Transports ferroviaires \\
\hline \multirow[t]{4}{*}{ Other inland transport } & Road freight transport & $\begin{array}{l}6911 \text { Transports de marchandises zone longue } \\
6912 \text { Transports de marchandises zone courte } \\
6924 \text { Démenagements } \\
6925 \text { Location de vehicules industriels }\end{array}$ & $\begin{array}{l}602 \mathrm{M} \text { Transports routiers de marchandises interurbains } \\
602 \mathrm{~L} \text { Transports } 5 \text { outiers de marchandises de } \\
602 \mathrm{~N} \text { Démenágements } \\
602 \mathrm{P} \text { Locations de camions avec }\end{array}$ \\
\hline & Road passenger transport & $\begin{array}{l}6921 \text { Transports urbains de voyageurs } \\
6922 \text { Transports routiers de voyageurs }\end{array}$ & 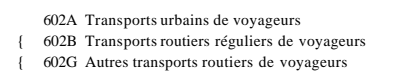 \\
\hline & & 6923 Services de taxis & $602 E$ Transports de voyageurs par taxis \\
\hline & & 6926 Transports par conduites & 603 Transports par conduites \\
\hline \multirow[t]{2}{*}{ Water transport } & Inland water rransport & 70 Navigation intérieure & 612 Transport fluviaux \\
\hline & Maritime transport & 71 Transports maritimes et côtiers & 611 Transports maritimes et côtiers \\
\hline Air transport & Air transport & 72 Transports aériens & 62 Transports aériens \\
\hline \multirow[t]{10}{*}{ Other transport } & Transportation Services & $\begin{array}{l}7302 \text { Ports fluviaux et voies fluviales } \\
73303 \text { Ports maritimes }\end{array}$ & 632C Services portuares, maritimes et fluviaux \\
\hline & & 7304 Aéroports & 632E Services aéroportuaires \\
\hline & & $\begin{array}{l}7305 \text { Exploitation douvrages routiers à péages } \\
7306 \text { Exploitation des parkings }\end{array}$ & 632A Gestion dinfrastructures de transports terrestres \\
\hline & & $\begin{array}{l}7307 \text { Entrepôts autres que frigorifiques } \\
7308 \text { Entrepôts frigorifiques }\end{array}$ & $\begin{array}{l}\text { 631E Entreposage non-frigorifique } \\
\text { 631D Entreposage frigorifique }\end{array}$ \\
\hline & & $\begin{array}{l}\text { 7404 Manutention portuaire } \\
7405 \text { Manutention terrestre et fluvial }\end{array}$ & $\begin{array}{l}\text { 631A Manutention portuaire } \\
631 \mathrm{~B} \text { Manutention non-portuaire }\end{array}$ \\
\hline & & $\begin{array}{l}7401 \text { Collecte de frèt maritime } \\
7402 \text { Collected ed frìt aerien } \\
7403 \text { Collecte de frèt terrestre et fluvial }\end{array}$ & $\begin{array}{l}\text { 634B Affretement } \\
\text { 634A Messagerie, fret express }\end{array}$ \\
\hline & & $\begin{array}{l}7406 \text { Activivitís spécifiques d'auxiliaires des transports } \\
7407 \text { Activitities specifíques d'auxiliaires des transports aeriens }\end{array}$ & 634C Organisation de transports internationaux \\
\hline & & 7409 Agences de voyage & $633 \mathrm{Z}$ Agences de voyage \\
\hline & & \multicolumn{2}{|c|}{$\begin{array}{l}\text { Excluded from transport in NAP: } \\
\text { Excluded from transport in NAF: } \\
\text { NAF }\end{array}$} \\
\hline & & $\begin{array}{l}7410 \text { Routage } \\
7301 \text { Gares routières } \\
7309 \text { Remorquage et pilotage } \\
7408 \text { Autres auxiliares de transports }\end{array}$ & $\begin{array}{l}\text { Excluded from transport in NAF: } \\
\text { Non-matched: }\end{array}$ \\
\hline
\end{tabular}





\section{ANNEX B - SERIES OF Gross FiXed CAPITAL Formation}

\section{SNCF}

The Société National de Chemin de Fer (SNCF) is the main railway company and had until recently the monopoly of rail transport. Five sources on investment and GFCF are available. Firstly, SNCF's annual report (Rapport sur les comptes d'excercise and Bilan Annuell) shows investment in sixteen types of assets both in Paris and surroundings (Ile de France) and the rest of the country. Investment in infrastructure is available only since 1970. Moreover, the report excludes major revisions and leased assets, which accounted for 30 to 50 per cent of total investment.

The second source is INSEE's national accounts, which provide gross fixed capital formation in two types of assets in 1970-76 and nine types from 1977 onwards. These data are the most comprehensive, as they include investment and disposals, major revisions and leased assets. The satellite accounts, a joint effort of INSEE and the Transport Ministry, show total GFCF from 1954 onwards. Moreover, for 1959 to 1967, a breakdown is presented into new investment and major revisions. Unfortunately national and satellite accounts data are poorly documented.

The remaining sources are individual studies, of which the most comprehensive is Quinet et al. (1994). They list investment in four types of infrastructure from 1946 to 1994. Lorentz (1987) shows investments in infrastructure and equipment for the 1971-85 period. Finally, Toutain (1967) presents total investment for the 1846-1950 period.

The investment data presented by INSEE surpass those of the other studies, mainly because INSEE is the only source which includes revisions and leased assets. For the period 1970-97 we therefore used the INSEE data. Total GFCF was extrapolated to 1954 using the satellite accounts data. GFCF in infrastructure for 1962-67 was also taken from the satellite accounts, while the 1946-62 period was estimated by the trend given by Quinet et al. (1994). GFCF in transport equipment in 1954-76 period was estimated by extrapolating the 1977 figure by the trend in investment in transport equipment given by the SNCF.

\section{RATP}

The Régie Autonomne de Transports Parisiens (RATP) provides rail, metro and bus transport in metropolitan Paris (Ile de France). Four sources on investment and GFCF at current prices of the RATP are available. Firstly, the RATP's annual report Rapport d'activité) shows investment in four types of transport equipment, other equipment and infrastructure from 1950 onwards. Major revisions of infrastructure are included but not those of equipment. The report also excludes leased and rented assets, as well as disposals.

The second and most comprehensive source is INSEE's national accounts which show gross fixed capital formation in two asset types in 1970-76 and nine asset types from 1977 
onwards. INSEE includes leased assets and major maintenance. An inconvenience is that INSEE's estimation methods are little transparent. The satellite accounts, co-produced by INSEE and the Transport Ministry, provide data on total investment from 1954 onwards.

The third type of sources available are individual studies: Quinet et al. (1994) show investment in infrastructure from 1960 to 1990, and Lorentz (1987) covers infrastructure and equipment investments in 1971-85.

A comparison shows that Lorentz, Quinet and INSEE's estimates on infrastructure investment are close. Those of RATP are substantially lower, mostly because it excluded several assets. The RATP shows larger investments in rolling stock than INSEE from 1977 to 1992 because the RATP excluded disposals. After 1992, the RATP data are inferior to those of INSEE, which originates from the exclusion of the former of leased equipment.

Our final series of GFCF are those of INSEE for 1977-97. Total and infrastructure GFCF in 1970-76 were also taken from INSEE. The residual was allocated over rolling stock and other equipment using RATP's investment data. Total GFCF in 192-69 was taken from the satellite accounts, and infrastructure investment from Quinet. The residual was allocated over rolling stock and other equipment as for the 1970-76 period. GFCF in 1950-1961 was estimated by extrapolation of the 1962 values by investment series of RATP.

\section{Other Urban ANd InTERURban PASSENGer Transport}

Urban and interurban passenger transport consists of public (except RATP) and private passenger transport by bus, subway and tramway, including taxis. Pipeline transport is also included in this category. The national accounts provide no data on this sector, while the satellite accounts, co-produced by INSEE and the Ministry of Transport, provide data on total investment and disposals in 1970-84, and total investment for the period 1954-69.

GFCF in 1985-97 was estimated using trends on public and private investment. Investment in urban transport (except roads) outside Paris is published by the CERTU (Centre d'Etudes sur les Reseaux, les Transports et l'Urbanisme", in L'annuaire statistique des transports collectifs urbains) from 1995 onwards. For earlier years, the only source on total investment is Lorentz (1987) ${ }^{17}$, which covers the 1971-84 period. Infrastructure investment is available from the satellite accounts from 1980 onwards, and accounted for 60 per cent of total investment (as estimated by CERTU) in 1995 to 1997. Total investment was imputed using this share from 1985 to 1994 . The difference between total and infrastructure investment was allocated over transport and other equipment using the private passenger transport shares.

Investment in private passenger transport is shown in the Enquête annuelle d'entreprise which covers the 1973-96 period. The EAE distinguishes three sub-sectors

${ }^{17}$ Quinet (1994) also shows investment in metro and tramway systems of several cities for 1974-90 period. 
(urban passenger transport, other road passenger transport and taxis) and eight asset types. This survey covered all firms except those with less than 5 employees operating taxi services in the pre-1993 period. Investment data for taxis were only available for 1986, 1989 and 1993 to 1996. The 1993-96 data show that taxi firms with less than five employees accounted for eighty percent of total investment. The same share was used to estimate investment of taxi firms with less than five employees in 1986 and 1989. The years 1987-88 and 1990-92 were interpolated. Investment of all taxi firms from 1973 to 1985 was supposed to grow at the same rate as investment in the other two sub-sectors.

The total GFCF series for 1954-72 were disaggregated over infrastructure, transport and other equipment using the breakdown provided for the 1973-97 period. The data for the recent period show that of 40 per cent of total capital formation was in infrastructure, 50 per cent in transport equipment and 10 per cent in other equipment.

\section{ROAD FREIGHT TRANSPORT}

The national accounts provide no data on gross fixed capital formation in trucking. However, GFCF can be approximated by subtracting disposals from acquisitions as provided by the satellite accounts for the period 1970-96. Investment in trucks, as listed in the satellite accounts, was used to extrapolate the 1970 GFCF figure backwards to 1954 . Trucks accounted for around 85 per cent of total investment, and are therefore representative for overall investment.

A second source is the annual firm survey $E A E$ which distinguishes four sub-sectors (long and short distance trucking, removal companies, and rental companies for trucks and drivers), eight asset types and starts in 1973. For firms with less than five employees, the only breakdown available is between transport equipment and other assets. GFCF by asset type from 1973 to 1996 was estimated by using the EAE investment structure. The average investment shares in infrastructure, transport vehicles and other equipment for the 1973-96 period were applied to disaggregate total GFCF series for 1954-72.

Trucking firms increasingly lease or rent their equipment. Rentals were excluded here as they are mostly for less than a year and therefore are excluded from the capital stock. The ratio of leasing expenses to investment increased from 13 to 44 per cent between 1984 and 1996 (EAE, various issues). The Ministry of Transport $(1995,1998)^{18}$ shows that the share of lease expenditure increased by the same proportion. Lease expenditures were entirely attributed here to GFCF in trucks. They were taken from the EAE and extrapolated back to 1973 using the 1984-93 trend.

\section{Inland Water transport}

Inland water transport is the smallest sector. Moreover, its size, in terms of its relative share in GDP and employment, declined continuously since the 1950s. The national

\footnotetext{
${ }^{18}$ It was supposed that 80 per cent of the leasing expenditure and 70 per cent of rentals corresponded to investment in transport equipment, while the remaining shares represent the cost of finance.
} 
accounts provide no data on GFCF. Instead the satellite accounts provide data on investment and disposals for the period 1979-96, from which GFCF was estimated. No data were available on disposals between 1994-96, but it was assumed that they were the same as the average of 1990-93 (e.g. 60 million francs). Before 1970, total investment is available for 1954-60 and 1965-69. Total investment in 1961-64 was estimated using trends in purchases of vessels. ${ }^{19}$

A second source on investment is the annual firm survey $E A E$, available since 1974, which covers only firms with more than five employees. It provides a breakdown into eight asset types. Missing EAE data were missing for 1977, 1978 and 1981 were estimated by interpolation. The EAE data were used to extrapolate the 1979 GFCF figure to the period 1974-78. GFCF in 1970-73 was estimated by interpolation of the 1969 satellite accounts figure and the $1974 \mathrm{EAE}$ data. Total GFCF data were disaggregated using the asset breakdown of the EAE. Before 1986, the EAE provides no breakdown of investment in infrastructure and other equipment. We used the averages of the 1986-96 shares to estimate investment in each of the two categories, e.g. one third of all investment less transport equipment was in infrastructure and two third was in other equipment.

\section{Maritime Transport}

The national accounts do not provide data on GFCF in maritime transport. Nevertheless, GFCF was estimated from data on investment and disposals in the satellite accounts for the period 1970-96. GFCF was extrapolated to 1962 with satellite accounts data on total investment. No data were available on disposals in 1994-96. They were estimated by the average ratio (e.g. 90 per cent) of disposals to investment in 1992 and 1993.

The EAE distinguishes two sub-sectors, sea and coastal transport. It is available since 1976 and covers only firms of more than five employees. The EAE was used to disaggregate total GFCF over the three asset categories for the period 1976-96: 97 per cent of total investment was in vessels and 3 per cent in other types of equipment. Infrastructure investment was almost zero. These shares were also used to allocate total GFCF over the three asset types in the period 1962-75.

Lorentz (1987) estimated investment in transport equipment which included the purchases of new and second hand ships, transformations and major reparations. His sources include a survey of the organisation of maritime transport (Comité Français des Armateurs de France, CCAF) and the annual firm survey EAE.

Satellite accounts and EAE data are unsuitable to estimate the stock of vessels, mostly because they do not account (or underestimate) the number and value of ships that leave the capital stock. As in the case of aircraft, numerous ships are sold long before their service life ends. Instead the stock of ships was estimated on the basis of administrative records. These registers on paper, maintained by the Secretariat of Maritime Transport, list

\footnotetext{
${ }^{19}$ Data for 1959-60 and 1965 showed that ships accounted for 70 per cent of total investment. This ratio was used to estimate total investment between 1961-64.
} 
all vessels registered in France. The 1970 benchmark stock was estimated using the 1970 complete register with the following characteristics for each vessel: name, previous names, build year, ship type, transport capacity, names of current and former owners. Changes in the stock after 1970 were traced by quarterly published documents of the Transport Ministry showing ships that entered and left the stock, as well as changes of names, owners and transport capacity of vessels present in the stock.

The value of the vessel stock was estimated as follows The new value of vessels was derived Barry Rogliano Salles, which provided price information of vessels built between 1961 and 1998, broken down by vessel type, build year and transport capacity. Price information of ships built before 1961 was derived from various sources: Etude sur les transports maritimes (UNCTAD, various issues), Lloyd's Shipping Economist (Lloyds, various issues) and Fearnleys Review (Fearnleys, various issues). For some vessels, no price information was available. Instead their new value was estimated by prices of similar ships. When prices were not available for a particular build year of a ship, the missing year was estimated by extrapolation using a price deflator of similar ships. The historical construction values were in US\$ and converted to French francs using the current exchange rate. The construction values at current prices were converted to constant prices using price deflators for investment in ships (see section 2.3).

These records include all vessels registered in France no matter in which economic activity they are used (e.g. fishing, maritime transport, etc.). For the purpose of this study, all vessels not owned by firms part of maritime transport had to be excluded. A list of maritime shipping companies was constructed on the basis of four business registers $\left(A S T R E E / D I A N E^{20}\right.$, DAFSALIENS ${ }^{21}$, SIRET and SIRENE ${ }^{22}$ ) Only those ships owned by firms present in at least on one of the registers were retained.

Finally, the gross stock of vessels was estimated by summing the constant replacement values of the vessels. For the estimation of the net stock, it was assumed that the productive capacity of ships decreased linearly over their lifetime. Although the productive capacity of ships probably follows a geometric pattern (see Fraumeni, 1997), we used a linear pattern. This is to compensate for the underestimation of investment in ships as major ship maintenance was not taken into account in our investment data.

\footnotetext{
${ }^{20}$ Database covering balance sheet data of half a million French firms edited by Van Dijk/SCRL.

${ }^{21}$ Database covering 100,000 subsidiaries of the 500 largest French firms edited by DAFSA.

22 SIREN shows the identification number of firms, while SIRET presents identification numbers of establishments. Both databases are managed by INSEE.
} 


\section{Air Transport}

Air transport is the fastest growing branch of transport, in terms of value added, employment, and capital formation. The two major airlines are Air France and Air Inter. The latter was absorbed by Air France in 1997 and renamed Air France Europe. Air France is a public firm, even though a minority share is privatised. Since deregulation in the late 1980s, new companies emerged such as Air Liberté, Air Outre Mer and Nouvelles Frontières. Several sources exist on capital formation. Firstly, INSEE provides GFCF data, broken down by thirteen asset types, for Air France and Air Inter separately since 1977. Total and infrastructure capital formation are also available for the 1970-76 period. INSEE includes both domestic and foreign leased assets. INSEE provides no data on other companies part of air transport. However, their investment in aircraft can be derived implicitly by the difference between GFCF in aircraft of the entire transport sector and that of Air France and Air Inter. INSEE data were used to estimate the stock of infrastructure and other equipment in Air France and Air Inter.

The INSEE data were used to derive a first estimate of the stock of aircraft of all airlines. ${ }^{23}$ However, INSEE data on aircraft are incomplete as they exclude aeroplanes leased by companies other than Air France and Air Inter from foreign firms. These have become increasingly important over time and accounted for almost twenty percent of the value of the stock of aircraft in 1998 (see Section 3). In combination with other shortcomings, discussed in Section 3, administrative records were used in instead of INSEE figures to estimate the stock of aircraft (see below).

The second source is the transport satellite accounts which show GFCF in Air France and Air Inter, and investment and disposals of other air transport companies since 1970. The accounts also show total investment in air transport, used to extrapolate GFCF from 1970 to 1962. Total GFCF in 1962-70 was disaggregated with the average shares of the 1970s: 50 per cent in aircraft and other transport equipment, 10 per cent in other machinery and equipment and 40 per cent in infrastructure.

The third source is balance sheets of Air France and Air Inter (Bilan annuel). Air Inter provides a more detailed asset breakdown than Air France. However, Air France also shows investment whereas Air Inter only publishes stock values. GFCF was estimated by the difference of the stock values of two consecutive years. These data were used to extrapolate GFCF data of Air Inter from 1970 to 1965.

The fourth source is the Annual Firm Survey EAE which covers all air transport firms including Air France and Air Inter. It provides a breakdown into eight asset types. EAE data were used to estimate GFCF in infrastructure and other equipment by airlines other than Air France and Air Inter in 1977-97. Moreover, the 1973 EAE was used to disaggregate total GFCF over the three asset categories for 1970-72.

${ }^{23}$ These series were extrapolated to 1962 using data on total investment in air transport (excluding leases) provided by the satellite accounts. As four-fifth of all investment is in aircraft, as illustrate the 1977-97 series, trends in total investment are representative for investment in aircraft alone. 
The fifth source is administrative records used to estimate the stock of aircraft. The aircraft register, maintained by Airclaims, covers the majority of aircraft operated world-wide since the mid-1950s. Although updated on a monthly basis, we only used the listings of December $31^{\text {st }}$ as aircraft have to figure at least one year in the registers in order to be considered part of the capital stock. Airclaims covers all aircraft operated in France, including leases and rentals. For each aircraft, the following characteristics are available: brand name and category (for example Airbus 319 or Boeing 727); status (on order, in use or in stock); serial number (specific to each model and builder); model; registration number; year of construction; motor type; name of the owner; name of the manager; name of the operator; year of registration. The age of the aircraft is given by the difference between the registration and build year.

The stock of aircraft in air transport was estimated as follows. Firstly, aircraft operated by firms not part of air transport were excluded using annual registers of airlines furnished by the Ministry of Transport. Subsequently the worth of the stock of aircraft had to be estimated, as the Airclaims database provides no information on values. Each aircraft's value was estimated as follows. Firstly, the historical construction cost of each aeroplane, specified by brand, model, build year, and serial number was taken from the Airliner Price Guide. Prices of those models excluded from the Airliner Price Guide were estimated by Airclaims on the basis of other sources or prices of similar aircraft. All prices were in US dollars, and converted to French francs with the current exchange rate (drawn from CEPII's CHELEM database).

Secondly, historical construction prices were converted into constant replacement prices by deflators on investment in aircraft by airlines provided by INSEE for the period 1977-97. These deflators were extrapolated to 1959 by price deflators for investment in aircraft, ship and arms manufacturing. For the 1950-59 period, it was supposed that aircraft prices increased at the same rate as those all transport equipment as given in O'Mahony (1999). Thirdly, the gross stock was estimated by summing the values of all aircraft at constant prices. For the net stock, it was supposed that the value of aircraft decreased constantly over its lifetime (see Section 3 for more details).

\section{Transport Services}

Transport services is a mixture of activities. It contains the operation of large parts of the transport infrastructure: airports and other air navigation systems, canals, car parks, ports, and toll roads. Moreover, this sector includes many supporting services to transport, such as the organisation and handling of goods transport, travel agencies, warehouses, and miscellaneous supporting services.

The national as well as the satellite accounts provide no data on GFCF, acquisitions or disposals of this sector as a whole. However, the satellite accounts provide information on public investment in transport infrastructure such as airports, canals, ports and toll roads. These series start at different dates between 1965 and 1980. Other sources on infrastructure investment include organisations such as Aéroports de Paris (owner and operator of the 
Charles de Gaulle and Orly airports), and specific studies such as Quinet et al. (1994) who estimated investment in canals and ports.

Investment by goods handling services, travel agencies ${ }^{24}$ and non-refrigerated warehouses $^{25}$ can be estimated using data of the annual enterprise survey EAE for the period 1982-96. No data are available for miscellaneous supporting services.

\footnotetext{
${ }^{24}$ Investment data from started only in 1982. For the period 1973-81, it was assumed that infrastructure investment by travel agencies as a share of total infrastructure investment in transport services was the same as the period 1982-95. Investment in transport and other equipment from 1973 to 1981 was estimated by assuming that their proportion to investment in infrastructure was the same as for the 198296 period: 16 and 50 per cent respectively.

${ }^{25}$ Non-refrigerated warehouses were included in the EAE only since 1993. The data for the 1993-96 period show that investment in infrastructure represented 3 per cent of total investment. This share has been assumed representative for the periods 1973-92 and 1997-98. Investment in transport and other equipment from 1973-92 was estimated by assuming that their proportion to investment in infrastructure was the same as for the 1993-96 period: 13 and 25 per cent respectively.
} 
Annex C - Capital Formation at Constant and Current Prices 
Table C.1: Gross Fixed Capital Formation at Current \& Constant Prices, SNCF

\begin{tabular}{|c|c|c|c|c|c|c|c|c|}
\hline & \multicolumn{4}{|c|}{$\begin{array}{c}\text { Gross fixed capital formation at current } \\
\text { prices (million French francs) }\end{array}$} & \multicolumn{4}{|c|}{$\begin{array}{l}\text { Gross fixed capital formation at constant } \\
\text { prices (million } 1980 \text { French francs) }\end{array}$} \\
\hline & TOTAL & $\begin{array}{c}\text { Non- } \\
\text { residentia } \\
\quad 1 \\
\text { structures }\end{array}$ & $\begin{array}{l}\text { Transport } \\
\text { equipment }\end{array}$ & $\begin{array}{c}\text { Other } \\
\text { machinery } \\
\& \\
\text { equipment }\end{array}$ & TOTAL & $\begin{array}{c}\text { Non- } \\
\text { residentia } \\
1 \\
\text { structures }\end{array}$ & $\begin{array}{l}\text { Transport } \\
\text { equipment }\end{array}$ & $\begin{array}{c}\text { Other } \\
\text { machinery } \\
\& \\
\text { equipment }\end{array}$ \\
\hline 1946 & & 487 & & & & 4419 & & \\
\hline 1947 & & 686 & & & & 6231 & & \\
\hline 1948 & & 595 & & & & 5401 & & \\
\hline 1949 & & 664 & & & & 6027 & & \\
\hline 1950 & 1042 & 531 & 383 & 128 & 7961 & 4825 & 2288 & 847 \\
\hline 1951 & 727 & 403 & 243 & 81 & 4568 & 3040 & 1115 & 413 \\
\hline 1952 & 519 & 410 & 82 & 27 & 2892 & 2471 & 307 & 114 \\
\hline 1953 & 1004 & 535 & 352 & 117 & 5256 & 3260 & 1457 & 539 \\
\hline 1954 & 1897 & 589 & 544 & 764 & 9471 & 3589 & 2299 & 3583 \\
\hline 1955 & 1777 & 819 & 666 & 293 & 8977 & 4854 & 2771 & 1352 \\
\hline 1956 & 1818 & 904 & 814 & 99 & 8787 & 5153 & 3202 & 433 \\
\hline 1957 & 2008 & 837 & 996 & 174 & 8848 & 4392 & 3730 & 725 \\
\hline 1958 & 2214 & 1011 & 1082 & 121 & 8855 & 4909 & 3509 & 437 \\
\hline 1959 & 2352 & 1057 & 1658 & 304 & 10982 & 4947 & 5014 & 1020 \\
\hline 1960 & 2552 & 1134 & 933 & 486 & 9586 & 5249 & 2760 & 1577 \\
\hline 1961 & 2600 & 1054 & 959 & 587 & 9149 & 4587 & 2700 & 1862 \\
\hline 1962 & 2648 & 1324 & 996 & 328 & 9226 & 5471 & 2743 & 1012 \\
\hline 1963 & 2944 & 1522 & 1045 & 377 & 9764 & 5849 & 2794 & 1120 \\
\hline 1964 & 3357 & 1547 & 1219 & 591 & 10600 & 5625 & 3254 & 1722 \\
\hline 1965 & 3564 & 1498 & 1481 & 585 & 10919 & 5298 & 3958 & 1663 \\
\hline 1966 & 3627 & 1529 & 1608 & 490 & 10840 & 5269 & 4200 & 1370 \\
\hline 1967 & 3669 & 1578 & 1639 & 452 & 10740 & 5249 & 4269 & 1223 \\
\hline 1968 & 3479 & 1668 & 1276 & 535 & 10363 & 5266 & 3554 & 1544 \\
\hline 1969 & 3451 & 1763 & 1142 & 546 & 9925 & 5332 & 3066 & 1527 \\
\hline 1970 & 3514 & 1863 & 1174 & 477 & 9502 & 5276 & 3004 & 1222 \\
\hline 1971 & 3512 & 1887 & 1208 & 416 & 8902 & 5017 & 2888 & 997 \\
\hline 1972 & 3264 & 1555 & 1345 & 364 & 7749 & 3880 & 3045 & 824 \\
\hline 1973 & 3930 & 1737 & 1503 & 690 & 8733 & 3962 & 3268 & 1503 \\
\hline 1974 & 4723 & 2098 & 1997 & 628 & 9157 & 4129 & 3824 & 1204 \\
\hline 1975 & 6077 & 2533 & 2509 & 1035 & 10273 & 4392 & 4161 & 1720 \\
\hline 1976 & 6657 & 2653 & 2828 & 1176 & 10078 & 4089 & 4228 & 1761 \\
\hline 1977 & 7618 & 3364 & 3431 & 823 & 10327 & 4613 & 4607 & 1107 \\
\hline 1978 & 8683 & 4314 & 3492 & 877 & 10906 & 5441 & 4376 & 1089 \\
\hline 1979 & 9238 & 4851 & 3433 & 954 & 10489 & 5538 & 3881 & 1070 \\
\hline 1980 & 10668 & 5678 & 3810 & 1180 & 10668 & 5678 & 3810 & 1180 \\
\hline 1981 & 12701 & 6352 & 4914 & 1435 & 11405 & 5749 & 4351 & 1305 \\
\hline 1982 & 13260 & 6659 & 5109 & 1492 & 10679 & 5415 & 4035 & 1229 \\
\hline 1983 & 14314 & 6974 & 5681 & 1659 & 10564 & 5270 & 4062 & 1232 \\
\hline 1984 & 13853 & 6997 & 5190 & 1666 & 9638 & 4967 & 3512 & 1159 \\
\hline 1985 & 13388 & 6693 & 5070 & 1625 & 8866 & 4524 & 3272 & 1070 \\
\hline 1986 & 15800 & 8064 & 5860 & 1876 & 10194 & 5320 & 3678 & 1196 \\
\hline 1987 & 15594 & 8970 & 4985 & 1639 & 9922 & 5738 & 3164 & 1020 \\
\hline 1988 & 18192 & 9321 & 6779 & 2092 & 10921 & 5778 & 3899 & 1244 \\
\hline 1989 & 18107 & 9277 & 6757 & 2073 & 10731 & 5606 & 3938 & 1187 \\
\hline 1990 & 23117 & 11844 & 8652 & 2621 & 13369 & 6991 & 4898 & 1480 \\
\hline 1991 & 27354 & 14114 & 10176 & 3064 & 15219 & 8010 & 5492 & 1717 \\
\hline 1992 & 30148 & 12833 & 13332 & 3983 & 16559 & 7185 & 7131 & 2243 \\
\hline 1993 & 24272 & 12926 & 8715 & 2631 & 13148 & 7138 & 4509 & 1501 \\
\hline 1994 & 20404 & 10102 & 7913 & 2389 & 10799 & 5530 & 3911 & 1358 \\
\hline 1995 & 19286 & 9718 & 7351 & 2217 & 10185 & 5258 & 3679 & 1248 \\
\hline 1996 & 22953 & 10664 & 9453 & 2836 & 12090 & 5699 & 4773 & 1618 \\
\hline
\end{tabular}




\begin{tabular}{rrrrrrrrr}
1997 & 22957 & 8235 & 11333 & 3389 & 12200 & 4333 & 5963 & 1904 \\
\hline
\end{tabular}

\section{Table C.2: Gross Fixed Capital Formation at Current \& Constant Prices, RATP}

\begin{tabular}{|c|c|c|c|c|c|c|c|c|}
\hline & \multicolumn{4}{|c|}{$\begin{array}{c}\text { Gross fixed capital formation at current } \\
\text { prices (million French francs) }\end{array}$} & \multicolumn{4}{|c|}{$\begin{array}{c}\text { Gross fixed capital formation at constant } \\
\text { prices (million } 1980 \text { French francs) }\end{array}$} \\
\hline & TOTAL & $\begin{array}{c}\text { Non- } \\
\text { residentia } \\
l \\
\text { structures }\end{array}$ & $\begin{array}{l}\text { Transport } \\
\text { equipment }\end{array}$ & $\begin{array}{c}\text { Other } \\
\text { machinery } \\
\& \\
\text { equipment }\end{array}$ & TOTAL & $\begin{array}{c}\text { Non- } \\
\text { residentia } \\
1 \\
\text { structures }\end{array}$ & $\begin{array}{l}\text { Transport } \\
\text { equipment }\end{array}$ & $\begin{array}{c}\text { Other } \\
\text { machinery } \\
\& \\
\text { equipment }\end{array}$ \\
\hline 1950 & 78 & 71 & 7 & 1 & 583 & 511 & 65 & 7 \\
\hline 1951 & 51 & 39 & 11 & 1 & 323 & 233 & 84 & 6 \\
\hline 1952 & 80 & 68 & 10 & 2 & 402 & 327 & 59 & 15 \\
\hline 1953 & 57 & 41 & 13 & 2 & 309 & 200 & 89 & 20 \\
\hline 1954 & 153 & 135 & 14 & 3 & 784 & 654 & 99 & 31 \\
\hline 1955 & 117 & 91 & 24 & 2 & 611 & 429 & 161 & 21 \\
\hline 1956 & 86 & 52 & 31 & 2 & 455 & 235 & 200 & 19 \\
\hline 1957 & 48 & 9 & 37 & 3 & 280 & 36 & 222 & 21 \\
\hline 1958 & 118 & 72 & 42 & 4 & 527 & 278 & 220 & 29 \\
\hline 1959 & 88 & 34 & 52 & 3 & 399 & 126 & 254 & 19 \\
\hline 1960 & 76 & 52 & 14 & 10 & 323 & 191 & 69 & 63 \\
\hline 1961 & 106 & 83 & 6 & 17 & 418 & 288 & 29 & 101 \\
\hline 1962 & 174 & 136 & 10 & 28 & 658 & 448 & 43 & 167 \\
\hline 1963 & 233 & 139 & 54 & 41 & 887 & 425 & 233 & 229 \\
\hline 1964 & 234 & 181 & 23 & 31 & 792 & 524 & 98 & 170 \\
\hline 1965 & 394 & 283 & 74 & 37 & 1320 & 798 & 322 & 200 \\
\hline 1966 & 603 & 443 & 108 & 51 & 1951 & 1218 & 460 & 273 \\
\hline 1967 & 764 & 578 & 123 & 63 & 2378 & 1533 & 520 & 325 \\
\hline 1968 & 921 & 707 & 119 & 95 & 2839 & 1781 & 536 & 521 \\
\hline 1969 & 960 & 724 & 124 & 111 & 2881 & 1748 & 541 & 593 \\
\hline 1970 & 798 & 719 & 49 & 30 & 1974 & 1624 & 204 & 145 \\
\hline 1971 & 852 & 792 & 43 & 17 & 1916 & 1545 & 251 & 121 \\
\hline 1972 & 887 & 751 & 88 & 48 & 1698 & 1194 & 305 & 198 \\
\hline 1973 & 1219 & 1032 & 133 & 54 & 1834 & 1220 & 415 & 200 \\
\hline 1974 & 1321 & 1100 & 153 & 68 & 1921 & 1271 & 426 & 224 \\
\hline 1975 & 1465 & 1173 & 201 & 91 & 2112 & 1352 & 496 & 264 \\
\hline 1976 & 1708 & 1386 & 226 & 96 & 2031 & 1259 & 516 & 256 \\
\hline 1977 & 1861 & 1577 & 236 & 48 & 2121 & 1420 & 566 & 135 \\
\hline 1978 & 1811 & 1588 & 208 & 15 & 2345 & 1675 & 538 & 133 \\
\hline 1979 & 2005 & 1586 & 325 & 94 & 2312 & 1705 & 477 & 131 \\
\hline 1980 & 2360 & 1748 & 468 & 144 & 2360 & 1748 & 468 & 144 \\
\hline 1981 & 2251 & 1556 & 547 & 148 & 2464 & 1770 & 534 & 159 \\
\hline 1982 & 2456 & 1639 & 643 & 174 & 2313 & 1667 & 496 & 150 \\
\hline 1983 & 2443 & 2023 & 329 & 91 & 2272 & 1622 & 499 & 150 \\
\hline 1984 & 2087 & 2018 & 53 & 16 & 2102 & 1529 & 431 & 141 \\
\hline 1985 & 2684 & 1872 & 639 & 173 & 1925 & 1393 & 402 & 131 \\
\hline 1986 & 2197 & 1852 & 271 & 74 & 2236 & 1638 & 452 & 146 \\
\hline 1987 & 2659 & 1558 & 869 & 232 & 2280 & 1766 & 389 & 124 \\
\hline 1988 & 2321 & 2074 & 190 & 57 & 2410 & 1779 & 479 & 152 \\
\hline 1989 & 2209 & 1974 & 180 & 55 & 2354 & 1726 & 484 & 145 \\
\hline 1990 & 3240 & 2895 & 269 & 76 & 2934 & 2152 & 602 & 181 \\
\hline 1991 & 3456 & 3101 & 277 & 78 & 3350 & 2466 & 675 & 210 \\
\hline 1992 & 3873 & 2820 & 837 & 216 & 3362 & 2212 & 876 & 274 \\
\hline 1993 & 5070 & 2840 & 1779 & 451 & 2935 & 2197 & 554 & 183 \\
\hline 1994 & 4983 & 2220 & 2200 & 563 & 2349 & 1702 & 480 & 166 \\
\hline 1995 & 5680 & 2135 & 2827 & 718 & 2223 & 1619 & 452 & 152 \\
\hline 1996 & 4985 & 2342 & 2091 & 552 & 2538 & 1754 & 586 & 197 \\
\hline 1997 & 5147 & 1809 & 2655 & 683 & 2299 & 1334 & 732 & 232 \\
\hline
\end{tabular}


Capital Stock and Productivity in French Transport : An International Comparison 
Table C.3: Gross Fixed Capital Formation at Current \& Constant Prices, Other Urban and Interurban Passenger Transport (excl. RATP)

\begin{tabular}{|c|c|c|c|c|c|c|c|c|}
\hline & \multicolumn{4}{|c|}{$\begin{array}{c}\text { Gross fixed capital formation at current } \\
\text { prices (million French francs) }\end{array}$} & \multicolumn{4}{|c|}{$\begin{array}{c}\text { Gross fixed capital formation at constant } \\
\text { prices (million } 1980 \text { French francs) }\end{array}$} \\
\hline & TOTAL & $\begin{array}{c}\text { Non- } \\
\text { residentia } \\
\text { l } \\
\text { structures }\end{array}$ & $\begin{array}{l}\text { Transport } \\
\text { equipment }\end{array}$ & $\begin{array}{c}\text { Other } \\
\text { machinery } \\
\& \\
\text { equipment }\end{array}$ & TOTAL & $\begin{array}{c}\text { Non- } \\
\text { residentia } \\
l \\
\text { structures }\end{array}$ & $\begin{array}{l}\text { Transport } \\
\text { equipment }\end{array}$ & $\begin{array}{c}\text { Other } \\
\text { machinery } \\
\& \\
\text { equipment }\end{array}$ \\
\hline 1954 & 136 & 54 & 68 & 14 & 731 & 390 & 279 & 62 \\
\hline 1955 & 145 & 58 & 73 & 15 & 776 & 418 & 292 & 65 \\
\hline 1956 & 160 & 64 & 80 & 16 & 761 & 388 & 305 & 68 \\
\hline 1957 & 174 & 70 & 87 & 17 & 775 & 389 & 316 & 71 \\
\hline 1958 & 193 & 77 & 97 & 19 & 750 & 378 & 303 & 68 \\
\hline 1959 & 234 & 94 & 117 & 23 & 851 & 431 & 343 & 77 \\
\hline 1960 & 252 & 101 & 126 & 25 & 901 & 460 & 361 & 80 \\
\hline 1961 & 267 & 107 & 133 & 27 & 919 & 473 & 364 & 82 \\
\hline 1962 & 308 & 123 & 154 & 31 & 1,023 & 518 & 411 & 93 \\
\hline 1963 & 342 & 137 & 171 & 34 & 1,069 & 527 & 443 & 99 \\
\hline 1964 & 342 & 137 & 171 & 34 & 1,035 & 496 & 442 & 97 \\
\hline 1965 & 350 & 140 & 175 & 35 & 1,033 & 483 & 453 & 97 \\
\hline 1966 & 385 & 154 & 193 & 39 & 1,109 & 516 & 487 & 105 \\
\hline 1967 & 415 & 166 & 208 & 42 & 1,179 & 546 & 524 & 110 \\
\hline 1968 & 456 & 182 & 228 & 46 & 1,315 & 572 & 615 & 128 \\
\hline 1969 & 506 & 202 & 253 & 51 & 1,390 & 594 & 658 & 138 \\
\hline 1970 & 529 & 212 & 265 & 53 & 1,387 & 599 & 656 & 132 \\
\hline 1971 & 1,094 & 438 & 547 & 109 & 2,683 & 1,164 & 1,265 & 255 \\
\hline 1972 & 1,989 & 796 & 995 & 199 & 4,606 & 1,985 & 2,181 & 439 \\
\hline 1973 & 1,782 & 479 & 1,099 & 204 & 3,947 & 1,093 & 2,404 & 450 \\
\hline 1974 & 1,003 & 391 & 533 & 79 & 1,944 & 770 & 1,022 & 153 \\
\hline 1975 & 1,522 & 644 & 766 & 112 & 2,606 & 1,117 & 1,298 & 191 \\
\hline 1976 & 2,266 & 862 & 1,337 & 67 & 3,439 & 1,328 & 2,009 & 101 \\
\hline 1977 & 4,597 & 1,778 & 2,643 & 176 & 6,268 & 2,438 & 3,589 & 241 \\
\hline 1978 & 1,943 & 646 & 1,213 & 84 & 2,435 & 815 & 1,516 & 104 \\
\hline 1979 & 3,238 & 1,596 & 1,569 & 73 & 3,670 & 1,822 & 1,765 & 83 \\
\hline 1980 & 2,477 & 1,042 & 1,370 & 65 & 2,477 & 1,042 & 1,370 & 65 \\
\hline 1981 & 2,427 & 1,072 & 1,303 & 52 & 2,200 & 970 & 1,183 & 47 \\
\hline 1982 & 2,507 & 1,563 & 878 & 66 & 2,041 & 1,271 & 718 & 52 \\
\hline 1983 & 2,851 & 1,531 & 1,187 & 133 & 2,141 & 1,157 & 888 & 96 \\
\hline 1984 & 2,600 & 1,342 & 992 & 266 & 1,848 & 953 & 714 & 181 \\
\hline 1985 & 4,265 & 2,173 & 1,589 & 503 & 2,894 & 1,469 & 1,100 & 325 \\
\hline 1986 & 3,406 & 1,382 & 1,560 & 464 & 2,200 & 912 & 1,002 & 286 \\
\hline 1987 & 3,512 & 1,509 & 1,569 & 434 & 2,188 & 964 & 965 & 259 \\
\hline 1988 & 3,389 & 1,249 & 1,601 & 539 & 2,052 & 773 & 961 & 318 \\
\hline 1989 & 3,229 & 971 & 1,627 & 631 & 1,876 & 585 & 931 & 360 \\
\hline 1990 & 3,326 & 983 & 1,621 & 722 & 1,874 & 579 & 897 & 398 \\
\hline 1991 & 3,646 & 1,117 & 1,750 & 779 & 1,981 & 633 & 939 & 410 \\
\hline 1992 & 5,299 & 2,351 & 1,905 & 1,043 & 2,844 & 1,315 & 986 & 543 \\
\hline 1993 & 4,427 & 1,214 & 2,377 & 836 & 2,341 & 670 & 1,235 & 437 \\
\hline 1994 & 4,820 & 1,413 & 2,460 & 947 & 2,513 & 772 & 1,239 & 502 \\
\hline 1995 & 4,231 & 1,129 & 2,106 & 997 & 2,153 & 610 & 1,014 & 529 \\
\hline 1996 & 4,955 & 1,807 & 2,293 & 855 & 2,524 & 964 & 1,109 & 451 \\
\hline
\end{tabular}


Table C.4: Gross Fixed Capital Formation at Current \& Constant Prices, Road Goods Transport

\begin{tabular}{|c|c|c|c|c|c|c|c|c|}
\hline & \multicolumn{4}{|c|}{$\begin{array}{c}\text { Gross fixed capital formation at current } \\
\text { prices (million French francs) }\end{array}$} & \multicolumn{4}{|c|}{$\begin{array}{c}\text { Gross fixed capital formation at constant } \\
\text { prices (million } 1980 \text { French francs) }\end{array}$} \\
\hline & TOTAL & $\begin{array}{c}\text { Non- } \\
\text { residentia } \\
\text { l } \\
\text { structures }\end{array}$ & $\begin{array}{l}\text { Transport } \\
\text { equipment }\end{array}$ & $\begin{array}{c}\text { Other } \\
\text { machinery } \\
\& \\
\text { equipment }\end{array}$ & TOTAL & $\begin{array}{c}\text { Non- } \\
\text { residentia } \\
\text { l } \\
\text { structures }\end{array}$ & $\begin{array}{l}\text { Transport } \\
\text { equipment }\end{array}$ & $\begin{array}{c}\text { Other } \\
\text { machinery } \\
\& \\
\text { equipment }\end{array}$ \\
\hline 1954 & 138 & 14 & 96 & 28 & 620 & 99 & 395 & 126 \\
\hline 1955 & 173 & 17 & 121 & 35 & 770 & 125 & 489 & 156 \\
\hline 1956 & 201 & 20 & 141 & 40 & 830 & 122 & 537 & 171 \\
\hline 1957 & 238 & 24 & 166 & 48 & 929 & 133 & 604 & 193 \\
\hline 1958 & 254 & 25 & 178 & 51 & 862 & 125 & 559 & 178 \\
\hline 1959 & 271 & 27 & 190 & 54 & 860 & 125 & 557 & 178 \\
\hline 1960 & 295 & 29 & 206 & 59 & 912 & 134 & 591 & 186 \\
\hline 1961 & 363 & 36 & 254 & 73 & 1,078 & 161 & 693 & 224 \\
\hline 1962 & 396 & 40 & 277 & 79 & 1,145 & 166 & 740 & 238 \\
\hline 1963 & 480 & 48 & 336 & 96 & 1,334 & 185 & 871 & 278 \\
\hline 1964 & 545 & 55 & 382 & 109 & 1,495 & 198 & 988 & 310 \\
\hline 1965 & 507 & 51 & 355 & 101 & 1,376 & 175 & 920 & 281 \\
\hline 1966 & 558 & 56 & 391 & 112 & 1,480 & 187 & 989 & 304 \\
\hline 1967 & 602 & 60 & 421 & 120 & 1,578 & 198 & 1,063 & 317 \\
\hline 1968 & 661 & 66 & 463 & 132 & 1,828 & 207 & 1,249 & 372 \\
\hline 1969 & 733 & 73 & 513 & 147 & 1,951 & 215 & 1,336 & 400 \\
\hline 1970 & 820 & 82 & 574 & 164 & 2,066 & 232 & 1,424 & 410 \\
\hline 1971 & 969 & 97 & 678 & 194 & 2,277 & 258 & 1,568 & 451 \\
\hline 1972 & 1,207 & 121 & 845 & 241 & 2,688 & 301 & 1,853 & 533 \\
\hline 1973 & 1,536 & 127 & 906 & 504 & 3,382 & 290 & 1,981 & 1,111 \\
\hline 1974 & 1,521 & 123 & 929 & 469 & 2,929 & 242 & 1,781 & 906 \\
\hline 1975 & 1,157 & 65 & 683 & 409 & 1,968 & 112 & 1,157 & 698 \\
\hline 1976 & 1,990 & 78 & 1,787 & 125 & 2,994 & 121 & 2,684 & 189 \\
\hline 1977 & 2,295 & 111 & 2,034 & 150 & 3,121 & 153 & 2,762 & 206 \\
\hline 1978 & 2,422 & 93 & 2,161 & 167 & 3,025 & 118 & 2,701 & 207 \\
\hline 1979 & 2,116 & 119 & 1,878 & 120 & 2,383 & 135 & 2,112 & 136 \\
\hline 1980 & 2,931 & 182 & 2,570 & 179 & 2,931 & 182 & 2,570 & 179 \\
\hline 1981 & 2,575 & 158 & 2,268 & 148 & 2,335 & 143 & 2,059 & 133 \\
\hline 1982 & 3,567 & 193 & 3,157 & 217 & 2,909 & 157 & 2,582 & 169 \\
\hline 1983 & 3,638 & 197 & 3,183 & 258 & 2,716 & 149 & 2,382 & 186 \\
\hline 1984 & 3,906 & 195 & 3,445 & 265 & 2,797 & 139 & 2,478 & 181 \\
\hline 1985 & 3,575 & 137 & 3,184 & 255 & 2,462 & 93 & 2,205 & 164 \\
\hline 1986 & 4,794 & 230 & 4,174 & 390 & 3,073 & 152 & 2,682 & 240 \\
\hline 1987 & 6,211 & 338 & 5,389 & 483 & 3,819 & 216 & 3,315 & 288 \\
\hline 1988 & 7,068 & 412 & 6,125 & 531 & 4,246 & 255 & 3,677 & 314 \\
\hline \multirow[t]{2}{*}{1989} & & 586 & 8,888 & 713 & 5,842 & 353 & 5,082 & 407 \\
\hline & 10,187 & & & & & & & \\
\hline 1990 & 7,738 & 434 & 6,840 & 463 & 4,296 & 256 & 3,784 & 256 \\
\hline 1991 & 6,929 & 336 & 6,298 & 295 & 3,724 & 190 & 3,379 & 155 \\
\hline \multirow[t]{2}{*}{1992} & & 359 & 9,613 & 689 & 5,536 & 201 & 4,977 & 359 \\
\hline & 10,660 & & & & & & & \\
\hline 1993 & 9,121 & 265 & 8,325 & 532 & 4,749 & 146 & 4,325 & 278 \\
\hline 1994 & 9,427 & 446 & 8,441 & 540 & 4,780 & 244 & 4,249 & 287 \\
\hline 1995 & & 710 & 11,250 & 885 & 6,269 & 384 & 5,416 & 469 \\
\hline
\end{tabular}


CEPII - Working Paper $n^{\circ} 00-18$

\begin{tabular}{lllllllll}
\hline & & & & & & & \\
1996 & 855 & 9,530 & 547 & 5,355 & 456 & 4,610 & 289 \\
& 10,933 & & & & & & \\
\hline
\end{tabular}


Table C.5: Gross Fixed Capital Formation at Current \& Constant Prices, Inland Water Transport

\begin{tabular}{|c|c|c|c|c|c|c|c|c|}
\hline & \multicolumn{4}{|c|}{$\begin{array}{c}\text { Gross fixed capital formation at current } \\
\text { prices (million French francs) }\end{array}$} & \multicolumn{4}{|c|}{$\begin{array}{c}\text { Gross fixed capital formation at constant } \\
\text { prices (million } 1980 \text { French francs) }\end{array}$} \\
\hline & TOTAL & $\begin{array}{c}\text { Non- } \\
\text { residentia } \\
\text { l } \\
\text { structures }\end{array}$ & $\begin{array}{c}\text { Transport } \\
\text { equipment }\end{array}$ & $\begin{array}{c}\text { Other } \\
\text { machinery } \\
\& \\
\text { equipment }\end{array}$ & TOTAL & $\begin{array}{c}\text { Non- } \\
\text { residentia } \\
l \\
\text { structures }\end{array}$ & $\begin{array}{c}\text { Transport } \\
\text { equipment }\end{array}$ & $\begin{array}{c}\text { Other } \\
\text { machinery } \\
\& \\
\text { equipment }\end{array}$ \\
\hline 1954 & 34 & 3 & 24 & 7 & 148 & 24 & 93 & 31 \\
\hline 1955 & 42 & 4 & 29 & 8 & 181 & 30 & 113 & 38 \\
\hline 1956 & 42 & 4 & 29 & 8 & 168 & 25 & 107 & 36 \\
\hline 1957 & 51 & 5 & 36 & 10 & 193 & 28 & 123 & 41 \\
\hline 1958 & 60 & 6 & 42 & 12 & 197 & 29 & 126 & 42 \\
\hline 1959 & 65 & 3 & 57 & 5 & 189 & 12 & 159 & 17 \\
\hline 1960 & 57 & 7 & 37 & 13 & 176 & 30 & 104 & 42 \\
\hline 1961 & 61 & 6 & 43 & 12 & 184 & 27 & 118 & 38 \\
\hline 1962 & 61 & 6 & 43 & 12 & 181 & 26 & 118 & 37 \\
\hline 1963 & 80 & 8 & 56 & 16 & 230 & 31 & 152 & 46 \\
\hline 1964 & 73 & 7 & 51 & 15 & 208 & 26 & 140 & 41 \\
\hline 1965 & 73 & 6 & 56 & 11 & 203 & 20 & 152 & 31 \\
\hline 1966 & 72 & 7 & 50 & 14 & 198 & 24 & 135 & 39 \\
\hline 1967 & 72 & 7 & 50 & 14 & 195 & 24 & 133 & 38 \\
\hline 1968 & 75 & 8 & 53 & 15 & 205 & 24 & 139 & 42 \\
\hline 1969 & 85 & 9 & 60 & 17 & 225 & 25 & 154 & 46 \\
\hline 1970 & 54 & 5 & 38 & 11 & 136 & 15 & 94 & 27 \\
\hline 1971 & 34 & 3 & 24 & 7 & 81 & 9 & 56 & 16 \\
\hline 1972 & 22 & 2 & 15 & 4 & 48 & 5 & 33 & 10 \\
\hline 1973 & 14 & 1 & 10 & 3 & 30 & 3 & 21 & 6 \\
\hline 1974 & 9 & 0 & 8 & 0 & 17 & 0 & 16 & 1 \\
\hline 1975 & 20 & 3 & 11 & 6 & 34 & 5 & 18 & 10 \\
\hline 1976 & 22 & 0 & 21 & 1 & 33 & 0 & 31 & 1 \\
\hline 1977 & 21 & 1 & 18 & 2 & 29 & 1 & 25 & 3 \\
\hline 1978 & 21 & 2 & 15 & 3 & 24 & 2 & 17 & 4 \\
\hline 1979 & 20 & 2 & 13 & 4 & 24 & 3 & 16 & 5 \\
\hline 1980 & 26 & 2 & 19 & 5 & 26 & 2 & 19 & 5 \\
\hline 1981 & 67 & 6 & 49 & 12 & 60 & 5 & 44 & 11 \\
\hline 1982 & 55 & 5 & 40 & 10 & 43 & 4 & 32 & 8 \\
\hline 1983 & 138 & 20 & 79 & 40 & 97 & 15 & 54 & 28 \\
\hline 1984 & 96 & 6 & 78 & 12 & 77 & 4 & 64 & 8 \\
\hline 1985 & -41 & -1 & -38 & -2 & -31 & -1 & -29 & -1 \\
\hline 1986 & 11 & 1 & 7 & 3 & 7 & 1 & 5 & 2 \\
\hline 1987 & 146 & 9 & 125 & 11 & 100 & 6 & 87 & 7 \\
\hline 1988 & -12 & -1 & -10 & -0 & -4 & -1 & -3 & -0 \\
\hline 1989 & 98 & 13 & 81 & 5 & 109 & 8 & 99 & 3 \\
\hline 1990 & 91 & 13 & 63 & 15 & 95 & 8 & 79 & 8 \\
\hline 1991 & 123 & 5 & 101 & 18 & 124 & 3 & 112 & 9 \\
\hline 1992 & 244 & 10 & 147 & 86 & 208 & 6 & 158 & 45 \\
\hline 1993 & 175 & 39 & 67 & 69 & 125 & 22 & 67 & 36 \\
\hline 1994 & 164 & 23 & 76 & 66 & 118 & 12 & 71 & 35 \\
\hline 1995 & 177 & 9 & 70 & 97 & 123 & 5 & 67 & 52 \\
\hline 1996 & 152 & 7 & 34 & 111 & 95 & 4 & 33 & 59 \\
\hline
\end{tabular}


Table C.6: Gross Fixed Capital Formation at Current \& Constant Prices, Maritime Transport

\begin{tabular}{|c|c|c|c|c|c|c|c|c|}
\hline & \multicolumn{4}{|c|}{$\begin{array}{c}\text { Gross fixed capital formation at current } \\
\text { prices (million French francs) }\end{array}$} & \multicolumn{4}{|c|}{$\begin{array}{l}\text { Gross fixed capital formation at constant } \\
\text { prices (million } 1980 \text { French francs) }\end{array}$} \\
\hline & TOTAL & $\begin{array}{c}\text { Non- } \\
\text { residentia } \\
\text { l } \\
\text { structures }\end{array}$ & $\begin{array}{l}\text { Transport } \\
\text { equipment } \\
*\end{array}$ & $\begin{array}{c}\text { Other } \\
\text { machinery } \\
\& \\
\text { equipment }\end{array}$ & TOTAL & $\begin{array}{c}\text { Non- } \\
\text { residentia } \\
\text { l } \\
\text { structures }\end{array}$ & $\begin{array}{c}\text { Transport } \\
\text { equipment } \\
*\end{array}$ & $\begin{array}{c}\text { Other } \\
\text { machinery } \\
\& \\
\text { equipment } \\
\end{array}$ \\
\hline 1962 & 476 & & 461 & 14 & 1,310 & & 1,267 & 43 \\
\hline 1963 & 229 & & 222 & 7 & 623 & & 604 & 20 \\
\hline 1964 & 347 & & 337 & 10 & 955 & & 926 & 30 \\
\hline 1965 & 353 & & 343 & 11 & 963 & & 933 & 29 \\
\hline 1966 & 457 & & 444 & 14 & 1,226 & & 1,188 & 37 \\
\hline 1967 & 410 & & 397 & 12 & 1,083 & & 1,051 & 32 \\
\hline 1968 & 446 & & 432 & 13 & 1,182 & & 1,145 & 38 \\
\hline 1969 & 501 & & 486 & 15 & 1,298 & & 1,257 & 41 \\
\hline 1970 & 728 & & 706 & 22 & 1,818 & & 1,763 & 55 \\
\hline 1971 & 1,453 & & 1,409 & 44 & 3,382 & & 3,280 & 102 \\
\hline 1972 & 714 & & 693 & 21 & 1,576 & & 1,529 & 47 \\
\hline 1973 & 1,746 & & 1,694 & 52 & 3,846 & & 3,730 & 115 \\
\hline 1974 & 2,062 & & 2,000 & 62 & 3,981 & & 3,861 & 120 \\
\hline 1975 & 2,364 & & 2,293 & 71 & 4,033 & & 3,912 & 121 \\
\hline 1976 & 1,963 & & 1,911 & 52 & 2,968 & & 2,890 & 78 \\
\hline 1977 & 1,984 & & 1,929 & 55 & 2,712 & & 2,637 & 75 \\
\hline 1978 & 1,810 & & 1,720 & 90 & 2,047 & & 1,936 & 111 \\
\hline 1979 & -328 & & -310 & -18 & -397 & & -377 & -21 \\
\hline 1980 & 343 & & 296 & 47 & 343 & & 296 & 47 \\
\hline 1981 & 887 & & 790 & 97 & 797 & & 709 & 87 \\
\hline 1982 & 1,941 & & 1,658 & 283 & 1,515 & & 1,293 & 221 \\
\hline 1983 & 144 & & 138 & 5 & 99 & & 95 & 4 \\
\hline 1984 & 1,025 & & 923 & 102 & 828 & & 759 & 70 \\
\hline 1985 & $-1,220$ & & -489 & -731 & -841 & & -370 & -472 \\
\hline 1986 & 1,086 & & 332 & 754 & 683 & & 218 & 464 \\
\hline 1987 & -938 & & -233 & -705 & -582 & & -162 & -420 \\
\hline 1988 & -141 & & -74 & -67 & -62 & & -22 & -40 \\
\hline 1989 & 816 & & 333 & 483 & 685 & & 409 & 275 \\
\hline 1990 & 1,287 & & 944 & 343 & 1,369 & & 1,180 & 189 \\
\hline 1991 & 1,969 & & 1,318 & 651 & 1,807 & & 1,465 & 342 \\
\hline 1992 & 396 & & 318 & 78 & 380 & & 340 & 41 \\
\hline 1993 & 374 & & 225 & 149 & 305 & & 227 & 78 \\
\hline 1994 & 243 & & 159 & 84 & 194 & & 150 & 44 \\
\hline 1995 & 178 & & 119 & 59 & 144 & & 113 & 31 \\
\hline 1996 & 344 & & 248 & 96 & 286 & & 235 & 51 \\
\hline
\end{tabular}

* These series were not used to estimate the stock of ships in maritime transport. Instead administrative records were used as described in Section 3. 
Table C.7: Gross Fixed Capital Formation at Current \& Constant Prices, Air Transport (Including Air France and Air Inter)

\begin{tabular}{|c|c|c|c|c|c|c|c|c|}
\hline & \multicolumn{4}{|c|}{$\begin{array}{l}\text { Gross fixed capital formation at current } \\
\text { prices (million French francs) }\end{array}$} & \multicolumn{4}{|c|}{$\begin{array}{c}\text { Gross fixed capital formation at constant } \\
\text { prices (million } 1980 \text { French francs) }\end{array}$} \\
\hline & TOTAL & $\begin{array}{c}\text { Non- } \\
\text { residentia } \\
1 \\
\text { structures }\end{array}$ & $\begin{array}{c}\text { Transport } \\
\text { equipment } \\
*\end{array}$ & $\begin{array}{c}\text { Other } \\
\text { machinery } \\
\& \\
\text { equipment }\end{array}$ & TOTAL & $\begin{array}{c}\text { Non- } \\
\text { residentia } \\
1 \\
\text { structures } \\
\end{array}$ & $\begin{array}{c}\text { Transport } \\
\text { equipment } \\
*\end{array}$ & $\begin{array}{c}\text { Other } \\
\text { machinery } \\
\& \\
\text { equipment }\end{array}$ \\
\hline 1962 & 370 & 148 & 185 & 37 & 1,162 & 611 & 443 & 109 \\
\hline 1963 & 371 & 148 & 185 & 37 & 1,114 & 570 & 440 & 105 \\
\hline 1964 & 266 & 106 & 133 & 27 & 779 & 386 & 319 & 74 \\
\hline 1965 & 280 & 112 & 140 & 28 & 803 & 395 & 332 & 76 \\
\hline 1966 & 380 & 152 & 190 & 38 & 1,070 & 524 & 445 & 101 \\
\hline 1967 & 428 & 171 & 214 & 43 & 1,173 & 569 & 494 & 110 \\
\hline 1968 & 780 & 312 & 390 & 78 & 2,101 & 985 & 902 & 214 \\
\hline 1969 & 870 & 348 & 435 & 87 & 2,265 & 1,052 & 982 & 231 \\
\hline 1970 & 773 & 572 & 184 & 17 & 2,062 & 1,621 & 401 & 40 \\
\hline 1971 & 496 & 187 & 286 & 23 & 1,137 & 498 & 586 & 54 \\
\hline 1972 & 764 & 576 & 174 & 14 & 1,782 & 1,437 & 315 & 29 \\
\hline 1973 & 1,210 & 615 & 541 & 54 & 2,674 & 1,403 & 1,143 & 128 \\
\hline 1974 & 1,498 & 557 & 856 & 84 & 2,935 & 1,097 & 1,656 & 182 \\
\hline 1975 & 1,466 & 562 & 841 & 63 & 2,623 & 975 & 1,521 & 128 \\
\hline 1976 & 2,090 & 249 & 1,716 & 126 & 3,217 & 383 & 2,618 & 215 \\
\hline 1977 & 1,981 & 395 & 1,633 & 398 & 3,041 & 542 & 1,963 & 536 \\
\hline 1978 & 1,664 & 407 & 1,663 & 291 & 2,759 & 512 & 1,894 & 353 \\
\hline 1979 & 2,376 & 109 & 2,060 & 244 & 2,641 & 124 & 2,246 & 271 \\
\hline 1980 & 3,413 & 507 & 3,315 & 340 & 4,163 & 507 & 3,315 & 340 \\
\hline 1981 & 4,977 & 595 & 4,214 & 570 & 4,854 & 540 & 3,794 & 520 \\
\hline 1982 & 4,218 & 480 & 3,534 & 541 & 3,580 & 390 & 2,747 & 442 \\
\hline 1983 & 3,627 & 527 & 3,173 & 466 & 2,877 & 399 & 2,128 & 350 \\
\hline 1984 & 2,427 & 661 & 2,490 & 287 & 2,338 & 466 & 1,674 & 199 \\
\hline 1985 & 3,164 & 473 & 3,019 & 344 & 2,433 & 320 & 1,882 & 231 \\
\hline 1986 & 4,612 & 286 & 4,018 & 505 & 2,426 & 188 & 1,903 & 335 \\
\hline 1987 & 6,788 & 1,568 & 3,787 & 1,913 & 3,815 & 1,002 & 1,593 & 1,219 \\
\hline 1988 & 8,220 & 1,927 & 7,854 & 1,156 & 5,085 & 1,191 & 3,169 & 725 \\
\hline 1989 & 9,187 & 1,918 & 8,920 & 1,086 & 5,725 & 1,157 & 3,904 & 663 \\
\hline 1990 & 9,175 & 1,910 & 8,950 & 984 & 5,784 & 1,130 & 4,061 & 593 \\
\hline 1991 & & 2,461 & 11,677 & 1,330 & 7,393 & 1,395 & 5,211 & 787 \\
\hline \multirow[t]{2}{*}{1992} & & 974 & 8,883 & 989 & 4,886 & 546 & 3,756 & 585 \\
\hline & 10,018 & & & & & & & \\
\hline \multirow[t]{2}{*}{1993} & & 1,408 & 10,683 & 889 & 5,597 & 777 & 4,302 & 519 \\
\hline & 11,436 & & & & & & & \\
\hline 1994 & 6,338 & 2,225 & 6,610 & 480 & 4,036 & 1,218 & 2,556 & 262 \\
\hline \multirow[t]{2}{*}{1995} & & 3,173 & 11,447 & 1,312 & 7,090 & 1,714 & 4,612 & 764 \\
\hline & 14,409 & & & & & & & \\
\hline 1996 & 11457 & 386 & 9,478 & 920 & 4,406 & 207 & 3,738 & 461 \\
\hline \multirow[t]{2}{*}{1997} & & 547 & 9,993 & 908 & 4,513 & 288 & 3,689 & 536 \\
\hline & 11,446 & & & & & & & \\
\hline
\end{tabular}

* These series were not used to estimate the stock of aircraft. Instead administrative records were used as described in Section 3. 
Table C.8: Gross Fixed Capital Formation at Current \& Constant Prices, Air France

\begin{tabular}{|c|c|c|c|c|c|c|c|c|}
\hline & \multicolumn{4}{|c|}{$\begin{array}{l}\text { Gross fixed capital formation at current } \\
\text { prices (million French francs) }\end{array}$} & \multicolumn{4}{|c|}{$\begin{array}{c}\text { Gross fixed capital formation at constant } \\
\text { prices (million } 1980 \text { French francs) }\end{array}$} \\
\hline & TOTAL & $\begin{array}{c}\text { Non- } \\
\text { residentia } \\
1 \\
\text { structures }\end{array}$ & $\begin{array}{c}\text { Transport } \\
\text { equipment } \\
*\end{array}$ & $\begin{array}{c}\text { Other } \\
\text { machinery } \\
\& \\
\text { equipment }\end{array}$ & TOTAL & $\begin{array}{c}\text { Non- } \\
\text { residentia } \\
1 \\
\text { structures }\end{array}$ & $\begin{array}{c}\text { Transport } \\
\text { equipment } \\
*\end{array}$ & $\begin{array}{c}\text { Other } \\
\text { machinery } \\
\& \\
\text { equipment }\end{array}$ \\
\hline 1970 & 547 & 100 & 8 & 655 & 1,786 & 1,549 & 219 & 18 \\
\hline 1971 & 158 & 219 & 16 & 393 & 906 & 420 & 448 & 38 \\
\hline 1972 & 548 & 120 & 9 & 677 & 1,604 & 1,368 & 218 & 18 \\
\hline 1973 & 504 & 129 & 10 & 643 & 1,447 & 1,150 & 273 & 23 \\
\hline 1974 & 317 & 666 & 50 & 1,033 & 2,023 & 624 & 1,290 & 109 \\
\hline 1975 & 346 & 719 & 54 & 1,119 & 2,012 & 600 & 1,302 & 110 \\
\hline 1976 & 135 & 1,257 & 95 & 1,487 & 2,292 & 208 & 1,921 & 162 \\
\hline 1977 & 151 & 1,070 & 104 & 1,325 & 1,633 & 207 & 1,286 & 140 \\
\hline 1978 & 50 & 825 & 160 & 1,035 & 1,198 & 63 & 940 & 195 \\
\hline 1979 & 52 & 1,411 & 120 & 1,583 & 1,732 & 59 & 1,539 & 134 \\
\hline 1980 & 89 & 2,005 & 133 & 2,227 & 2,227 & 89 & 2,005 & 133 \\
\hline 1981 & 169 & 2,220 & 163 & 2,552 & 2,300 & 153 & 1,999 & 148 \\
\hline 1982 & 169 & 2,120 & 156 & 2,445 & 1,912 & 137 & 1,648 & 127 \\
\hline 1983 & 99 & 1,600 & 117 & 1,816 & 1,236 & 75 & 1,073 & 88 \\
\hline 1984 & 95 & 1,350 & 97 & 1,542 & 1,042 & 67 & 907 & 68 \\
\hline 1985 & 86 & 2,119 & 153 & 2,358 & 1,481 & 58 & 1,321 & 102 \\
\hline 1986 & 137 & 2,865 & 209 & 3,211 & 1,585 & 90 & 1,357 & 138 \\
\hline 1987 & 779 & 693 & 51 & 1,523 & 823 & 498 & 292 & 33 \\
\hline 1988 & 373 & 3,763 & 278 & 4,414 & 1,925 & 231 & 1,520 & 174 \\
\hline 1989 & 318 & 3,215 & 236 & 3,769 & 1,745 & 192 & 1,408 & 145 \\
\hline 1990 & 305 & 3,085 & 228 & 3,618 & 1,718 & 180 & 1,400 & 138 \\
\hline 1991 & 545 & 5,532 & 408 & 6,485 & 3,020 & 309 & 2,470 & 241 \\
\hline 1992 & 496 & 4,567 & 335 & 5,398 & 2,407 & 278 & 1,931 & 198 \\
\hline 1993 & 500 & 3,290 & 241 & 4,031 & 1,741 & 276 & 1,325 & 140 \\
\hline 1994 & 390 & $-1,202$ & -87 & -899 & -299 & 213 & -468 & -44 \\
\hline 1995 & 376 & 1,856 & 137 & 2,369 & 1,030 & 203 & 748 & 79 \\
\hline 1996 & 413 & -588 & -43 & -218 & -33 & 221 & -232 & -22 \\
\hline 1997 & 319 & 2,835 & 207 & 3,361 & 1,337 & 168 & 1,047 & 122 \\
\hline
\end{tabular}


Table C.9: Gross Fixed Capital Formation at Current \& Constant Prices, Air Inter

\begin{tabular}{|c|c|c|c|c|c|c|c|c|}
\hline & \multicolumn{4}{|c|}{$\begin{array}{l}\text { Gross fixed capital formation at current } \\
\text { prices (million French francs) }\end{array}$} & \multicolumn{4}{|c|}{$\begin{array}{l}\text { Gross fixed capital formation at constant } \\
\text { prices (million } 1980 \text { French francs) }\end{array}$} \\
\hline & TOTAL & $\begin{array}{c}\text { Non- } \\
\text { residentia } \\
1 \\
\text { structures }\end{array}$ & $\begin{array}{c}\text { Transport } \\
\text { equipment } \\
*\end{array}$ & $\begin{array}{c}\text { Other } \\
\text { machinery } \\
\& \\
\text { equipment }\end{array}$ & TOTAL & $\begin{array}{c}\text { Non- } \\
\text { residentia } \\
1 \\
\text { structures }\end{array}$ & $\begin{array}{c}\text { Transport } \\
\text { equipment } \\
*\end{array}$ & $\begin{array}{c}\text { Other } \\
\text { machinery } \\
\& \\
\text { equipment }\end{array}$ \\
\hline 1965 & 3 & 2 & -1 & 2 & 10 & 8 & -2 & 4 \\
\hline 1966 & 75 & 31 & 42 & 2 & 212 & 105 & 102 & 4 \\
\hline 1967 & 171 & -5 & 174 & 2 & 404 & -17 & 415 & 6 \\
\hline 1968 & 7 & -15 & 20 & 2 & 7 & -47 & 48 & 6 \\
\hline 1969 & -4 & 1 & -7 & 2 & -8 & 2 & -16 & 6 \\
\hline 1970 & 9 & 5 & 4 & 0 & 23 & 14 & 8 & 1 \\
\hline 1971 & 27 & 15 & 11 & 1 & 65 & 40 & 23 & 2 \\
\hline 1972 & 29 & 17 & 11 & 1 & 64 & 42 & 20 & 2 \\
\hline 1973 & 22 & 9 & 12 & 1 & 48 & 21 & 25 & 2 \\
\hline 1974 & 256 & 191 & 60 & 5 & 500 & 376 & 114 & 9 \\
\hline 1975 & 248 & 209 & 36 & 3 & 431 & 362 & 64 & 5 \\
\hline 1976 & 173 & 81 & 86 & 6 & 264 & 125 & 128 & 11 \\
\hline 1977 & 241 & 91 & 113 & 37 & 310 & 125 & 136 & 49 \\
\hline 1978 & 357 & 12 & 328 & 17 & 408 & 15 & 373 & 20 \\
\hline 1979 & 26 & 6 & 4 & 16 & 28 & 7 & 4 & 17 \\
\hline 1980 & 386 & 9 & 355 & 22 & 386 & 9 & 355 & 22 \\
\hline 1981 & 211 & 13 & 179 & 19 & 192 & 12 & 161 & 19 \\
\hline 1982 & 176 & 13 & 148 & 15 & 139 & 11 & 115 & 13 \\
\hline 1983 & 282 & 8 & 249 & 25 & 191 & 6 & 167 & 18 \\
\hline 1984 & 530 & 10 & 471 & 49 & 357 & 7 & 317 & 33 \\
\hline 1985 & 352 & 10 & 310 & 32 & 222 & 7 & 193 & 22 \\
\hline 1986 & 102 & 33 & 62 & 7 & 57 & 22 & 29 & 6 \\
\hline 1987 & 247 & 113 & 120 & 14 & 130 & 72 & 50 & 8 \\
\hline 1988 & 1432 & 25 & 1260 & 147 & 614 & 15 & 507 & 92 \\
\hline 1989 & 1442 & 25 & 1270 & 147 & 658 & 15 & 555 & 88 \\
\hline 1990 & 1408 & 23 & 1239 & 146 & 662 & 14 & 562 & 86 \\
\hline 1991 & 1744 & 32 & 1531 & 181 & 807 & 18 & 682 & 107 \\
\hline 1992 & 435 & 29 & 364 & 42 & 196 & 16 & 154 & 26 \\
\hline 1993 & 813 & 29 & 701 & 83 & 348 & 16 & 282 & 50 \\
\hline 1994 & 1571 & 23 & 1383 & 165 & 653 & 13 & 538 & 102 \\
\hline 1995 & 803 & 22 & 698 & 83 & 345 & 12 & 281 & 52 \\
\hline 1996 & -357 & 24 & -340 & -41 & -148 & 13 & -134 & -27 \\
\hline 1997 & 0 & 19 & -18 & -1 & 2 & 10 & -7 & -1 \\
\hline
\end{tabular}

* These series were not used to estimate the stock of aircraft. Instead administrative records were used as described in Section 3. 
Table C.10: GFCF at Current \& Constant Prices, Transport Services

\begin{tabular}{|c|c|c|c|c|c|c|c|c|}
\hline & \multicolumn{4}{|c|}{$\begin{array}{c}\text { Gross fixed capital formation at current } \\
\text { prices (million French francs) }\end{array}$} & \multicolumn{4}{|c|}{$\begin{array}{l}\text { Gross fixed capital formation at constant } \\
\text { prices (million } 1980 \text { French francs) }\end{array}$} \\
\hline & TOTAL & $\begin{array}{c}\text { Non- } \\
\text { residentia } \\
1 \\
\text { structures } \\
\end{array}$ & $\begin{array}{l}\text { Transport } \\
\text { equipment }\end{array}$ & $\begin{array}{c}\text { Other } \\
\text { machinery } \\
\& \\
\text { equipment } \\
\end{array}$ & TOTAL & $\begin{array}{c}\text { Non- } \\
\text { residentia } \\
1 \\
\text { structures }\end{array}$ & $\begin{array}{c}\text { Transport } \\
\text { equipment }\end{array}$ & $\begin{array}{c}\text { Other } \\
\text { machinery } \\
\& \\
\text { equipment }\end{array}$ \\
\hline 1950 & & 555 & & & & 5,035 & & \\
\hline 1951 & & 364 & & & & 2,745 & & \\
\hline 1952 & & 379 & & & & 2,285 & & \\
\hline 1953 & & 403 & & & & 2,457 & & \\
\hline 1954 & & 447 & & & & 2,723 & & \\
\hline 1955 & & 474 & & & & 2,811 & & \\
\hline 1956 & & 458 & & & & 2,609 & & \\
\hline 1957 & 448 & 431 & 4 & 13 & 2,329 & 2,261 & 16 & 52 \\
\hline 1958 & 508 & 488 & 5 & 15 & 2,438 & 2,372 & 15 & 51 \\
\hline 1959 & 726 & 698 & 7 & 21 & 3,353 & 3,264 & 20 & 69 \\
\hline 1960 & 889 & 855 & 9 & 26 & 4,063 & 3,958 & 25 & 81 \\
\hline 1961 & 924 & 888 & 9 & 27 & 3,973 & 3,866 & 24 & 82 \\
\hline 1962 & 852 & 819 & 8 & 25 & 3,479 & 3,384 & 22 & 74 \\
\hline 1963 & 944 & 908 & 9 & 27 & 3,592 & 3,489 & 24 & 79 \\
\hline 1964 & 1,031 & 991 & 10 & 30 & 3,714 & 3,604 & 26 & 84 \\
\hline 1965 & 1,240 & 1,192 & 12 & 36 & 4,346 & 4,216 & 31 & 99 \\
\hline 1966 & 1,626 & 1,563 & 16 & 47 & 5,555 & 5,388 & 40 & 128 \\
\hline 1967 & 1,985 & 1,909 & 19 & 57 & 6,549 & 6,350 & 48 & 151 \\
\hline 1968 & 2,207 & 2,122 & 21 & 64 & 6,936 & 6,700 & 57 & 179 \\
\hline 1969 & 2,298 & 2,210 & 22 & 66 & 6,922 & 6,684 & 57 & 181 \\
\hline 1970 & 2,639 & 2,537 & 25 & 76 & 7,438 & 7,185 & 63 & 190 \\
\hline 1971 & 3,600 & 3,461 & 35 & 104 & 9,525 & 9,203 & 80 & 242 \\
\hline 1972 & 3,915 & 3,765 & 38 & 113 & 9,726 & 9,394 & 83 & 250 \\
\hline 1973 & 4,820 & 4,646 & 53 & 121 & & 10,600 & 115 & 266 \\
\hline 1974 & 5,981 & 5,746 & 81 & 155 & $\begin{array}{l}10,981 \\
11,762\end{array}$ & 11,308 & 154 & 300 \\
\hline 1975 & 7,736 & 7,489 & 70 & 177 & 13,406 & 12,984 & 119 & 303 \\
\hline 1976 & 7,163 & 6,863 & 74 & 226 & 11,032 & 10,579 & 111 & 342 \\
\hline 1977 & 7,671 & 7,363 & 96 & 212 & 10,516 & 10,096 & 131 & 289 \\
\hline 1978 & 6,665 & 6,407 & 75 & 183 & 8,401 & 8,080 & 94 & 227 \\
\hline 1979 & 7,091 & 6,809 & 100 & 182 & 8,093 & 7,774 & 112 & 207 \\
\hline 1980 & 5,880 & 5,588 & 97 & 195 & 5,880 & 5,588 & 97 & 195 \\
\hline 1981 & 8,878 & 8,473 & 149 & 256 & 8,033 & 7,668 & 135 & 229 \\
\hline 1982 & 8,407 & 8,091 & 116 & 200 & 6,832 & 6,580 & 95 & 156 \\
\hline 1983 & 7,242 & 6,957 & 107 & 179 & 5,465 & 5,257 & 80 & 129 \\
\hline 1984 & 7,335 & 7,050 & 94 & 190 & 5,202 & 5,004 & 68 & 129 \\
\hline 1985 & 7,344 & 6,941 & 172 & 231 & 4,960 & 4,691 & 119 & 149 \\
\hline 1986 & 8,021 & 7,600 & 156 & 266 & 5,278 & 5,014 & 100 & 164 \\
\hline 1987 & 9,303 & 8,721 & 192 & 390 & 5,921 & 5,570 & 118 & 232 \\
\hline 1988 & 11,031 & 10,370 & 182 & 479 & 6,810 & 6,417 & 109 & 283 \\
\hline 1989 & 13,305 & 12,626 & 233 & 446 & 8,003 & 7,616 & 133 & 254 \\
\hline 1990 & 14,809 & 14,124 & 239 & 445 & 8,701 & 8,323 & 132 & 246 \\
\hline
\end{tabular}


Capital Stock and Productivity in French Transport : An International Comparison

\begin{tabular}{|c|c|c|c|c|c|c|c|c|}
\hline 1991 & 16061 & 16,202 & 280 & 479 & 9,580 & 9,179 & 150 & 252 \\
\hline 1992 & 18.497 & 17,751 & 265 & 481 & 10314 & 9,926 & 137 & 251 \\
\hline 1993 & 19,633 & 18,822 & 288 & 523 & 10,807 & 10,384 & 149 & 273 \\
\hline 1994 & 19,763 & 18,693 & 507 & 564 & 10,776 & 10,221 & 255 & 299 \\
\hline 1995 & 21,554 & 20,747 & 259 & 549 & 11,625 & 11,209 & 125 & 291 \\
\hline 1996 & 24,388 & 23,761 & 244 & 383 & 12,994 & 12,674 & 118 & 202 \\
\hline
\end{tabular}





\section{ANNEX D - Gross AND NeT CAPITAL STOCKS}

Table D.1: Gross and Net Capital Stocks, Railways (SNCF), 1970-97 (million 1980 French francs)

\begin{tabular}{|c|c|c|c|c|c|c|c|c|}
\hline & \multicolumn{2}{|c|}{$\begin{array}{c}\text { Non-residential } \\
\text { structures }\end{array}$} & \multicolumn{2}{|c|}{$\begin{array}{l}\text { Transport } \\
\text { equipment }\end{array}$} & \multicolumn{2}{|c|}{$\begin{array}{c}\text { Other machinery } \\
\text { \& equipment } \\
\end{array}$} & \multicolumn{2}{|c|}{ All assets } \\
\hline & $\begin{array}{l}\text { Gross } \\
\text { stock }\end{array}$ & $\begin{array}{l}\text { Net } \\
\text { stock }\end{array}$ & $\begin{array}{l}\text { Gross } \\
\text { stock }\end{array}$ & $\begin{array}{l}\text { Net } \\
\text { stock }\end{array}$ & $\begin{array}{l}\text { Gross } \\
\text { stock }\end{array}$ & $\begin{array}{c}\text { Net } \\
\text { stock }\end{array}$ & $\begin{array}{l}\text { Gross } \\
\text { stock }\end{array}$ & $\begin{array}{l}\text { Net } \\
\text { stock }\end{array}$ \\
\hline 1970 & 104656 & 85180 & 71617 & 47894 & 19683 & 11260 & 195957 & 144334 \\
\hline 1971 & 109421 & 88246 & 73502 & 48275 & 19525 & 10981 & 202448 & 147501 \\
\hline 1972 & 113024 & 90105 & 75336 & 48793 & 19045 & 10560 & 207405 & 149458 \\
\hline 1973 & 116684 & 92003 & 77291 & 49507 & 19490 & 10865 & 213464 & 152375 \\
\hline 1974 & 120486 & 94024 & 79774 & 50739 & 19684 & 10838 & 219944 & 155601 \\
\hline 1975 & 124525 & 96263 & 82461 & 52244 & 20297 & 11329 & 227283 & 159836 \\
\hline 1976 & 128236 & 98146 & 85007 & 53737 & 20808 & 11806 & 234051 & 163690 \\
\hline 1977 & 132446 & 100511 & 87680 & 55532 & 20489 & 11574 & 240616 & 167617 \\
\hline 1978 & 137459 & 103650 & 89831 & 57001 & 20103 & 11351 & 247393 & 172002 \\
\hline 1979 & 142569 & 106814 & 91348 & 57898 & 19748 & 11134 & 253666 & 175846 \\
\hline 1980 & 147819 & 110045 & 92759 & 58677 & 19549 & 11052 & 260127 & 179774 \\
\hline 1981 & 153140 & 113273 & 94500 & 59957 & 19402 & 11104 & 267042 & 184334 \\
\hline 1982 & 158127 & 116093 & 95949 & 60853 & 19163 & 11074 & 273239 & 188021 \\
\hline 1983 & 162969 & 118704 & 97387 & 61730 & 19031 & 11051 & 279387 & 191485 \\
\hline 1984 & 167508 & 120952 & 98127 & 62010 & 18946 & 10957 & 284581 & 193919 \\
\hline 1985 & 171604 & 122705 & 98401 & 62036 & 18753 & 10785 & 288758 & 195527 \\
\hline 1986 & 176496 & 125215 & 98917 & 62467 & 18689 & 10758 & 294102 & 198440 \\
\hline 1987 & 181805 & 128084 & 98769 & 62361 & 18424 & 10559 & 298998 & 201004 \\
\hline 1988 & 186856 & 130928 & 99226 & 62996 & 18349 & 10606 & 304431 & 204530 \\
\hline 1989 & 191569 & 133535 & 99625 & 63636 & 18234 & 10590 & 309427 & 207762 \\
\hline 1990 & 197480 & 137467 & 101000 & 65203 & 18398 & 10870 & 316878 & 213540 \\
\hline 1991 & 204150 & 142328 & 103009 & 67282 & 18765 & 11354 & 325924 & 220965 \\
\hline 1992 & 209717 & 146253 & 106840 & 70891 & 19703 & 12310 & 336260 & 229454 \\
\hline 1993 & 215004 & 150041 & 108037 & 71689 & 19885 & 12416 & 342927 & 234146 \\
\hline 1994 & 218419 & 152134 & 108605 & 71847 & 19995 & 12366 & 347019 & 236348 \\
\hline 1995 & 221297 & 153907 & 108893 & 71766 & 20070 & 12212 & 350260 & 237885 \\
\hline 1996 & 224332 & 156081 & 110182 & 72782 & 20507 & 12446 & 355021 & 241308 \\
\hline 1997 & 225756 & 156838 & 112578 & 74935 & 21233 & 12939 & 359567 & 244712 \\
\hline
\end{tabular}


Table D.2: Gross and Net Capital Stocks, Road Freight Transport, 1970-97 (million 1980 French francs)

\begin{tabular}{|c|c|c|c|c|c|c|c|c|}
\hline & \multicolumn{2}{|c|}{$\begin{array}{c}\text { Non-residential } \\
\text { structures }\end{array}$} & \multicolumn{2}{|c|}{$\begin{array}{l}\text { Transport } \\
\text { equipment }\end{array}$} & \multicolumn{2}{|c|}{$\begin{array}{l}\text { Other machinery } \\
\text { \& equipment }\end{array}$} & \multicolumn{2}{|c|}{ All assets } \\
\hline & $\begin{array}{l}\text { Gross } \\
\text { stock }\end{array}$ & $\begin{array}{l}\text { Net } \\
\text { stock }\end{array}$ & $\begin{array}{l}\text { Gross } \\
\text { stock }\end{array}$ & $\begin{array}{c}\text { Net } \\
\text { stock }\end{array}$ & $\begin{array}{l}\text { Gross } \\
\text { stock }\end{array}$ & $\begin{array}{c}\text { Net } \\
\text { stock }\end{array}$ & $\begin{array}{l}\text { Gross } \\
\text { stock }\end{array}$ & $\begin{array}{r}\text { Net } \\
\text { stock }\end{array}$ \\
\hline 1970 & 4636 & 3670 & 11994 & 6090 & 3681 & 2334 & 20312 & 12094 \\
\hline 1971 & 4830 & 3839 & 12993 & 6613 & 3951 & 2504 & 21774 & 12956 \\
\hline 1972 & 5060 & 4048 & 14245 & 7331 & 4293 & 2735 & 23598 & 14114 \\
\hline 1973 & 5273 & 4241 & 15599 & 8054 & 5202 & 3515 & 26074 & 15810 \\
\hline 1974 & 5432 & 4381 & 16690 & 8453 & 5887 & 3997 & 28009 & 16831 \\
\hline 1975 & 5455 & 4388 & 17070 & 8159 & 6338 & 4213 & 28863 & 16761 \\
\hline 1976 & 5478 & 4403 & 18912 & 9443 & 6261 & 3893 & 30651 & 17740 \\
\hline 1977 & 5524 & 4451 & 20772 & 10584 & 6184 & 3629 & 32481 & 18664 \\
\hline 1978 & 5525 & 4462 & 22507 & 11468 & 6093 & 3398 & 34125 & 19328 \\
\hline 1979 & 5544 & 4490 & 23577 & 11612 & 5912 & 3124 & 35034 & 19226 \\
\hline 1980 & 5610 & 4564 & 25036 & 12189 & 5757 & 2926 & 36403 & 19679 \\
\hline 1981 & 5639 & 4597 & 25882 & 12156 & 5529 & 2706 & 37051 & 19459 \\
\hline 1982 & 5684 & 4644 & 27137 & 12652 & 5309 & 2549 & 38129 & 19844 \\
\hline 1983 & 5724 & 4681 & 28032 & 12862 & 5061 & 2427 & 38818 & 19970 \\
\hline 1984 & 5755 & 4708 & 28878 & 13132 & 4661 & 2315 & 39294 & 20154 \\
\hline 1985 & 5740 & 4687 & 29361 & 13083 & 4143 & 2200 & 39245 & 19970 \\
\hline 1986 & 5782 & 4726 & 30375 & 13519 & 3643 & 2174 & 39800 & 20420 \\
\hline 1987 & 5886 & 4829 & 31798 & 14514 & 3244 & 2200 & 40929 & 21542 \\
\hline 1988 & 6027 & 4968 & 33402 & 15700 & 2936 & 2248 & 42365 & 22915 \\
\hline 1989 & 6264 & 5202 & 36267 & 18087 & 2901 & 2383 & 45432 & 25672 \\
\hline 1990 & 6402 & 5333 & 37768 & 18767 & 2870 & 2351 & 47040 & 26451 \\
\hline 1991 & 6473 & 5395 & 38580 & 18924 & 2841 & 2222 & 47895 & 26542 \\
\hline 1992 & 6554 & 5467 & 41117 & 20653 & 3028 & 2313 & 50698 & 28432 \\
\hline 1993 & 6578 & 5481 & 43037 & 21433 & 3140 & 2311 & 52755 & 29226 \\
\hline 1994 & 6697 & 5594 & 44945 & 22003 & 3266 & 2319 & 54909 & 29916 \\
\hline 1995 & 6951 & 5844 & 47947 & 23643 & 3566 & 2508 & 58464 & 31995 \\
\hline 1996 & 7273 & 6160 & 50216 & 24194 & 3688 & 2494 & 61177 & 32848 \\
\hline 1997 & 7132 & 6012 & 47750 & 20042 & 3500 & 2193 & 58382 & 28247 \\
\hline
\end{tabular}


Table D.3: Gross and Net Capital Stocks, Urban Passenger Transport in Paris \& Surroundings (RATP), 1970-97

(million 1980 French francs)

\begin{tabular}{|c|c|c|c|c|c|c|c|c|}
\hline & \multicolumn{2}{|c|}{$\begin{array}{c}\text { Non-residential } \\
\text { structures }\end{array}$} & \multicolumn{2}{|c|}{$\begin{array}{l}\text { Transport } \\
\text { equipment }\end{array}$} & \multicolumn{2}{|c|}{$\begin{array}{c}\text { Other machinery } \\
\text { \& equipment } \\
\end{array}$} & \multicolumn{2}{|c|}{ All assets } \\
\hline & $\begin{array}{l}\text { Gross } \\
\text { stock }\end{array}$ & $\begin{array}{c}\text { Net } \\
\text { stock }\end{array}$ & $\begin{array}{l}\text { Gross } \\
\text { stock }\end{array}$ & $\begin{array}{c}\text { Net } \\
\text { stock }\end{array}$ & $\begin{array}{l}\text { Gross } \\
\text { stock }\end{array}$ & $\begin{array}{c}\text { Net } \\
\text { stock }\end{array}$ & $\begin{array}{l}\text { Gross } \\
\text { stock }\end{array}$ & $\begin{array}{r}\text { Net } \\
\text { stock }\end{array}$ \\
\hline 1970 & 13264 & 11689 & 3881 & 2463 & 2831 & 1862 & 19975 & 16013 \\
\hline 1971 & 14803 & 12955 & 3953 & 2438 & 2922 & 1754 & 21678 & 17147 \\
\hline 1972 & 15991 & 13842 & 4084 & 2470 & 3074 & 1738 & 23148 & 18050 \\
\hline 1973 & 17204 & 14733 & 4333 & 2608 & 3198 & 1724 & 24735 & 19065 \\
\hline 1974 & 18468 & 15654 & 4610 & 2741 & 3306 & 1737 & 26384 & 20133 \\
\hline 1975 & 19812 & 16635 & 4953 & 2930 & 3425 & 1788 & 28190 & 21353 \\
\hline 1976 & 21062 & 17498 & 5334 & 3118 & 3507 & 1825 & 29904 & 22441 \\
\hline 1977 & 22473 & 18503 & 5751 & 3335 & 3434 & 1736 & 31658 & 23574 \\
\hline 1978 & 24139 & 19738 & 6109 & 3499 & 3328 & 1657 & 33576 & 24894 \\
\hline 1979 & 25834 & 20974 & 6343 & 3583 & 3160 & 1584 & 35337 & 26142 \\
\hline 1980 & 27573 & 22224 & 6495 & 3650 & 2922 & 1534 & 36989 & 27408 \\
\hline 1981 & 29333 & 23466 & 6642 & 3776 & 2710 & 1505 & 38685 & 28747 \\
\hline 1982 & 30990 & 24576 & 6755 & 3848 & 2519 & 1471 & 40264 & 29895 \\
\hline 1983 & 32590 & 25615 & 6849 & 3916 & 2354 & 1441 & 41793 & 30972 \\
\hline 1984 & 34078 & 26535 & 6878 & 3909 & 2244 & 1406 & 43199 & 31850 \\
\hline 1985 & 35418 & 27298 & 6884 & 3873 & 2197 & 1364 & 44498 & 32535 \\
\hline 1986 & 36965 & 28287 & 6953 & 3891 & 2141 & 1343 & 46059 & 33521 \\
\hline 1987 & 38616 & 29382 & 6965 & 3844 & 2037 & 1303 & 47619 & 34528 \\
\hline 1988 & 40267 & 30463 & 7070 & 3892 & 1973 & 1295 & 49311 & 35650 \\
\hline 1989 & 41863 & 31465 & 7129 & 3940 & 1916 & 1281 & 50908 & 36686 \\
\hline 1990 & 43869 & 32870 & 7265 & 4100 & 1913 & 1305 & 53047 & 38275 \\
\hline 1991 & 46182 & 34555 & 7449 & 4315 & 1963 & 1354 & 55594 & 40225 \\
\hline 1992 & 48231 & 35946 & 7827 & 4708 & 2096 & 1462 & 58154 & 42116 \\
\hline 1993 & 50249 & 37290 & 7868 & 4734 & 2136 & 1466 & 60252 & 43490 \\
\hline 1994 & 51746 & 38107 & 7835 & 4684 & 2155 & 1452 & 61735 & 44243 \\
\hline 1995 & 53134 & 38820 & 7775 & 4611 & 2158 & 1427 & 63068 & 44858 \\
\hline 1996 & 54629 & 39653 & 7870 & 4681 & 2209 & 1449 & 64707 & 45783 \\
\hline 1997 & 55656 & 40045 & 8130 & 4889 & 2298 & 1504 & 66084 & 46438 \\
\hline
\end{tabular}


Table D.4: Gross and Net Capital Stocks, Other Urban and Interurban Passenger Transport, 1970-97 (million 1980 French francs)

\begin{tabular}{|c|c|c|c|c|c|c|c|c|}
\hline & \multicolumn{2}{|c|}{$\begin{array}{l}\text { Non-residential } \\
\text { structures }\end{array}$} & \multicolumn{2}{|c|}{$\begin{array}{l}\text { Transport } \\
\text { equipment }\end{array}$} & \multicolumn{2}{|c|}{$\begin{array}{c}\text { Other machinery } \\
\text { \& equipment }\end{array}$} & \multicolumn{2}{|c|}{ All assets } \\
\hline & $\begin{array}{l}\text { Gross } \\
\text { stock }\end{array}$ & $\begin{array}{c}\text { Net } \\
\text { stock }\end{array}$ & $\begin{array}{l}\text { Gross } \\
\text { stock }\end{array}$ & $\begin{array}{c}\text { Net } \\
\text { stock }\end{array}$ & $\begin{array}{l}\text { Gross } \\
\text { stock }\end{array}$ & $\begin{array}{c}\text { Net } \\
\text { stock }\end{array}$ & $\begin{array}{l}\text { Gross } \\
\text { stock }\end{array}$ & $\begin{array}{r}\text { Net } \\
\text { stock }\end{array}$ \\
\hline 1970 & 15989 & 12704 & 6623 & 3902 & 1304 & 813 & 23917 & 17419 \\
\hline 1971 & 16851 & 13566 & 7625 & 4729 & 1487 & 968 & 25963 & 19263 \\
\hline 1972 & 18513 & 15229 & 9493 & 6381 & 1851 & 1289 & 29856 & 22899 \\
\hline 1973 & 19261 & 15960 & 11570 & 8070 & 2221 & 1581 & 33052 & 25611 \\
\hline 1974 & 19664 & 16351 & 12249 & 8188 & 2288 & 1540 & 34200 & 26079 \\
\hline 1975 & 20392 & 17080 & 13183 & 8568 & 2389 & 1543 & 35964 & 27191 \\
\hline 1976 & 21303 & 18002 & 14812 & 9618 & 2396 & 1455 & 38511 & 29075 \\
\hline 1977 & 23291 & 20013 & 17998 & 12129 & 2539 & 1518 & 43828 & 33660 \\
\hline 1978 & 23621 & 20352 & 19091 & 12287 & 2542 & 1436 & 45254 & 34074 \\
\hline 1979 & 24967 & 21691 & 20410 & 12675 & 2517 & 1342 & 47894 & 35709 \\
\hline 1980 & 25542 & 22218 & 21297 & 12625 & 2467 & 1243 & 49306 & 36086 \\
\hline 1981 & 26055 & 22660 & 21962 & 12394 & 2391 & 1137 & 50408 & 36191 \\
\hline 1982 & 26878 & 23393 & 22133 & 11723 & 2290 & 1050 & 51300 & 36166 \\
\hline 1983 & 27596 & 23994 & 22355 & 11299 & 2167 & 1017 & 52119 & 36309 \\
\hline 1984 & 28117 & 24377 & 22157 & 10747 & 2065 & 1073 & 52339 & 36196 \\
\hline 1985 & 29162 & 25267 & 22071 & 10643 & 2104 & 1266 & 53337 & 37176 \\
\hline 1986 & 29651 & 25578 & 21816 & 10453 & 2092 & 1397 & 53559 & 37428 \\
\hline 1987 & 30195 & 25935 & 21426 & 10247 & 2084 & 1484 & 53704 & 37666 \\
\hline 1988 & 30544 & 26092 & 20839 & 10060 & 2175 & 1621 & 53558 & 37773 \\
\hline 1989 & 30706 & 26057 & 19803 & 9864 & 2377 & 1782 & 52885 & 37703 \\
\hline 1990 & 30857 & 26018 & 18697 & 9655 & 2631 & 1962 & 52185 & 37635 \\
\hline 1991 & 31057 & 26032 & 17692 & 9513 & 2922 & 2131 & 51671 & 37676 \\
\hline 1992 & 31933 & 26729 & 16883 & 9433 & 3357 & 2413 & 52173 & 38575 \\
\hline 1993 & 32162 & 26763 & 16299 & 9611 & 3724 & 2554 & 52185 & 38929 \\
\hline 1994 & 32496 & 26900 & 15802 & 9773 & 4158 & 2744 & 52456 & 39417 \\
\hline 1995 & 32672 & 26871 & 15240 & 9692 & 4599 & 2936 & 52511 & 39500 \\
\hline 1996 & 33206 & 27196 & 15184 & 9716 & 4910 & 3027 & 53300 & 39939 \\
\hline 1997 & 32773 & 26551 & 14079 & 8627 & 4722 & 2656 & 51574 & 37834 \\
\hline
\end{tabular}


Table D.5: Gross and Net Capital Stocks, Inland Water Transport, 1970-97 (million 1980 French francs)

\begin{tabular}{|c|c|c|c|c|c|c|c|c|}
\hline & \multicolumn{2}{|c|}{$\begin{array}{c}\text { Non-residential } \\
\text { structures }\end{array}$} & \multicolumn{2}{|c|}{$\begin{array}{l}\text { Transport } \\
\text { equipment }\end{array}$} & \multicolumn{2}{|c|}{$\begin{array}{c}\text { Other machinery } \\
\text { \& equipment }\end{array}$} & \multicolumn{2}{|c|}{ All assets } \\
\hline & $\begin{array}{l}\text { Gross } \\
\text { stock }\end{array}$ & $\begin{array}{l}\text { Net } \\
\text { stock }\end{array}$ & $\begin{array}{l}\text { Gross } \\
\text { stock }\end{array}$ & $\begin{array}{c}\text { Net } \\
\text { stock }\end{array}$ & $\begin{array}{l}\text { Gross } \\
\text { stock }\end{array}$ & $\begin{array}{l}\text { Net } \\
\text { stock }\end{array}$ & $\begin{array}{l}\text { Gross } \\
\text { stock }\end{array}$ & $\begin{array}{l}\text { Net } \\
\text { stock }\end{array}$ \\
\hline 1970 & 866 & 687 & 2736 & 1671 & 492 & 262 & 4093 & 2620 \\
\hline 1971 & 853 & 680 & 2766 & 1620 & 472 & 240 & 4091 & 2540 \\
\hline 1972 & 837 & 669 & 2767 & 1550 & 445 & 215 & 4050 & 2434 \\
\hline 1973 & 817 & 656 & 2749 & 1473 & 416 & 190 & 3982 & 2319 \\
\hline 1974 & 801 & 641 & 2717 & 1395 & 380 & 163 & 3898 & 2199 \\
\hline 1975 & 778 & 631 & 2680 & 1324 & 350 & 150 & 3807 & 2105 \\
\hline 1976 & 754 & 616 & 2647 & 1271 & 312 & 130 & 3713 & 2016 \\
\hline 1977 & 728 & 603 & 2598 & 1214 & 276 & 114 & 3601 & 1931 \\
\hline 1978 & 701 & 590 & 2531 & 1154 & 241 & 102 & 3473 & 1847 \\
\hline 1979 & 674 & 579 & 2458 & 1097 & 207 & 92 & 3339 & 1768 \\
\hline 1980 & 651 & 567 & 2383 & 1046 & 173 & 84 & 3206 & 1697 \\
\hline 1981 & 626 & 559 & 2325 & 1024 & 145 & 82 & 3096 & 1665 \\
\hline 1982 & 614 & 550 & 2251 & 990 & 118 & 78 & 2983 & 1617 \\
\hline 1983 & 591 & 551 & 2196 & 981 & 119 & 95 & 2906 & 1627 \\
\hline 1984 & 564 & 542 & 2148 & 983 & 106 & 90 & 2818 & 1615 \\
\hline 1985 & 538 & 529 & 2001 & 891 & 92 & 75 & 2632 & 1495 \\
\hline 1986 & 517 & 517 & 1882 & 839 & 86 & 66 & 2486 & 1422 \\
\hline 1987 & 490 & 510 & 1841 & 873 & 87 & 64 & 2418 & 1447 \\
\hline 1988 & 470 & 497 & 1708 & 814 & 83 & 54 & 2260 & 1366 \\
\hline 1989 & 451 & 493 & 1674 & 861 & 81 & 49 & 2206 & 1403 \\
\hline 1990 & 426 & 489 & 1618 & 885 & 85 & 50 & 2129 & 1424 \\
\hline 1991 & 405 & 480 & 1593 & 940 & 91 & 52 & 2088 & 1473 \\
\hline 1992 & 399 & 474 & 1620 & 1038 & 130 & 90 & 2149 & 1602 \\
\hline 1993 & 385 & 485 & 1560 & 1039 & 160 & 113 & 2105 & 1637 \\
\hline 1994 & 363 & 486 & 1513 & 1044 & 183 & 131 & 2059 & 1661 \\
\hline 1995 & 342 & 479 & 1469 & 1044 & 223 & 164 & 2034 & 1687 \\
\hline 1996 & 316 & 471 & 1404 & 1010 & 271 & 199 & 1992 & 1680 \\
\hline 1997 & 291 & 460 & 1318 & 946 & 262 & 170 & 1871 & 1576 \\
\hline
\end{tabular}


Table D.6: Gross and Net Capital Stocks, Maritime Transport, 1970-97 (million 1980 French francs)

\begin{tabular}{|c|c|c|c|c|c|c|c|c|}
\hline & \multicolumn{2}{|c|}{$\begin{array}{c}\text { Non-residential } \\
\text { structures }\end{array}$} & \multicolumn{2}{|c|}{$\begin{array}{l}\text { Transport } \\
\text { equipment }\end{array}$} & \multicolumn{2}{|c|}{$\begin{array}{c}\text { Other machinery } \\
\text { \& equipment } \\
\end{array}$} & \multicolumn{2}{|c|}{ All assets } \\
\hline & $\begin{array}{l}\text { Gross } \\
\text { stock }\end{array}$ & $\begin{array}{c}\text { Net } \\
\text { stock }\end{array}$ & $\begin{array}{l}\text { Gross } \\
\text { stock }\end{array}$ & $\begin{array}{c}\text { Net } \\
\text { stock }\end{array}$ & $\begin{array}{l}\text { Gross } \\
\text { stock }\end{array}$ & $\begin{array}{c}\text { Net } \\
\text { stock }\end{array}$ & $\begin{array}{l}\text { Gross } \\
\text { stock }\end{array}$ & $\begin{array}{r}\text { Net } \\
\text { stock }\end{array}$ \\
\hline 1970 & 0 & 0 & 20828 & 13648 & 427 & 234 & 21255 & 13881 \\
\hline 1971 & 0 & 0 & 23126 & 15651 & 510 & 255 & 23637 & 15906 \\
\hline 1972 & 0 & 0 & 23547 & 16106 & 534 & 320 & 24081 & 16426 \\
\hline 1973 & 0 & 0 & 25137 & 17642 & 616 & 321 & 25754 & 17963 \\
\hline 1974 & 0 & 0 & 30646 & 22515 & 705 & 390 & 31352 & 22905 \\
\hline 1975 & 0 & 0 & 33939 & 24893 & 796 & 454 & 34735 & 25347 \\
\hline 1976 & 0 & 0 & 35520 & 26212 & 844 & 510 & 36364 & 26721 \\
\hline 1977 & 1 & 0 & 37523 & 27271 & 887 & 515 & 38410 & 27786 \\
\hline 1978 & 1 & 1 & 36578 & 25918 & 968 & 515 & 37546 & 26434 \\
\hline 1979 & 1 & 1 & 35111 & 24373 & 914 & 552 & 36025 & 24926 \\
\hline 1980 & 1 & 1 & 34913 & 22717 & 926 & 452 & 35840 & 23170 \\
\hline 1981 & 2 & 1 & 32879 & 19859 & 972 & 435 & 33853 & 20295 \\
\hline 1982 & 2 & 2 & 33228 & 18902 & 1139 & 459 & 34369 & 19363 \\
\hline 1983 & 2 & 2 & 31251 & 16358 & 1087 & 614 & 32340 & 16974 \\
\hline 1984 & 2 & 2 & 28817 & 13980 & 1085 & 530 & 29903 & 14512 \\
\hline 1985 & 2 & 2 & 26136 & 11931 & 525 & 523 & 26664 & 12456 \\
\hline 1986 & 3 & 2 & 24648 & 10704 & 888 & -23 & 25539 & 10683 \\
\hline 1987 & 3 & 2 & 22149 & 9301 & 372 & 444 & 22524 & 9747 \\
\hline 1988 & 3 & 2 & 20911 & 8054 & 230 & -40 & 21145 & 8016 \\
\hline 1989 & 3 & 2 & 19876 & 6911 & 405 & -74 & 20284 & 6839 \\
\hline 1990 & 3 & 2 & 18234 & 5973 & 521 & 212 & 18759 & 6187 \\
\hline 1991 & 3 & 2 & 17884 & 5531 & 805 & 371 & 18692 & 5904 \\
\hline 1992 & 3 & 2 & 18405 & 5925 & 786 & 659 & 19193 & 6586 \\
\hline 1993 & 3 & 2 & 17652 & 5263 & 775 & 605 & 18430 & 5870 \\
\hline 1994 & 3 & 2 & 16963 & 4765 & 752 & 596 & 17717 & 5363 \\
\hline 1995 & 3 & 2 & 16968 & 5018 & 697 & 555 & 17668 & 5575 \\
\hline 1996 & 3 & 2 & 17934 & 5617 & 766 & 507 & 18703 & 6126 \\
\hline 1997 & 3 & 2 & 18312 & 5916 & 709 & 485 & 19023 & 6403 \\
\hline
\end{tabular}


Table D.7: Gross and Net Capital Stocks, Air Transport, 1970-97 (million 1980 French francs)

\begin{tabular}{|c|c|c|c|c|c|c|c|c|}
\hline & \multicolumn{2}{|c|}{$\begin{array}{c}\text { Non-residential } \\
\text { structures }\end{array}$} & \multicolumn{2}{|c|}{$\begin{array}{l}\text { Transport } \\
\text { equipment }\end{array}$} & \multicolumn{2}{|c|}{$\begin{array}{l}\text { Other machinery } \\
\text { \& equipment }\end{array}$} & \multicolumn{2}{|c|}{ All assets } \\
\hline & $\begin{array}{l}\text { Gross } \\
\text { stock }\end{array}$ & $\begin{array}{l}\text { Net } \\
\text { stock }\end{array}$ & $\begin{array}{l}\text { Gross } \\
\text { stock }\end{array}$ & $\begin{array}{c}\text { Net } \\
\text { stock }\end{array}$ & $\begin{array}{l}\text { Gross } \\
\text { stock }\end{array}$ & $\begin{array}{c}\text { Net } \\
\text { stock }\end{array}$ & $\begin{array}{l}\text { Gross } \\
\text { stock }\end{array}$ & $\begin{array}{l}\text { Net } \\
\text { stock }\end{array}$ \\
\hline 1970 & 21646 & 17582 & 9277 & 7028 & 1400 & 971 & 32323 & 25581 \\
\hline 1971 & 22626 & 17661 & 9739 & 7042 & 1394 & 893 & 33758 & 25596 \\
\hline 1972 & 23536 & 18678 & 11082 & 7842 & 1343 & 838 & 35962 & 27357 \\
\hline 1973 & 24105 & 19636 & 13720 & 10120 & 1369 & 765 & 39195 & 30521 \\
\hline 1974 & 24517 & 20266 & 15982 & 11659 & 1448 & 799 & 41947 & 32724 \\
\hline 1975 & 24291 & 20759 & 17761 & 12958 & 1479 & 884 & 43531 & 34600 \\
\hline 1976 & 24171 & 20648 & 19158 & 13751 & 1601 & 904 & 44931 & 35303 \\
\hline 1977 & 23965 & 20699 & 21057 & 14776 & 2044 & 1008 & 47067 & 36483 \\
\hline 1978 & 23320 & 20719 & 23083 & 16068 & 2305 & 1421 & 48707 & 38208 \\
\hline 1979 & 23073 & 20349 & 25125 & 17021 & 2460 & 1601 & 50658 & 38971 \\
\hline 1980 & 22875 & 20373 & 27527 & 18517 & 2654 & 1676 & 53057 & 40566 \\
\hline 1981 & 22564 & 20428 & 29442 & 19613 & 3035 & 1812 & 55041 & 41853 \\
\hline 1982 & 22297 & 20332 & 30618 & 19693 & 3347 & 2111 & 56263 & 42136 \\
\hline 1983 & 22127 & 20247 & 30884 & 19662 & 3583 & 2296 & 56594 & 42205 \\
\hline 1984 & 21843 & 20231 & 30860 & 18750 & 3685 & 2365 & 56388 & 41347 \\
\hline 1985 & 21449 & 20070 & 31322 & 17716 & 3830 & 2275 & 56600 & 40061 \\
\hline 1986 & 21892 & 19780 & 33574 & 18138 & 4061 & 2229 & 59527 & 40147 \\
\hline 1987 & 22543 & 20312 & 33857 & 16752 & 5143 & 2292 & 61544 & 39355 \\
\hline 1988 & 23165 & 21019 & 36161 & 17305 & 5630 & 3232 & 64956 & 41556 \\
\hline 1989 & 23754 & 21676 & 39688 & 18098 & 6011 & 3562 & 69453 & 43336 \\
\hline 1990 & 24580 & 22290 & 44872 & 20401 & 6303 & 3790 & 75755 & 46482 \\
\hline 1991 & 24548 & 23155 & 48835 & 23824 & 6747 & 3921 & 80130 & 50900 \\
\hline 1992 & 24757 & 23149 & 49434 & 23520 & 6928 & 4230 & 81118 & 50899 \\
\hline 1993 & 25427 & 23375 & 50142 & 24354 & 7061 & 4298 & 82630 & 52028 \\
\hline 1994 & 26625 & 24037 & 51515 & 24820 & 6938 & 4292 & 85078 & 53149 \\
\hline 1995 & 26345 & 25179 & 53573 & 24906 & 7332 & 4030 & 87249 & 54115 \\
\hline 1996 & 26161 & 24786 & 52922 & 23455 & 7445 & 4302 & 86528 & 52544 \\
\hline 1997 & 25695 & 24484 & 50772 & 22611 & 7670 & 4239 & 84137 & 51334 \\
\hline
\end{tabular}


Table D.8: Gross and Net Capital Stocks, Transport Services, 1970-97 (million 1980 French francs)

\begin{tabular}{|c|c|c|c|c|c|c|c|c|}
\hline & \multicolumn{2}{|c|}{$\begin{array}{l}\text { Non-residential } \\
\text { structures }\end{array}$} & \multicolumn{2}{|c|}{$\begin{array}{l}\text { Transport } \\
\text { equipment }\end{array}$} & \multicolumn{2}{|c|}{$\begin{array}{l}\text { Other machinery } \\
\text { \& equipment }\end{array}$} & \multicolumn{2}{|c|}{ All assets } \\
\hline & $\begin{array}{l}\text { Gross } \\
\text { stock }\end{array}$ & $\begin{array}{l}\text { Net } \\
\text { stock }\end{array}$ & $\begin{array}{l}\text { Gross } \\
\text { stock }\end{array}$ & $\begin{array}{l}\text { Net } \\
\text { stock }\end{array}$ & $\begin{array}{l}\text { Gross } \\
\text { stock }\end{array}$ & $\begin{array}{l}\text { Net } \\
\text { stock }\end{array}$ & $\begin{array}{l}\text { Gross } \\
\text { stock }\end{array}$ & $\begin{array}{c}\text { Net } \\
\text { stock }\end{array}$ \\
\hline 1970 & 140355 & 110915 & 529 & 404 & 1435 & 906 & 142320 & 112225 \\
\hline 1971 & 146532 & 117345 & 602 & 462 & 1627 & 1030 & 148760 & 118836 \\
\hline 1972 & 152604 & 123805 & 676 & 518 & 1809 & 1146 & 155089 & 125468 \\
\hline 1973 & 159508 & 131309 & 781 & 604 & 2003 & 1263 & 162292 & 133176 \\
\hline 1974 & 166669 & 139335 & 924 & 724 & 2226 & 1399 & 169820 & 141458 \\
\hline 1975 & 175047 & 148835 & 1030 & 802 & 2449 & 1519 & 178526 & 151157 \\
\hline 1976 & 180594 & 155693 & 1127 & 868 & 2708 & 1664 & 184429 & 158225 \\
\hline 1977 & 185278 & 161896 & 1242 & 950 & 2904 & 1737 & 189424 & 164584 \\
\hline 1978 & 188008 & 165929 & 1317 & 990 & 3023 & 1738 & 192347 & 168657 \\
\hline 1979 & 190631 & 169555 & 1410 & 1047 & 3101 & 1719 & 195142 & 172320 \\
\hline 1980 & 191336 & 170903 & 1486 & 1084 & 3149 & 1691 & 195970 & 173678 \\
\hline 1981 & 194304 & 174299 & 1599 & 1159 & 3212 & 1700 & 199115 & 177158 \\
\hline 1982 & 196338 & 176521 & 1670 & 1188 & 3180 & 1635 & 201187 & 179345 \\
\hline 1983 & 197129 & 177365 & 1723 & 1201 & 3100 & 1551 & 201952 & 180117 \\
\hline 1984 & 197783 & 177935 & 1760 & 1201 & 3004 & 1479 & 202547 & 180615 \\
\hline 1985 & 198265 & 178177 & 1844 & 1253 & 2904 & 1436 & 203013 & 180866 \\
\hline 1986 & 199206 & 178736 & 1904 & 1282 & 2795 & 1413 & 203906 & 181432 \\
\hline 1987 & 200782 & 179838 & 1976 & 1328 & 2736 & 1462 & 205493 & 182628 \\
\hline 1988 & 203315 & 181759 & 2031 & 1362 & 2719 & 1555 & 208065 & 184676 \\
\hline 1989 & 207239 & 184831 & 2103 & 1418 & 2681 & 1607 & 212023 & 187857 \\
\hline 1990 & 212104 & 188533 & 2163 & 1471 & 2653 & 1644 & 216920 & 191647 \\
\hline 1991 & 218018 & 192998 & 2226 & 1538 & 2652 & 1682 & 222896 & 196217 \\
\hline 1992 & 224820 & 198099 & 2267 & 1588 & 2674 & 1714 & 229761 & 201401 \\
\hline 1993 & 232134 & 203530 & 2313 & 1648 & 2744 & 1764 & 237192 & 206942 \\
\hline 1994 & 239110 & 208663 & 2455 & 1810 & 2860 & 1834 & 244425 & 212307 \\
\hline 1995 & 246802 & 214655 & 2464 & 1832 & 2984 & 1887 & 252250 & 218374 \\
\hline 1996 & 255676 & 221962 & 2463 & 1847 & 3027 & 1844 & 261166 & 225653 \\
\hline 1997 & 265633 & 230434 & 2346 & 1743 & 2882 & 1604 & 270861 & 233780 \\
\hline
\end{tabular}


Table D.9: Gross and Net Capital Stocks, Total Transport, 1970-97 (million 1980 French francs)

\begin{tabular}{|c|c|c|c|c|c|c|c|c|}
\hline & \multicolumn{2}{|c|}{$\begin{array}{c}\text { Non-residential } \\
\text { structures }\end{array}$} & \multicolumn{2}{|c|}{$\begin{array}{l}\text { Transport } \\
\text { equipment }\end{array}$} & \multicolumn{2}{|c|}{$\begin{array}{l}\text { Other machinery } \\
\text { \& equipment }\end{array}$} & \multicolumn{2}{|c|}{ All assets } \\
\hline & $\begin{array}{l}\text { Gross } \\
\text { stock }\end{array}$ & $\begin{array}{l}\text { Net } \\
\text { stock }\end{array}$ & $\begin{array}{l}\text { Gross } \\
\text { stock }\end{array}$ & $\begin{array}{c}\text { Net } \\
\text { stock }\end{array}$ & $\begin{array}{l}\text { Gross } \\
\text { stock }\end{array}$ & $\begin{array}{l}\text { Net } \\
\text { stock }\end{array}$ & $\begin{array}{l}\text { Gross } \\
\text { stock }\end{array}$ & $\begin{array}{l}\text { Net } \\
\text { stock }\end{array}$ \\
\hline 1970 & 301412 & 242427 & 127485 & 83098 & 31254 & 18641 & 460151 & 344166 \\
\hline 1971 & 315915 & 254292 & 134307 & 86829 & 31887 & 18624 & 482109 & 359746 \\
\hline 1972 & 329565 & 266376 & 141230 & 90991 & 32393 & 18839 & 503189 & 376206 \\
\hline 1973 & 342852 & 278539 & 151180 & 98077 & 34515 & 20225 & 528547 & 396841 \\
\hline 1974 & 356035 & 290652 & 163592 & 106415 & 35926 & 20863 & 555553 & 417930 \\
\hline 1975 & 370300 & 304590 & 173078 & 111879 & 37522 & 21880 & 580899 & 438349 \\
\hline 1976 & 381599 & 315007 & 182518 & 118018 & 38437 & 22186 & 602553 & 455212 \\
\hline 1977 & 393706 & 326676 & 194621 & 125790 & 38758 & 21832 & 627085 & 474298 \\
\hline 1978 & 402773 & 335441 & 201046 & 128385 & 38601 & 21617 & 642420 & 485443 \\
\hline 1979 & 413294 & 344453 & 205781 & 129306 & 38021 & 21149 & 657096 & 494907 \\
\hline 1980 & 421407 & 350895 & 211896 & 130506 & 37596 & 20658 & 670898 & 502059 \\
\hline 1981 & 431663 & 359284 & 215232 & 129936 & 37395 & 20482 & 684290 & 509702 \\
\hline 1982 & 440931 & 366111 & 219740 & 129849 & 37065 & 20427 & 697735 & 516387 \\
\hline 1983 & 448729 & 371159 & 220678 & 128008 & 36502 & 20491 & 705908 & 519658 \\
\hline 1984 & 455650 & 375281 & 219624 & 124712 & 35795 & 20214 & 711069 & 520208 \\
\hline 1985 & 462178 & 378734 & 218020 & 121427 & 34548 & 19925 & 714746 & 520086 \\
\hline 1986 & 470513 & 382842 & 220069 & 121293 & 34396 & 19357 & 724978 & 523492 \\
\hline 1987 & 480320 & 388892 & 218782 & 119220 & 34127 & 19807 & 733228 & 527918 \\
\hline 1988 & 490647 & 395728 & 221349 & 120184 & 34095 & 20570 & 746091 & 536482 \\
\hline 1989 & 501848 & 403262 & 226166 & 122815 & 34605 & 21181 & 762619 & 547258 \\
\hline 1990 & 515722 & 413003 & 231617 & 126455 & 35374 & 22184 & 782712 & 561641 \\
\hline 1991 & 530836 & 424946 & 237269 & 131867 & 36786 & 23088 & 804891 & 579901 \\
\hline 1992 & 546414 & 436119 & 244392 & 137755 & 38702 & 25191 & 829508 & 599066 \\
\hline 1993 & 561941 & 446968 & 246909 & 139772 & 39626 & 25528 & 848476 & 612268 \\
\hline 1994 & 575459 & 455922 & 249632 & 140747 & 40307 & 25735 & 865398 & 622404 \\
\hline 1995 & 587546 & 465757 & 254330 & 142512 & 41628 & 25720 & 883504 & 633989 \\
\hline 1996 & 601596 & 476311 & 258175 & 143302 & 42823 & 26268 & 902593 & 645881 \\
\hline 1997 & 612940 & 484825 & 255284 & 139708 & 43275 & 25790 & 911499 & 650324 \\
\hline
\end{tabular}


Table D.10: Indices of Capital Services (1993=100)

\begin{tabular}{|c|c|c|c|c|c|c|c|c|}
\hline & Railways & $\begin{array}{c}\text { Road } \\
\text { goods } \\
\text { transport }\end{array}$ & $\begin{array}{c}\text { Urban \& } \\
\text { interurban } \\
\text { passenger } \\
\text { transport }\end{array}$ & $\begin{array}{c}\text { Inland } \\
\text { water } \\
\text { transport }\end{array}$ & $\begin{array}{l}\text { Maritime } \\
\text { transport }\end{array}$ & $\begin{array}{c}\text { Air } \\
\text { transport }\end{array}$ & $\begin{array}{c}\text { Transport } \\
\text { services }\end{array}$ & TOTAL \\
\hline 1970 & 64.0 & 37.5 & 53.4 & 165.6 & 344.2 & 50.5 & 54.7 & 58.3 \\
\hline 1971 & 65.1 & 40.3 & 58.4 & 159.7 & 390.9 & 50.4 & 57.9 & 60.8 \\
\hline 1972 & 65.7 & 44.1 & 66.7 & 151.7 & 404.5 & 53.7 & 61.1 & 63.3 \\
\hline 1973 & 67.0 & 49.6 & 63.6 & 142.9 & 440.3 & 61.3 & 64.8 & 66.2 \\
\hline 1974 & 68.3 & 52.9 & 67.7 & 133.9 & 547.2 & 67.6 & 68.8 & 70.5 \\
\hline 1975 & 70.2 & 52.4 & 70.9 & 127.3 & 602.9 & 72.7 & 73.4 & 73.9 \\
\hline 1976 & 72.0 & 56.5 & 75.3 & 120.7 & 635.3 & 74.9 & 76.8 & 76.5 \\
\hline 1977 & 73.6 & 60.3 & 84.3 & 114.6 & 659.9 & 75.8 & 79.9 & 79.6 \\
\hline 1978 & 75.2 & 63.2 & 86.5 & 108.9 & 607.1 & 78.1 & 81.8 & 81.2 \\
\hline 1979 & 76.6 & 63.0 & 91.3 & 103.9 & 525.0 & 81.0 & 83.5 & 82.9 \\
\hline 1980 & 78.0 & 64.8 & 94.8 & 99.1 & 484.4 & 85.7 & 84.1 & 84.1 \\
\hline 1981 & 79.9 & 64.0 & 96.7 & 97.2 & 422.2 & 89.2 & 85.8 & 84.7 \\
\hline 1982 & 81.3 & 65.7 & 97.5 & 94.2 & 403.2 & 90.5 & 86.8 & 85.4 \\
\hline 1983 & 82.7 & 66.2 & 96.5 & 96.1 & 357.7 & 91.0 & 87.1 & 85.8 \\
\hline 1984 & 83.6 & 67.0 & 94.2 & 95.3 & 301.7 & 88.9 & 87.3 & 85.5 \\
\hline 1985 & 84.0 & 66.5 & 90.7 & 86.8 & 256.4 & 85.3 & 87.4 & 85.0 \\
\hline 1986 & 85.2 & 68.2 & 87.7 & 82.4 & 148.1 & 92.3 & 87.7 & 85.4 \\
\hline 1987 & 85.9 & 72.2 & 90.0 & 82.8 & 153.3 & 71.3 & 88.3 & 85.9 \\
\hline 1988 & 87.4 & 77.2 & 90.7 & 77.1 & 110.8 & 76.9 & 89.3 & 87.1 \\
\hline 1989 & 88.7 & 86.8 & 90.8 & 81.4 & 93.8 & 80.5 & 90.9 & 88.9 \\
\hline 1990 & 91.0 & 89.6 & 91.5 & 83.3 & 90.8 & 87.7 & 92.7 & 91.4 \\
\hline 1991 & 94.2 & 89.9 & 93.0 & 85.9 & 93.8 & 97.4 & 94.9 & 94.6 \\
\hline 1992 & 98.2 & 96.9 & 96.8 & 95.9 & 112.4 & 97.8 & 97.4 & 97.9 \\
\hline 1993 & 100.0 & 100.0 & 100.0 & 100.0 & 100.0 & 100.0 & 100.0 & 100.0 \\
\hline 1994 & 100.8 & 102.4 & 102.3 & 103.7 & 92.8 & 102.0 & 102.6 & 101.5 \\
\hline 1995 & 101.3 & 109.6 & 103.7 & 108.2 & 94.6 & 102.9 & 105.5 & 103.1 \\
\hline 1996 & 102.8 & 112.1 & 105.3 & 109.3 & 102.7 & 99.1 & 108.9 & 104.7 \\
\hline 1997 & 104.8 & 92.5 & 103.7 & 101.1 & 106.9 & 96.7 & 112.4 & 104.3 \\
\hline
\end{tabular}




\section{ANNEX E - GDP, EMPLOYMENT, AND LABOUR SHARES IN FRANCE}

The time series for France were derived from the satellite accounts on transport (INSEE/Ministry of Transport, various issues, Les transports en 19..).

Table E.1: GDP at Constant Prices (million 1980 French francs)

\begin{tabular}{|c|c|c|c|c|c|c|c|c|}
\hline & Railways & $\begin{array}{c}\text { Road } \\
\text { goods } \\
\text { transport }\end{array}$ & $\begin{array}{c}\text { Urban \& } \\
\text { interurban } \\
\text { passenger } \\
\text { transport }\end{array}$ & $\begin{array}{c}\text { Inland } \\
\text { water } \\
\text { transport }\end{array}$ & $\begin{array}{l}\text { Maritime } \\
\text { transport }\end{array}$ & $\begin{array}{c}\text { Air } \\
\text { transport }\end{array}$ & $\begin{array}{c}\text { Transport } \\
\text { services }\end{array}$ & TOTAL \\
\hline 1970 & 16,916 & 18,167 & 13,608 & 685 & 2,953 & 2,409 & 17,892 & 72,630 \\
\hline 1971 & 16,315 & 19,731 & 14,337 & 684 & 3,239 & 2,551 & 19,576 & 76,433 \\
\hline 1972 & 17,080 & 20,793 & 15,665 & 646 & 3,668 & 4,050 & 21,550 & 83,452 \\
\hline 1973 & 17,614 & 23,791 & 16,835 & 625 & 3,515 & 4,776 & 23,314 & 90,470 \\
\hline 1974 & 19,025 & 24,432 & 17,950 & 686 & 5,041 & 3,465 & 24,917 & 95,516 \\
\hline 1975 & 17,493 & 23,299 & 17,563 & 627 & 4,370 & 4,689 & 25,703 & 93,744 \\
\hline 1976 & 18,459 & 23,393 & 17,839 & 677 & 4,398 & 5,353 & 25,687 & 95,806 \\
\hline 1977 & 18,469 & 24,764 & 18,761 & 593 & 4,902 & 6,177 & 26,781 & 100,447 \\
\hline 1978 & 18,594 & 26,424 & 19,178 & 708 & 4,834 & 7,204 & 27,604 & 104,546 \\
\hline 1979 & 18,891 & 26,247 & 20,145 & 790 & 4,588 & 8,160 & 29,340 & 108,161 \\
\hline 1980 & 18,740 & 27,196 & 19,814 & 813 & 5,424 & 9,043 & 29,999 & 111,029 \\
\hline 1981 & 18,384 & 26,007 & 19,141 & 727 & 4,160 & 10,883 & 30,555 & 109,857 \\
\hline 1982 & 18,001 & 26,354 & 19,621 & 653 & 4,006 & 11,182 & 31,346 & 111,163 \\
\hline 1983 & 18,333 & 26,303 & 19,180 & 632 & 3,858 & 11,662 & 31,167 & 111,135 \\
\hline 1984 & 19,397 & 25,205 & 19,683 & 544 & 4,099 & 12,319 & 31,025 & 112,272 \\
\hline 1985 & 19,827 & 26,255 & 19,839 & 518 & 3,352 & 12,220 & 33,108 & 115,119 \\
\hline 1986 & 18,819 & 27,379 & 20,435 & 403 & 3,093 & 12,509 & 34,484 & 117,122 \\
\hline 1987 & 18,683 & 30,727 & 20,463 & 383 & 2,947 & 14,958 & 36,233 & 124,394 \\
\hline 1988 & 19,655 & 36,011 & 20,779 & 372 & 3,033 & 16,304 & 39,047 & 135,201 \\
\hline 1989 & 19,961 & 38,553 & 20,896 & 377 & 3,117 & 17,310 & 41,940 & 142,154 \\
\hline 1990 & 19,191 & 39,744 & 21,379 & 404 & 3,386 & 17,596 & 43,145 & 144,845 \\
\hline 1991 & 18,661 & 40,831 & 21,573 & 423 & 4,068 & 16,308 & 42,810 & 144,674 \\
\hline 1992 & 18,505 & 41,631 & 21,730 & 407 & 3,689 & 17,484 & 44,224 & 147,670 \\
\hline 1993 & 16,917 & 39,434 & 21,273 & 408 & 3,971 & 17,545 & 43,927 & 143,475 \\
\hline 1994 & 17,235 & 41,812 & 21,254 & 383 & 3,803 & 20,666 & 45,246 & 150,399 \\
\hline 1995 & 16,611 & 45,917 & 21,159 & 400 & 3,733 & 20,352 & 46,760 & 154,932 \\
\hline 1996 & 17,226 & 45,252 & 21,620 & 392 & 3,503 & 24,193 & 47,252 & 159,438 \\
\hline 1997 & 18,162 & 47,154 & 22,056 & 389 & 3,601 & 25,265 & 48,735 & 165,362 \\
\hline
\end{tabular}


Table E.2: GDP at Current Prices (million French francs)

\begin{tabular}{|c|c|c|c|c|c|c|c|c|c|}
\hline & \multirow[t]{2}{*}{ Railways } & \multirow[t]{2}{*}{$\begin{array}{c}\text { Road } \\
\text { goods } \\
\text { transport }\end{array}$} & \multicolumn{2}{|c|}{$\begin{array}{c}\text { Urban \& } \\
\text { interurban } \\
\text { passenger } \\
\text { transport }\end{array}$} & \multirow[t]{2}{*}{$\begin{array}{c}\text { Inland } \\
\text { water } \\
\text { transport }\end{array}$} & \multirow[t]{2}{*}{$\begin{array}{l}\text { Maritime } \\
\text { transport }\end{array}$} & \multirow[t]{2}{*}{$\begin{array}{c}\text { Air } \\
\text { transport }\end{array}$} & \multirow[t]{2}{*}{$\begin{array}{l}\text { Transpor } \\
\text { t services }\end{array}$} & \multirow[t]{2}{*}{ TOTAL } \\
\hline & & & TOTAL & $\begin{array}{l}\text { f which: } \\
\text { RATP }\end{array}$ & & & & & \\
\hline 1970 & 13,286 & 5,276 & 4,942 & 1,848 & n.a. & 1,990 & 2,414 & n.a. & 27,908 \\
\hline 1971 & 14,097 & 5,895 & 5,587 & 1,989 & n.a. & 2,192 & 2,681 & n.a. & 30,452 \\
\hline 1972 & 14,612 & 6,577 & 6,330 & 2,186 & n.a. & 2,257 & 3,166 & n.a. & 32,942 \\
\hline 1973 & 16,540 & 8,145 & 7,441 & 2,460 & n.a. & 2,490 & 3,386 & n.a. & 38,002 \\
\hline 1974 & 19,224 & 9,366 & 8,083 & 2,494 & n.a. & 3,291 & 3,413 & n.a. & 43,377 \\
\hline 1975 & 20,897 & 10,199 & 10,594 & 2,930 & n.a. & 3,194 & 4,575 & n.a. & 49,459 \\
\hline 1976 & 22,218 & 11,910 & 12,265 & 3,349 & n.a. & 3,699 & 5,538 & n.a. & 55,630 \\
\hline 1977 & 24,907 & 13,655 & 14,487 & 3,866 & n.a. & 4,098 & 6,995 & n.a. & 64,142 \\
\hline 1978 & 27,488 & 15,533 & 14,786 & 4,424 & n.a. & 4,010 & 8,473 & n.a. & 70,290 \\
\hline 1979 & 31,548 & 18,450 & n.a. & 5,014 & 364 & 4,211 & 9,398 & n.a. & 68,985 \\
\hline 1980 & 34,444 & 21,087 & n.a. & 5,855 & 416 & 4,701 & 10,561 & n.a. & 77,064 \\
\hline 1981 & 38,563 & 23,478 & n.a. & 7,082 & 410 & 5,199 & 12,239 & n.a. & 86,971 \\
\hline 1982 & 43,124 & 26,900 & n.a. & 8,185 & 457 & 4,916 & 14,067 & n.a. & 97,649 \\
\hline 1983 & 45,887 & 29,472 & n.a. & 9,468 & 504 & 5,232 & 16,941 & n.a. & 107,504 \\
\hline 1984 & 53,427 & 30,874 & n.a. & 10,360 & 515 & 5,751 & 18,865 & n.a. & 119,792 \\
\hline 1985 & 56,694 & 31,809 & n.a. & 11,293 & 382 & 6,025 & 20,433 & n.a. & 126,636 \\
\hline 1986 & 56,486 & 36,156 & n.a. & 12,104 & 296 & 5,441 & 21,811 & n.a. & 132,294 \\
\hline 1987 & 57,465 & 40,394 & n.a. & 12,398 & 405 & 4,401 & 21,913 & n.a. & 136,976 \\
\hline 1988 & 59,947 & 44,081 & n.a. & 12,808 & 566 & 5,090 & 23,351 & n.a. & 145,843 \\
\hline 1989 & 62,385 & 45,239 & n.a. & 12,439 & 705 & 5,013 & 23,112 & n.a. & 148,893 \\
\hline 1990 & 60,265 & 47,952 & n.a. & 12,862 & 449 & 4,348 & 21,930 & n.a. & 147,806 \\
\hline 1991 & 58,327 & 49,964 & n.a. & 13,285 & 467 & 5,090 & 24,382 & n.a. & 151,515 \\
\hline 1992 & 60,129 & 71,921 & 57,805 & 14,210 & 453 & 4,448 & 27,825 & 71,625 & 222,581 \\
\hline 1993 & 56,830 & 70,302 & 58,778 & 14,350 & 537 & 4,323 & 26,059 & 71,258 & 216,829 \\
\hline 1994 & 56,914 & 73,239 & 61,762 & 15,074 & 507 & 3,692 & 29,164 & 73,938 & 225,278 \\
\hline 1995 & 54,859 & 76,172 & 61,433 & 15,448 & 503 & 2,587 & 27,268 & 77,949 & 222,822 \\
\hline 1996 & 58,913 & 74,571 & 68,505 & 16,269 & 478 & 3,511 & 27,153 & 78,056 & 233,131 \\
\hline 1997 & 60,957 & 80,792 & 68,696 & 16,716 & 549 & 4,030 & 30,552 & 95,644 & 245,576 \\
\hline
\end{tabular}


Table E.3: Labour Compensation at Current Prices (million French francs)

\begin{tabular}{|c|c|c|c|c|c|c|c|c|c|}
\hline & Railways & $\begin{array}{c}\text { Road } \\
\text { goods } \\
\text { transport }\end{array}$ & $\begin{array}{r}\text { Urb } \\
\text { inter } \\
\text { pass } \\
\text { tran }\end{array}$ & $\begin{array}{l}\text { in \& } \\
\text { rrban } \\
\text { nger } \\
\text { port } \\
\text { of which: } \\
\text { RATP }\end{array}$ & $\begin{array}{c}\text { Inland } \\
\text { water } \\
\text { transport }\end{array}$ & $\begin{array}{l}\text { Maritime } \\
\text { transport }\end{array}$ & $\begin{array}{c}\text { Air } \\
\text { transport }\end{array}$ & $\begin{array}{l}\text { Transpor } \\
\text { t services }\end{array}$ & TOTAL \\
\hline 1970 & 8,381 & 2,003 & 3,184 & 1,404 & n.a. & 1,347 & 1,540 & n.a. & 16,455 \\
\hline 1971 & 8,947 & 2,353 & 3,548 & 1,537 & n.a. & 1,496 & 1,770 & n.a. & 18,114 \\
\hline 1972 & 9,763 & 2,678 & 3,888 & 1,677 & n.a. & 1,524 & 2,047 & n.a. & 19,900 \\
\hline 1973 & 10,777 & 3,351 & 4,494 & 1,875 & n.a. & 1,735 & 2,349 & n.a. & 22,706 \\
\hline 1974 & 12,631 & 4,058 & 5,460 & 2,143 & n.a. & 1,942 & 2,760 & n.a. & 26,851 \\
\hline 1975 & 14,691 & 4,692 & 6,552 & 2,521 & n.a. & 2,197 & 3,335 & n.a. & 31,467 \\
\hline 1976 & 16,990 & 5,500 & 7,636 & 2,867 & n.a. & 2,872 & 3,930 & n.a. & 36,928 \\
\hline 1977 & 19,062 & 6,772 & 8,453 & 3,281 & n.a. & 2,975 & 4,522 & n.a. & 41,784 \\
\hline 1978 & 20,706 & 7,717 & 9,670 & 3,642 & n.a. & 3,076 & 5,243 & n.a. & 46,412 \\
\hline 1979 & 23,106 & 9,320 & n.a. & 4,134 & 252 & 3,461 & 5,949 & n.a. & 46,222 \\
\hline 1980 & 26,261 & 11,019 & n.a. & 4,745 & 294 & 3,742 & 7,073 & n.a. & 53,134 \\
\hline 1981 & 29,726 & 12,617 & n.a. & 5,481 & 336 & 3,990 & 8,003 & n.a. & 60,153 \\
\hline 1982 & 34,175 & 14,816 & n.a. & 6,409 & 350 & 4,448 & 9,370 & n.a. & 69,568 \\
\hline 1983 & 37,455 & 16,340 & n.a. & 7,319 & 389 & 4,735 & 10,565 & n.a. & 76,803 \\
\hline 1984 & 38,366 & 17,370 & n.a. & 7,839 & 368 & 4,702 & 11,567 & n.a. & 80,212 \\
\hline 1985 & 39,734 & 17,925 & n.a. & 8,402 & 301 & 4,855 & 12,523 & n.a. & 83,740 \\
\hline 1986 & 39,471 & 19,411 & n.a. & 8,622 & 260 & 4,315 & 13,292 & n.a. & 85,371 \\
\hline 1987 & 39,182 & 23,014 & n.a. & 8,821 & 329 & 3,965 & 13,683 & n.a. & 88,994 \\
\hline 1988 & 39,448 & 25,164 & n.a. & 9,029 & 341 & 3,770 & 14,790 & n.a. & 92,542 \\
\hline 1989 & 40,725 & 27,064 & n.a. & 9,636 & 370 & 3,352 & 16,112 & n.a. & 97,259 \\
\hline 1990 & 40,946 & 29,164 & n.a. & 9,989 & 344 & 3,466 & 17,579 & n.a. & 101,488 \\
\hline 1991 & 42,122 & 31,165 & n.a. & 10,319 & 366 & 4,063 & 18,223 & n.a. & 106,258 \\
\hline 1992 & 43,811 & 41,120 & 32,030 & 10,739 & 378 & 3,740 & 21,463 & n.a. & 121,251 \\
\hline 1993 & 44,006 & 41,428 & 32,668 & 10,966 & 379 & 3,536 & 21,041 & n.a. & 121,356 \\
\hline 1994 & 43,920 & 42,406 & 33,824 & 11,219 & 344 & 3,247 & 20,515 & n.a. & 121,651 \\
\hline 1995 & 43,886 & 45,181 & 33,962 & 11,407 & 331 & 3,168 & 19,726 & n.a. & 123,699 \\
\hline 1996 & 44,460 & 45,953 & 36,960 & 11,757 & 338 & 3,239 & 20,260 & n.a. & 126,007 \\
\hline 1997 & 45,337 & 49,491 & 38,323 & 11,999 & 336 & 3,216 & 21,056 & n.a. & 131,435 \\
\hline
\end{tabular}


Table E.4: Share of Labour Compensation in Value Added

\begin{tabular}{|c|c|c|c|c|c|c|c|c|}
\hline & \multirow[t]{2}{*}{ Railways } & \multirow[t]{2}{*}{$\begin{array}{c}\text { Road } \\
\text { goods } \\
\text { transport }\end{array}$} & \multicolumn{2}{|c|}{$\begin{array}{c}\text { Urban \& } \\
\text { interurban } \\
\text { passenger } \\
\text { transport }\end{array}$} & \multirow[t]{2}{*}{$\begin{array}{c}\text { Inland } \\
\text { water } \\
\text { transport }\end{array}$} & \multirow[t]{2}{*}{$\begin{array}{l}\text { Maritime } \\
\text { transport }\end{array}$} & \multirow[t]{2}{*}{$\underset{\text { transport }}{\text { Air }}$} & \multirow[t]{2}{*}{$\begin{array}{c}\text { Transpor } \\
\mathbf{t} \\
\text { services* }\end{array}$ TOTAL } \\
\hline & & & OTAL & $\begin{array}{l}\text { f which: } \\
\text { RATP }\end{array}$ & & & & \\
\hline 1970 & 0.63 & 0.38 & 0.64 & 0.59 & 0.68 & 0.64 & 0.59 & 0.59 \\
\hline 1971 & 0.63 & 0.40 & 0.64 & 0.59 & 0.68 & 0.66 & 0.59 & 0.59 \\
\hline 1972 & 0.67 & 0.41 & 0.61 & 0.58 & 0.68 & 0.65 & 0.60 & 0.60 \\
\hline 1973 & 0.65 & 0.41 & 0.60 & 0.60 & 0.70 & 0.69 & 0.60 & 0.60 \\
\hline 1974 & 0.66 & 0.43 & 0.68 & 0.51 & 0.59 & 0.81 & 0.62 & 0.62 \\
\hline 1975 & 0.70 & 0.46 & 0.62 & 0.60 & 0.69 & 0.73 & 0.64 & 0.64 \\
\hline 1976 & 0.76 & 0.46 & 0.62 & 0.67 & 0.78 & 0.71 & 0.66 & 0.66 \\
\hline 1977 & 0.77 & 0.50 & 0.58 & 0.63 & 0.73 & 0.65 & 0.65 & 0.65 \\
\hline 1978 & 0.75 & 0.50 & 0.65 & 0.66 & 0.77 & 0.62 & 0.66 & 0.66 \\
\hline 1979 & 0.73 & 0.51 & 0.65 & 0.69 & 0.82 & 0.63 & 0.67 & 0.67 \\
\hline 1980 & 0.76 & 0.52 & 0.64 & 0.71 & 0.80 & 0.67 & 0.69 & $\begin{array}{l}0.69 \\
0.69\end{array}$ \\
\hline 1981 & 0.77 & 0.54 & 0.61 & 0.82 & 0.77 & 0.65 & 0.69 & 0.71 \\
\hline 1982 & 0.79 & 0.55 & 0.62 & 0.77 & 0.90 & 0.67 & 0.71 & 0.71 \\
\hline 1983 & 0.82 & 0.55 & 0.61 & 0.77 & 0.91 & 0.62 & 0.71 & 0.67 \\
\hline 1984 & 0.72 & 0.56 & 0.60 & 0.71 & 0.82 & 0.61 & 0.67 & 0.66 \\
\hline 1985 & 0.70 & 0.56 & 0.59 & 0.79 & 0.81 & 0.61 & 0.66 & 0.65 \\
\hline 1986 & 0.70 & 0.54 & 0.56 & 0.88 & 0.79 & 0.61 & 0.65 & 0.65 \\
\hline 1987 & 0.68 & 0.57 & 0.56 & 0.81 & 0.90 & 0.62 & 0.65 & 0.63 \\
\hline 1988 & 0.66 & 0.57 & 0.56 & 0.60 & 0.74 & 0.63 & 0.63 & 0.65 \\
\hline 1989 & 0.65 & 0.60 & 0.61 & 0.52 & 0.67 & 0.70 & 0.65 & 0.69 \\
\hline 1990 & 0.68 & 0.61 & 0.61 & 0.77 & 0.80 & 0.80 & 0.69 & 0.70 \\
\hline 1991 & 0.72 & 0.62 & 0.61 & 0.78 & 0.80 & 0.75 & 0.70 & 0.54 \\
\hline 1992 & 0.73 & 0.57 & 0.55 & 0.83 & 0.84 & 0.77 & 0.54 & 0.56 \\
\hline 1993 & 0.77 & 0.59 & 0.56 & 0.71 & 0.82 & 0.81 & 0.56 & 0.54 \\
\hline 1994 & 0.77 & 0.58 & 0.55 & 0.68 & 0.88 & 0.70 & 0.54 & 0.56 \\
\hline 1995 & 0.80 & 0.59 & 0.55 & 0.66 & 0.88 & 0.72 & 0.56 & 0.54 \\
\hline 1996 & 0.75 & 0.62 & 0.54 & 0.71 & 0.88 & 0.75 & 0.54 & 0.54 \\
\hline 1997 & 0.74 & 0.61 & 0.56 & 0.61 & 0.88 & 0.69 & 0.54 & \\
\hline
\end{tabular}

*The labour income shares in transport services and total transport were estimated by the weighted average of labour income shares of the other sub-sectors. 
Table E.5: Persons Engaged (000s) in Transport by Branch

\begin{tabular}{|c|c|c|c|c|c|c|c|c|}
\hline & Railways & $\begin{array}{c}\text { Road } \\
\text { goods } \\
\text { transport }\end{array}$ & $\begin{array}{c}\text { Urban \& } \\
\text { interurba } \\
n \\
\text { passenger } \\
\text { transport }\end{array}$ & $\begin{array}{c}\text { Inland } \\
\text { water } \\
\text { transport }\end{array}$ & $\begin{array}{l}\text { Maritime } \\
\text { transport }\end{array}$ & $\begin{array}{c}\text { Air } \\
\text { transport }\end{array}$ & $\begin{array}{c}\text { Transport } \\
\text { services }\end{array}$ & TOTAL \\
\hline 1970 & 303.0 & 185.9 & 159.8 & 8.6 & 26.5 & 31.2 & 128.5 & 843.5 \\
\hline 1971 & 296.4 & 188.5 & 160.8 & 8.5 & 27.0 & 32.6 & 130.6 & 844.4 \\
\hline 1972 & 289.3 & 193.5 & 163.5 & 8.6 & 27.9 & 34.3 & 134.4 & 851.5 \\
\hline 1973 & 285.4 & 198.8 & 166.5 & 8.7 & 28.8 & 36.1 & 138.3 & 862.6 \\
\hline 1974 & 284.6 & 205.5 & 170.8 & 8.9 & 29.8 & 37.4 & 143.1 & 880.1 \\
\hline 1975 & 281.7 & 202.3 & 170.4 & 8.8 & 28.2 & 37.4 & 146.1 & 874.9 \\
\hline 1976 & 274.1 & 203.5 & 171.6 & 8.4 & 27.9 & 37.8 & 147.9 & 871.2 \\
\hline 1977 & 268.8 & 204.4 & 175.1 & 8.2 & 28.1 & 38.9 & 153.0 & 876.5 \\
\hline 1978 & 263.0 & 204.5 & 177.4 & 8.0 & 27.1 & 41.0 & 158.3 & 879.3 \\
\hline 1979 & 258.9 & 204.4 & 178.9 & 8.0 & 26.5 & 43.3 & 161.2 & 881.2 \\
\hline 1980 & 254.4 & 204.5 & 180.9 & 7.8 & 25.4 & 45.8 & 165.0 & 883.8 \\
\hline 1981 & 248.5 & 202.6 & 181.7 & 7.5 & 23.9 & 48.0 & 167.6 & 879.8 \\
\hline 1982 & 252.4 & 203.6 & 184.9 & 7.1 & 22.5 & 51.3 & 172.6 & 894.4 \\
\hline 1983 & 252.2 & 206.0 & 187.7 & 6.1 & 22.3 & 52.3 & 173.8 & 900.4 \\
\hline 1984 & 248.4 & 211.4 & 186.4 & 5.2 & 21.2 & 53.0 & 177.3 & 902.9 \\
\hline 1985 & 242.1 & 214.2 & 185.0 & 5.3 & 19.5 & 52.9 & 180.6 & 899.6 \\
\hline 1986 & 233.4 & 220.6 & 184.4 & 3.7 & 18.3 & 53.4 & 185.5 & 899.3 \\
\hline 1987 & 222.4 & 226.9 & 188.3 & 2.9 & 17.2 & 55.1 & 189.8 & 902.6 \\
\hline 1988 & 213.2 & 233.5 & 191.1 & 2.7 & 17.8 & 56.8 & 195.6 & 910.7 \\
\hline 1989 & 206.4 & 239.0 & 194.0 & 2.6 & 16.7 & 60.2 & 198.5 & 917.4 \\
\hline 1990 & 204.0 & 246.2 & 197.9 & 2.7 & 17.1 & 62.9 & 204.0 & 934.8 \\
\hline 1991 & 198.6 & 265.6 & 195.3 & 2.7 & 17.4 & 64.1 & 205.9 & 949.6 \\
\hline 1992 & 196.0 & 306.7 & 215.4 & 2.7 & 17.2 & 52.7 & 203.8 & 994.5 \\
\hline 1993 & 192.1 & 304.4 & 216.6 & 2.7 & 17.0 & 51.8 & 201.4 & 986.0 \\
\hline 1994 & 184.0 & 309.1 & 218.0 & 2.5 & 15.0 & 51.6 & 198.9 & 979.1 \\
\hline 1995 & 180.0 & 318.2 & 213.8 & 2.8 & 15.5 & 50.2 & 205.0 & 985.5 \\
\hline 1996 & 176.0 & 324.8 & 226.9 & 2.9 & 16.0 & 50.8 & 210.7 & $1,008.1$ \\
\hline 1997 & 174.0 & 328.4 & 226.7 & 2.9 & 16.1 & 50.2 & 214.2 & $1,012.5$ \\
\hline 1998 & 173.0 & 339.5 & 231.7 & 2.9 & 16.2 & 50.6 & 220.4 & $1,034.3$ \\
\hline
\end{tabular}

Note: The branch concept differs from the sector concept, as the latter includes only employment in firms for which that particular transport activity is their main business. The branch concept also covers workers engaged in the same activity but whose firm they belong to does not have this type of transport as their main business. The sector concept is preferred tot the branch concept, as the latter corresponds to the concept used for the construction of the other aggregates such as GDP. However, comprehensive employment series for all sub-sector do not exist. Nevertheless, the Transport Ministry confirmed that the employment estimates of both concepts are close for all transport activities except for railways. For this sector, series on a branch concept were used. 
Table E.6: Employees (000s) in Transport by branch

\begin{tabular}{|c|c|c|c|c|c|c|c|c|}
\hline & Railways & $\begin{array}{c}\text { Road } \\
\text { goods } \\
\text { transport }\end{array}$ & $\begin{array}{c}\text { Urban \& } \\
\text { interurba } \\
n \\
\text { passenger } \\
\text { transport }\end{array}$ & $\begin{array}{c}\text { Inland } \\
\text { water } \\
\text { transport }\end{array}$ & $\begin{array}{l}\text { Maritime } \\
\text { transport }\end{array}$ & $\begin{array}{c}\text { Air } \\
\text { transport }\end{array}$ & $\begin{array}{c}\text { Transport } \\
\text { services }\end{array}$ & TOTAL \\
\hline 1970 & 172.7 & 160.4 & 132.8 & 2.5 & 26.1 & 31.0 & 124.5 & 650.0 \\
\hline 1971 & 168.9 & 163.2 & 134.0 & 2.5 & 26.6 & 32.4 & 126.6 & 654.2 \\
\hline 1972 & 164.9 & 168.4 & 136.9 & 2.6 & 27.5 & 34.1 & 130.4 & 664.8 \\
\hline 1973 & 162.7 & 173.8 & 140.0 & 2.7 & 28.4 & 35.9 & 134.4 & 677.9 \\
\hline 1974 & 162.2 & 180.1 & 143.8 & 2.8 & 29.4 & 37.2 & 139.1 & 694.6 \\
\hline 1975 & 160.0 & 177.0 & 143.6 & 2.8 & 27.8 & 37.2 & 142.1 & 690.5 \\
\hline 1976 & 156.2 & 179.2 & 145.1 & 2.8 & 27.6 & 37.7 & 144.1 & 692.7 \\
\hline 1977 & 152.6 & 180.3 & 147.8 & 2.9 & 27.8 & 38.8 & 149.5 & 699.7 \\
\hline 1978 & 147.3 & 180.4 & 149.4 & 2.9 & 26.8 & 40.9 & 154.9 & 702.6 \\
\hline 1979 & 145.0 & 180.3 & 150.3 & 3.0 & 26.2 & 43.2 & 157.9 & 705.9 \\
\hline 1980 & 142.7 & 180.5 & 151.4 & 3.0 & 25.1 & 45.7 & 161.8 & 710.2 \\
\hline 1981 & 145.4 & 178.8 & 151.7 & 3.0 & 23.7 & 47.9 & 164.6 & 715.1 \\
\hline 1982 & 143.4 & 180.2 & 154.6 & 3.1 & 22.3 & 51.1 & 169.7 & 724.4 \\
\hline 1983 & 144.0 & 181.4 & 157.1 & 3.1 & 22.1 & 52.2 & 170.7 & 730.6 \\
\hline 1984 & 142.1 & 185.5 & 155.6 & 3.1 & 21.0 & 52.9 & 173.9 & 734.1 \\
\hline 1985 & 138.8 & 188.2 & 154.1 & 3.2 & 19.3 & 52.8 & 177.2 & 733.6 \\
\hline 1986 & 133.7 & 193.2 & 154.2 & 2.7 & 18.1 & 53.3 & 181.8 & 737.0 \\
\hline 1987 & 127.9 & 198.6 & 158.5 & 2.2 & 16.9 & 54.9 & 186.0 & 745.0 \\
\hline 1988 & 124.6 & 204.0 & 161.2 & 2.2 & 17.5 & 56.6 & 191.4 & 757.5 \\
\hline 1989 & 121.3 & 208.3 & 164.2 & 2.3 & 16.4 & 60.0 & 194.1 & 766.6 \\
\hline 1990 & 119.0 & 214.5 & 168.2 & 2.4 & 16.8 & 62.8 & 199.3 & 783.0 \\
\hline 1991 & 116.0 & 238.4 & 166.2 & 2.4 & 17.1 & 63.9 & 202.5 & 806.5 \\
\hline 1992 & 127.7 & 272.4 & 187.6 & 2.4 & 16.9 & 52.6 & 200.2 & 859.8 \\
\hline 1993 & 123.7 & 270.5 & 189.1 & 2.4 & 16.7 & 51.7 & 197.8 & 851.9 \\
\hline 1994 & 122.6 & 275.3 & 190.7 & 2.2 & 14.7 & 51.5 & 195.3 & 852.3 \\
\hline 1995 & 118.3 & 283.4 & 185.6 & 2.5 & 15.2 & 50.1 & 201.3 & 856.4 \\
\hline 1996 & 119.9 & 289.3 & 198.1 & 2.6 & 15.7 & 50.7 & 207.0 & 883.3 \\
\hline 1997 & 117.9 & 293.2 & 198.1 & 2.6 & 15.8 & 50.1 & 210.5 & 888.2 \\
\hline 1998 & 120.3 & 304.3 & 203.1 & 2.6 & 15.9 & 50.5 & 216.7 & 913.4 \\
\hline
\end{tabular}

Note: The branch concept differs from the sector concept, as the latter includes only employment in firms for which that particular transport activity is their main business. The branch concept also covers workers engaged in the same activity but whose firm they belong to does not have this type of transport as their main business. The sector concept is preferred tot the branch concept, as the latter corresponds to the concept used for the construction of the other aggregates such as GDP. However, comprehensive employment series for all sub-sector do not exist. Nevertheless, the Transport Ministry confirmed that 
Capital Stock and Productivity in French Transport : An International Comparison

the employment estimates of both concepts are close for all transport activities except for railways. For this sector, series on a branch concept were used. 
Table E.7: Annual Hours worked per Employee

\begin{tabular}{|c|c|c|c|c|c|c|c|c|}
\hline & Railways & $\begin{array}{c}\text { Road } \\
\text { goods } \\
\text { transport }\end{array}$ & $\begin{array}{c}\text { Urban \& } \\
\text { interurba } \\
n \\
\text { passenger } \\
\text { transport }\end{array}$ & $\begin{array}{c}\text { Inland } \\
\text { water } \\
\text { transport }\end{array}$ & $\begin{array}{l}\text { Maritime } \\
\text { transport }\end{array}$ & $\begin{array}{c}\text { Air } \\
\text { transport }\end{array}$ & $\begin{array}{c}\text { Transport } \\
\text { services }\end{array}$ & TOTAL \\
\hline 1970 & 1,953 & 2,169 & 2,050 & 2,416 & 2,102 & 1,956 & 1,940 & 2,041 \\
\hline 1971 & 1,910 & 2,124 & 2,008 & 2,400 & 2,059 & 1,911 & 1,899 & 1,998 \\
\hline 1972 & 1,871 & 2,084 & 1,983 & 2,395 & 2,022 & 1,872 & 1,894 & 1,969 \\
\hline 1973 & 1,830 & 2,046 & 1,921 & 2,345 & 1,986 & 1,831 & 1,819 & 1,919 \\
\hline 1974 & 1,808 & 2,011 & 1,886 & 2,303 & 1,953 & 1,807 & 1,780 & 1,887 \\
\hline 1975 & 1,770 & 1,937 & 1,874 & 2,261 & 1,875 & 1,769 & 1,786 & 1,851 \\
\hline 1976 & 1,788 & 1,968 & 1,891 & 2,274 & 1,909 & 1,789 & 1,808 & 1,875 \\
\hline 1977 & 1,780 & 1,937 & 1,875 & 2,241 & 1,875 & 1,782 & 1,782 & 1,853 \\
\hline 1978 & 1,770 & 1,933 & 1,868 & 2,235 & 1,871 & 1,770 & 1,770 & 1,845 \\
\hline 1979 & 1,771 & 1,931 & 1,867 & 2,210 & 1,872 & 1,772 & 1,769 & 1,844 \\
\hline 1980 & 1,758 & 1,929 & 1,879 & 2,190 & 1,867 & 1,757 & 1,793 & 1,847 \\
\hline 1981 & 1,740 & 1,916 & 1,858 & 2,160 & 1,852 & 1,741 & 1,765 & 1,827 \\
\hline 1982 & 1,682 & 1,841 & 1,797 & 2,100 & 1,777 & 1,682 & 1,693 & 1,760 \\
\hline 1983 & 1,684 & 1,834 & 1,781 & 2,100 & 1,772 & 1,683 & 1,660 & 1,747 \\
\hline 1984 & 1,663 & 1,821 & 1,803 & 2,098 & 1,751 & 1,663 & 1,711 & 1,754 \\
\hline 1985 & 1,645 & 1,814 & 1,787 & 2,107 & 1,743 & 1,647 & 1,689 & 1,739 \\
\hline 1986 & 1,634 & 1,791 & 1,772 & 2,086 & 1,734 & 1,636 & 1,686 & 1,727 \\
\hline 1987 & 1,632 & 1,801 & 1,762 & 2,076 & 1,750 & 1,635 & 1,680 & 1,727 \\
\hline 1988 & 1,660 & 1,835 & 1,762 & 2,197 & 1,829 & 1,661 & 1,638 & 1,737 \\
\hline 1989 & 1,639 & 1,808 & 1,772 & 2,182 & 1,799 & 1,641 & 1,652 & 1,730 \\
\hline 1990 & 1,646 & 1,818 & 1,766 & 1,852 & 1,754 & 1,647 & 1,617 & 1,721 \\
\hline 1991 & 1,646 & 1,838 & 1,776 & 1,852 & 1,782 & 1,640 & 1,599 & 1,725 \\
\hline 1992 & 1,659 & 1,695 & 1,956 & 1,852 & 1,744 & 1,632 & 1,601 & 1,721 \\
\hline 1993 & 1,664 & 1,698 & 1,951 & 1,852 & 1,765 & 1,622 & 1,615 & 1,725 \\
\hline 1994 & 1,679 & 1,705 & 1,956 & 2,000 & 1,800 & 1,609 & 1,640 & 1,736 \\
\hline 1995 & 1,647 & 1,678 & 1,950 & 1,724 & 1,742 & 1,594 & 1,651 & 1,721 \\
\hline 1996 & 1,650 & 1,681 & 1,933 & 1,786 & 1,750 & 1,594 & 1,563 & 1,700 \\
\hline 1997 & 1,653 & 1,687 & 1,943 & 1,786 & 1,750 & 1,574 & 1,566 & 1,704 \\
\hline 1998 & 1,653 & 1,688 & 1,940 & 1,786 & 1,750 & 1,561 & 1,564 & 1,703 \\
\hline
\end{tabular}





\section{ANNEX F - TIME SERIES FOR OTHER COUNTRIES}

The time series for Germany, the United Kingdom and the United States were taken from O’Mahony (1999). 
Table F.1: Index of Value Added at Constant Prices (1993=100)

\begin{tabular}{|c|c|c|c|c|c|c|c|c|c|c|c|}
\hline & \multicolumn{3}{|c|}{ Germany } & \multicolumn{3}{|c|}{ United Kingdom } & \multicolumn{5}{|c|}{ United States } \\
\hline & Transport & Railways & $\begin{array}{c}\text { Water } \\
\text { transport }\end{array}$ & Transport & Railways & $\begin{array}{c}\text { Air } \\
\text { transport }\end{array}$ & Transport & Railways & $\begin{array}{c}\text { Water } \\
\text { transport }\end{array}$ & $\underset{\text { Air }}{\text { transport }}$ & $\begin{array}{c}\text { Other inland } \\
\text { transport \& } \\
\text { transport services }\end{array}$ \\
\hline 1970 & 54.7 & 143.5 & 87.7 & 64.2 & 132.7 & 19.1 & 54.5 & 64.9 & 94.2 & 28.1 & 56.9 \\
\hline 1971 & 53.6 & 133.8 & 84.3 & 66.3 & 121.4 & 22.2 & 54.3 & 58.4 & 90.0 & 28.6 & 59.5 \\
\hline 1972 & 54.9 & 133.3 & 89.0 & 68.5 & 116.0 & 26.6 & 58.6 & 58.8 & 92.8 & 31.3 & 66.3 \\
\hline 1973 & 58.7 & 139.7 & 92.4 & 74.3 & 123.4 & 31.1 & 62.3 & 61.5 & 104.2 & 33.2 & 70.7 \\
\hline 1974 & 59.8 & 144.9 & 99.3 & 72.8 & 120.4 & 28.8 & 63.0 & 63.1 & 104.2 & 34.9 & 70.4 \\
\hline 1975 & 56.6 & 117.4 & 101.9 & 71.6 & 115.7 & 32.0 & 58.6 & 57.7 & 97.1 & 33.0 & 65.6 \\
\hline 1976 & 60.8 & 122.0 & 108.8 & 71.3 & 112.2 & 35.6 & 63.2 & 60.9 & 107.1 & 35.6 & 71.3 \\
\hline 1977 & 63.1 & 116.7 & 107.8 & 72.8 & 112.1 & 38.3 & 67.0 & 60.6 & 108.5 & 38.2 & 77.5 \\
\hline 1978 & 64.4 & 117.7 & 109.9 & 73.0 & 113.1 & 46.4 & 69.3 & 66.3 & 116.1 & 45.0 & 76.3 \\
\hline 1979 & 69.7 & 125.5 & 115.0 & 75.9 & 114.8 & 52.5 & 72.2 & 68.6 & 117.4 & 48.8 & 79.0 \\
\hline 1980 & 70.4 & 120.9 & 116.2 & 73.3 & 107.1 & 52.2 & 68.8 & 69.7 & 117.4 & 43.2 & 75.2 \\
\hline 1981 & 70.1 & 119.9 & 126.6 & 72.6 & 105.4 & 53.4 & 66.6 & 67.4 & 122.4 & 43.0 & 71.5 \\
\hline 1982 & 70.1 & 113.5 & 141.6 & 70.2 & 96.2 & 47.1 & 66.0 & 58.8 & 113.6 & 48.4 & 71.2 \\
\hline 1983 & 71.1 & 114.1 & 137.6 & 71.8 & 103.7 & 46.0 & 72.7 & 65.2 & 107.3 & 57.4 & 77.9 \\
\hline 1984 & 72.9 & 114.6 & 113.3 & 74.2 & 94.3 & 51.1 & 78.1 & 73.8 & 108.5 & 59.6 & 84.0 \\
\hline 1985 & 75.2 & 123.1 & 119.2 & 77.9 & 99.4 & 53.2 & 78.6 & 73.8 & 106.0 & 57.4 & 86.1 \\
\hline 1986 & 73.3 & 115.9 & 118.1 & 79.6 & 105.5 & 54.4 & 81.7 & 73.5 & 103.5 & 67.9 & 87.1 \\
\hline 1987 & 76.1 & 111.4 & 108.2 & 87.4 & 110.8 & 65.2 & 87.3 & 81.5 & 100.6 & 78.9 & 90.2 \\
\hline 1988 & 81.8 & 112.6 & 96.8 & 93.3 & 115.3 & 69.7 & 86.5 & 86.4 & 98.3 & 76.5 & 89.0 \\
\hline 1989 & 84.9 & 115.1 & 92.4 & 97.8 & 113.0 & 77.5 & 86.6 & 78.2 & 100.0 & 78.3 & 90.1 \\
\hline 1990 & 92.7 & 114.5 & 92.4 & 98.4 & 110.0 & 82.9 & 87.9 & 81.2 & 101.2 & 89.4 & 87.6 \\
\hline 1991 & 97.8 & 113.1 & 92.8 & 94.5 & 107.1 & 77.7 & 92.3 & 94.3 & 105.8 & 89.0 & 91.9 \\
\hline 1992 & 100.0 & 106.1 & 97.0 & 97.5 & 105.2 & 91.9 & 95.9 & 95.8 & 97.7 & 97.2 & 95.2 \\
\hline 1993 & 100.0 & 100.0 & 100.0 & 100.0 & 100.0 & 100.0 & 100.0 & 100.0 & 100.0 & 100.0 & 100.0 \\
\hline 1994 & 103.2 & 101.7 & 102.0 & 107.9 & 94.3 & 111.3 & 106.6 & 112.5 & 102.3 & 116.3 & 102.4 \\
\hline 1995 & 107.4 & 104.6 & 103.0 & 113.8 & 96.1 & 122.4 & 107.6 & 120.5 & 104.1 & 112.7 & 103.7 \\
\hline 1996 & 111.0 & & & 114.1 & 101.1 & 132.0 & 110.5 & 134.5 & 101.8 & 133.4 & 98.5 \\
\hline
\end{tabular}


Table F.2: Persons Engaged (000s)

\begin{tabular}{|c|c|c|c|c|c|c|c|c|c|c|c|}
\hline & \multicolumn{3}{|c|}{ Germany } & \multicolumn{3}{|c|}{ United Kingdom } & \multicolumn{5}{|c|}{ United States } \\
\hline & Transport & Railways & $\begin{array}{l}\text { Water } \\
\text { transport }\end{array}$ & Transport & Railways & $\begin{array}{c}\text { Air } \\
\text { transport }\end{array}$ & Transport & Railways & $\begin{array}{l}\text { Water } \\
\text { transport }\end{array}$ & $\begin{array}{c}\text { Air } \\
\text { transport }\end{array}$ & $\begin{array}{c}\text { Other inland } \\
\text { transport \& } \\
\text { transport } \\
\text { services } \\
\end{array}$ \\
\hline 1970 & 506 & 413 & 93 & 1,224 & 212 & 39 & 2,836 & 583 & 219 & 358 & 1,676 \\
\hline 1971 & 518 & 427 & 91 & 1,218 & 214 & 41 & 2,800 & 556 & 201 & 348 & 1,696 \\
\hline 1972 & 512 & 432 & 80 & 1,194 & 216 & 42 & 2,824 & 536 & 204 & 353 & 1,732 \\
\hline 1973 & 516 & 437 & 79 & 1,177 & 198 & 42 & 2,914 & 533 & 204 & 372 & 1,806 \\
\hline 1974 & 513 & 440 & 73 & 1,161 & 195 & 43 & 2,967 & 540 & 206 & 375 & 1,847 \\
\hline 1975 & 497 & 429 & 68 & 1,170 & 201 & 42 & 2,841 & 511 & 195 & 372 & 1,764 \\
\hline 1976 & 477 & 410 & 67 & 1,145 & 193 & 43 & 2,865 & 492 & 195 & 377 & 1,802 \\
\hline 1977 & 457 & 390 & 67 & 1,155 & 182 & 44 & 2,963 & 492 & 196 & 391 & 1,885 \\
\hline 1978 & 438 & 372 & 66 & 1,178 & 184 & 47 & 3,129 & 487 & 208 & 413 & 2,021 \\
\hline 1979 & 422 & 358 & 64 & 1,189 & 182 & 49 & 3,263 & 499 & 211 & 448 & 2,106 \\
\hline 1980 & 415 & 352 & 63 & 1,183 & 181 & 51 & 3,223 & 484 & 211 & 464 & 2,064 \\
\hline 1981 & 412 & 351 & 61 & 1,114 & 175 & 50 & 3,209 & 457 & 219 & 465 & 2,068 \\
\hline 1982 & 403 & 344 & 59 & 1,074 & 167 & 43 & 3,092 & 398 & 204 & 451 & 2,040 \\
\hline
\end{tabular}


Table F.2: Persons Engaged (000s) (cont.)

\begin{tabular}{|c|c|c|c|c|c|c|c|c|c|c|c|}
\hline & \multicolumn{3}{|c|}{ Germany } & \multicolumn{3}{|c|}{ United Kingdom } & \multicolumn{5}{|c|}{ United States } \\
\hline & Transport & Railways & $\begin{array}{l}\text { Water } \\
\text { transport }\end{array}$ & Transport & Railways & $\begin{array}{c}\text { Air } \\
\text { transport }\end{array}$ & Transport & Railways & $\begin{array}{l}\text { Water } \\
\text { transport }\end{array}$ & $\begin{array}{c}\text { Air } \\
\text { transport }\end{array}$ & $\begin{array}{c}\text { Other inland } \\
\text { transport \& } \\
\text { transport } \\
\text { services } \\
\end{array}$ \\
\hline 1983 & 387 & 331 & 56 & 1,049 & 159 & 39 & 3,080 & 358 & 193 & 458 & 2,072 \\
\hline 1984 & 371 & 317 & 54 & 1,053 & 154 & 42 & 3,248 & 358 & 195 & 493 & 2,203 \\
\hline 1985 & 357 & 304 & 53 & 1,050 & 146 & 45 & 3,338 & 335 & 191 & 528 & 2,283 \\
\hline 1986 & 346 & 294 & 52 & 1,027 & 142 & 47 & 3,380 & 308 & 184 & 564 & 2,324 \\
\hline 1987 & 334 & 286 & 48 & 1,014 & 139 & 48 & 3,529 & 287 & 181 & 607 & 2,454 \\
\hline 1988 & 319 & 275 & 44 & 1,047 & 134 & 57 & 3,678 & 278 & 176 & 647 & 2,577 \\
\hline 1989 & 306 & 263 & 43 & 1,065 & 131 & 63 & 3,775 & 273 & 180 & 694 & 2,628 \\
\hline 1990 & 299 & 255 & 44 & 1,098 & 130 & 67 & 3,829 & 260 & 185 & 751 & 2,633 \\
\hline 1991 & 293 & 248 & 45 & 1,072 & 133 & 70 & 3,838 & 251 & 194 & 737 & 2,656 \\
\hline 1992 & 288 & 243 & 45 & 1,050 & 134 & 69 & 3,850 & 243 & 179 & 729 & 2,699 \\
\hline 1993 & 275 & 233 & 42 & 1,031 & 125 & 68 & 4,000 & 238 & 182 & 742 & 2,838 \\
\hline 1994 & 263 & 224 & 39 & 1,017 & 120 & 68 & 4,192 & 233 & 187 & 756 & 3,016 \\
\hline 1995 & 244 & 207 & 37 & 1,021 & 112 & 73 & 4,319 & 232 & 189 & 787 & 3,111 \\
\hline 1996 & 236 & 200 & 36 & 990 & 80 & 78 & 4,462 & 224 & 185 & 1,126 & 2,927 \\
\hline
\end{tabular}


Table F.3: Annual Hours Worked per Person Engaged

\begin{tabular}{|c|c|c|c|c|c|c|c|c|c|}
\hline & \multicolumn{3}{|c|}{ Germany } & \multirow{2}{*}{ 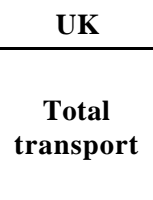 } & \multicolumn{5}{|c|}{ United States } \\
\hline & $\begin{array}{c}\text { Total } \\
\text { transport }\end{array}$ & Railways & $\begin{array}{c}\text { Water } \\
\text { transport }\end{array}$ & & $\begin{array}{c}\text { Total } \\
\text { Transport }\end{array}$ & Railways & $\begin{array}{c}\text { Water } \\
\text { transport }\end{array}$ & $\begin{array}{c}\text { Air } \\
\text { transport }\end{array}$ & $\begin{array}{c}\text { Other inland } \\
\text { transport \& } \\
\text { transport } \\
\text { services }\end{array}$ \\
\hline 1970 & 2,079 & 1,922 & 2,203 & 2,007 & 1,972 & 1,958 & 1,963 & 1,961 & 1,980 \\
\hline 1971 & 2,075 & 1,922 & 2,183 & 2,014 & 1,969 & 1,955 & 1,960 & 1,958 & 1,977 \\
\hline 1972 & 2,037 & 1,885 & 2,144 & 1,988 & 1,969 & 1,956 & 1,961 & 1,959 & 1,976 \\
\hline 1973 & 2,004 & 1,855 & 2,108 & 2,003 & 1,965 & 1,954 & 1,958 & 1,956 & 1,971 \\
\hline 1974 & 1,978 & 1,832 & 2,082 & 2,048 & 1,932 & 1,919 & 1,923 & 1,922 & 1,939 \\
\hline 1975 & 1,931 & 1,783 & 2,037 & 2,072 & 1,905 & 1,890 & 1,893 & 1,893 & 1,913 \\
\hline 1976 & 1,959 & 1,826 & 2,002 & 2,050 & 1,901 & 1,888 & 1,891 & 1,890 & 1,908 \\
\hline 1977 & 1,928 & 1,796 & 1,970 & 2,043 & 1,892 & 1,879 & 1,883 & 1,881 & 1,898 \\
\hline 1978 & 1,916 & 1,780 & 1,962 & 2,016 & 1,887 & 1,875 & 1,877 & 1,876 & 1,893 \\
\hline 1979 & 1,886 & 1,748 & 1,928 & 2,046 & 1,880 & 1,868 & 1,873 & 1,870 & 1,886 \\
\hline 1980 & 1,852 & 1,723 & 1,903 & 2,049 & 1,833 & 1,818 & 1,821 & 1,821 & 1,841 \\
\hline 1981 & 1,840 & 1,719 & 1,887 & 2,026 & 1,800 & 1,781 & 1,785 & 1,784 & 1,809 \\
\hline 1982 & 1,831 & 1,719 & 1,853 & 1,990 & 1,774 & 1,751 & 1,755 & 1,753 & 1,786 \\
\hline
\end{tabular}


Table F.3: Annual Hours Worked per Person Engaged (cont.)

\begin{tabular}{|c|c|c|c|c|c|c|c|c|c|}
\hline & \multicolumn{3}{|c|}{ Germany } & \multirow{2}{*}{$\begin{array}{c}\text { UK } \\
\begin{array}{c}\text { Total } \\
\text { transport }\end{array}\end{array}$} & \multicolumn{5}{|c|}{ United States } \\
\hline & $\begin{array}{c}\text { Total } \\
\text { transport }\end{array}$ & Railways & $\begin{array}{l}\text { Water } \\
\text { transport }\end{array}$ & & $\begin{array}{c}\text { Total } \\
\text { Transport }\end{array}$ & Railways & $\begin{array}{c}\text { Water } \\
\text { transport }\end{array}$ & $\underset{\text { Air }}{\text { transport }}$ & $\begin{array}{c}\text { Other inland } \\
\text { transport \& } \\
\text { transport } \\
\text { services } \\
\end{array}$ \\
\hline 1983 & 1,822 & 1,712 & 1,841 & 2,035 & 1,785 & 1,762 & 1,769 & 1,764 & 1,795 \\
\hline 1984 & 1,817 & 1,700 & 1,833 & 2,032 & 1,823 & 1,806 & 1,812 & 1,808 & 1,831 \\
\hline 1985 & 1,800 & 1,677 & 1,809 & 2,028 & 1,864 & 1,851 & 1,856 & 1,853 & 1,869 \\
\hline 1986 & 1,796 & 1,680 & 1,808 & 2,012 & 1,852 & 1,837 & 1,845 & 1,839 & 1,857 \\
\hline 1987 & 1,793 & 1,675 & 1,786 & 1,994 & 1,874 & 1,863 & 1,868 & 1,863 & 1,879 \\
\hline 1988 & 1,800 & 1,681 & 1,792 & 2,007 & 1,834 & 1,819 & 1,823 & 1,820 & 1,840 \\
\hline 1989 & 1,772 & 1,650 & 1,788 & 2,023 & 1,842 & 1,829 & 1,835 & 1,831 & 1,847 \\
\hline 1990 & 1,724 & 1,623 & 1,777 & 1,944 & 1,851 & 1,840 & 1,847 & 1,842 & 1,855 \\
\hline 1991 & 1,707 & 1,616 & 1,761 & 1,898 & 1,832 & 1,821 & 1,828 & 1,823 & 1,836 \\
\hline 1992 & 1,725 & 1,633 & 1,779 & 1,901 & 1,828 & 1,817 & 1,819 & 1,818 & 1,832 \\
\hline 1993 & 1,718 & 1,625 & 1,771 & 1,941 & 1,835 & 1,822 & 1,829 & 1,824 & 1,839 \\
\hline 1994 & 1,724 & 1,631 & 1,777 & 1,923 & 1,843 & 1,836 & 1,839 & 1,837 & 1,845 \\
\hline 1995 & 1,715 & 1,622 & 1,767 & 1,898 & 1,855 & 1,850 & 1,853 & 1,851 & 1,857 \\
\hline 1996 & 1,719 & 1,626 & 1,772 & 1,890 & 1,853 & 1,847 & 1,850 & 1,847 & 1,856 \\
\hline
\end{tabular}


Table F.4: Index of Capital Services (1993=100)

\begin{tabular}{|c|c|c|c|c|c|c|c|c|c|c|c|}
\hline & \multicolumn{3}{|c|}{ Germany } & \multicolumn{3}{|c|}{ United Kingdom } & \multicolumn{5}{|c|}{ United States } \\
\hline & $\begin{array}{c}\text { Total } \\
\text { transport }\end{array}$ & Railways & $\begin{array}{c}\text { Water } \\
\text { transport }\end{array}$ & $\begin{array}{c}\text { Total } \\
\text { transport }\end{array}$ & Railways & $\underset{\text { Aransport }}{\text { Air }}$ & $\begin{array}{c}\text { Total } \\
\text { transport }\end{array}$ & Railways & $\begin{array}{c}\text { Water } \\
\text { transport }\end{array}$ & $\underset{\text { Air }}{\text { Airansport }}$ & $\begin{array}{c}\text { Other inland } \\
\text { transport \& } \\
\text { transport } \\
\text { services }\end{array}$ \\
\hline 1970 & 74.8 & 93.8 & 87.7 & 82.2 & 90.6 & 89.7 & 96.6 & 98.7 & 89.7 & 58.8 & 92.4 \\
\hline 1971 & 78.6 & 95.1 & 98.4 & 84.3 & 90.1 & 99.3 & 97.1 & 98.1 & 92.1 & 57.6 & 95.4 \\
\hline 1972 & 81.3 & 95.9 & 107.2 & 87.3 & 88.5 & 103.4 & 98.4 & 97.3 & 96.8 & 59.0 & 99.1 \\
\hline 1973 & 83.3 & 96.8 & 111.4 & 90.8 & 84.5 & 103.1 & 102.2 & 97.3 & 105.4 & 64.4 & 105.9 \\
\hline 1974 & 85.0 & 97.7 & 117.2 & 93.1 & 81.9 & 103.7 & 105.6 & 110.9 & 110.0 & 66.2 & 111.2 \\
\hline 1975 & 86.1 & 98.4 & 117.0 & 94.0 & 81.0 & 101.5 & 107.1 & 121.7 & 117.0 & 67.2 & 110.9 \\
\hline 1976 & 87.4 & 99.0 & 118.7 & 94.4 & 80.3 & 104.5 & 108.1 & 120.7 & 122.4 & 66.2 & 114.6 \\
\hline 1977 & 89.1 & 99.5 & 122.4 & 95.8 & 80.2 & 105.9 & 109.2 & 120.3 & 129.5 & 68.2 & 117.2 \\
\hline 1978 & 90.6 & 99.9 & 124.0 & 97.7 & 80.5 & 106.5 & 110.1 & 120.7 & 134.1 & 71.3 & 118.8 \\
\hline 1979 & 91.5 & 99.7 & 122.3 & 98.9 & 79.9 & 117.2 & 113.6 & 122.3 & 137.7 & 76.2 & 123.4 \\
\hline 1980 & 91.9 & 99.5 & 120.3 & 98.7 & 78.6 & 128.1 & 115.8 & 123.5 & 138.6 & 82.2 & 123.4 \\
\hline 1981 & 92.5 & 99.2 & 119.9 & 95.3 & 76.9 & 116.7 & 115.3 & 122.5 & 140.3 & 84.4 & 120.9 \\
\hline 1982 & 92.4 & 99.0 & 118.4 & 92.4 & 75.4 & 95.7 & 113.0 & 120.5 & 138.8 & 82.7 & 117.8 \\
\hline
\end{tabular}


Table F.4: Index of Capital Services (1993=100) (cont.)

\begin{tabular}{|c|c|c|c|c|c|c|c|c|c|c|c|}
\hline & \multicolumn{3}{|c|}{ Germany } & \multicolumn{3}{|c|}{ United Kingdom } & \multicolumn{5}{|c|}{ United States } \\
\hline & $\begin{array}{c}\text { Total } \\
\text { transport }\end{array}$ & Railways & $\begin{array}{l}\text { Water } \\
\text { transport }\end{array}$ & $\begin{array}{c}\text { Total } \\
\text { transport }\end{array}$ & Railways & $\begin{array}{c}\text { Air } \\
\text { transport }\end{array}$ & $\begin{array}{c}\text { Total } \\
\text { transport }\end{array}$ & Railways & $\begin{array}{l}\text { Water } \\
\text { transport }\end{array}$ & $\begin{array}{c}\text { Air } \\
\text { transport }\end{array}$ & $\begin{array}{c}\text { Other inland } \\
\text { transport } \& \\
\text { transport } \\
\text { services }\end{array}$ \\
\hline 1983 & 93.1 & 98.9 & 121.1 & 91.1 & 74.3 & 93.5 & 111.3 & 116.2 & 133.7 & 82.3 & 120.0 \\
\hline 1984 & 93.3 & 98.8 & 121.4 & 91.3 & 73.7 & 96.2 & 109.9 & 112.6 & 128.7 & 79.7 & 123.2 \\
\hline 1985 & 94.1 & 98.9 & 121.6 & 91.7 & 74.3 & 98.7 & 107.7 & 110.1 & 123.2 & 79.3 & 120.7 \\
\hline 1986 & 94.9 & 99.2 & 119.9 & 90.8 & 74.2 & 93.0 & 107.8 & 107.9 & 119.0 & 85.2 & 122.3 \\
\hline 1987 & 95.0 & 99.6 & 114.7 & 90.6 & 74.9 & 86.7 & 106.1 & 105.6 & 115.2 & 86.8 & 120.4 \\
\hline 1988 & 95.2 & 99.8 & 107.3 & 90.6 & 76.7 & 82.6 & 105.4 & 104.2 & 111.5 & 89.1 & 119.1 \\
\hline 1989 & 96.0 & 99.8 & 103.8 & 90.7 & 79.7 & 81.9 & 104.8 & 102.9 & 108.8 & 92.0 & 117.8 \\
\hline 1990 & 97.4 & 100.0 & 101.7 & 90.7 & 83.1 & 83.6 & 103.9 & 102.1 & 106.1 & 95.2 & 113.5 \\
\hline 1991 & 99.1 & 100.1 & 100.3 & 92.5 & 87.6 & 83.4 & 101.7 & 100.9 & 103.3 & 95.1 & 107.8 \\
\hline 1992 & 99.8 & 99.9 & 99.6 & 95.5 & 94.0 & 87.9 & 100.7 & 99.9 & 101.0 & 99.1 & 102.8 \\
\hline 1993 & 100.0 & 100.0 & 100.0 & 100.0 & 100.0 & 100.0 & 100.0 & 100.0 & 100.0 & 100.0 & 100.0 \\
\hline 1994 & 99.9 & 100.1 & 99.2 & 104.8 & 102.8 & 121.3 & 99.2 & 101.6 & 98.3 & 96.4 & 99.7 \\
\hline 1995 & 100.1 & 99.9 & 98.4 & 105.9 & 102.3 & 114.4 & 99.3 & 102.5 & 97.2 & 94.2 & 100.7 \\
\hline
\end{tabular}


Table F.5: Shares of Labour Income in Value Added

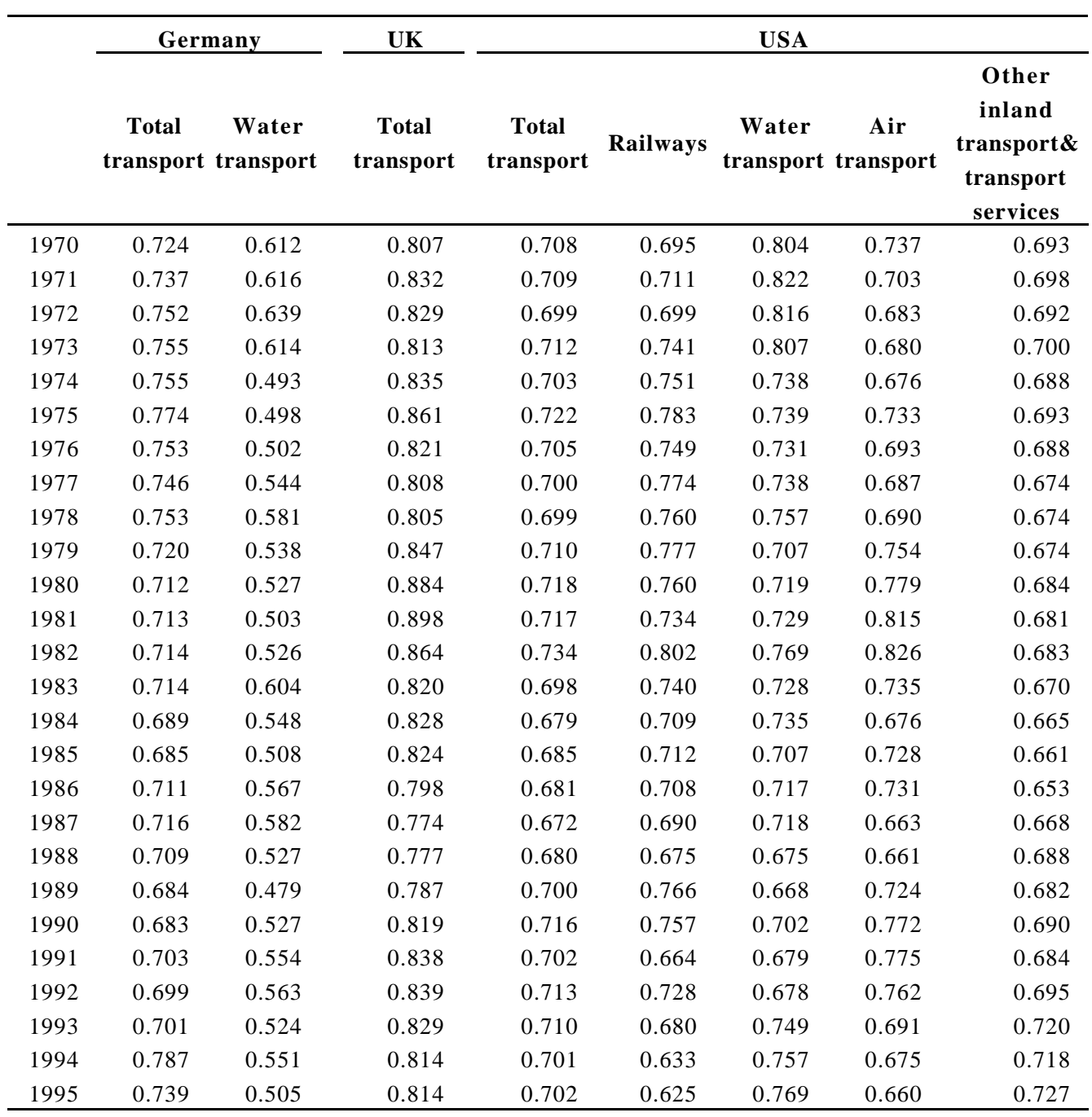





\section{REFERENCES}

Andrieu, H. (1984), "Note rétrospective sur le financement des investissements de transports (dépenses nettes)", mimeo, Transport Ministry, Paris.

Australian Bureau of Industry Economics (1992), "International Performance Indicators: Road Freight", Research Report, No. 46, AGPS, Canberra, December.

--- (1994), "International Performance Indicators: Aviation", Research Report, No.59, Australian Government Printing Service (AGPS), Canberra, August.

--- (1995a), "International Performance Indicators: Coastal Shipping 1995”, Research Report, No. 68, AGPS, Canberra, July.

--- (1995b), "International Performance Indicators: Waterfront", Research Report, No. 95/16, AGPS, Canberra, August.

--- (1995c), “Overview 1995 - International Benchmarking”, Research Report, No.95/20, AGPS, Canberra, November.

--- (1995d), "Rail Freight 1995 - International Benchmarking”, Research Report, No. 95/22, AGPS, Canberra, December.

Cockburn, I. and M. Frank (1992), "Market Conditions and Retirement of Physical Capital: Evidence from Oil Tankers", paper presented at the workshop on the Measurement of Depreciation and Capital Stock at the Conference on Research in Income and Wealth, National Bureau of Economic Research, Washington DC, 5 June.

Christensen, L.R. and D.W. Jorgenson (1969), “The Measurement of US Real Capital Input, 1929-1967, Review of Income and Wealth, Vol. 15, pp. 293-320.

Denison, E.F. (1967), Why Growth Rates Differ, The Brookings Institution, Washington DC.

Department of Commerce, Bureau of Economic Analysis (1985), "Fixed Private Capital in the United States”, Survey of Current Business, No. 7, July, pp. 36-47.

--- (1999), Fixed Reproducible Tangible Wealth of the United States, 1925-97, CD-rom, Washington DC

Dept. of the Treasury, Office of Tax Analysis (1991), "Report to Congress on the Depreciation of Business-Use Light Trucks”, Washington DC.

Freeman, K.F., T.H. Oum, M.W. Thretheway and W.G. Waters II (1987), The Growth and Performance of the Canadian Transcontinental Railways 1956-1981, Centre for Transportation Studies, University of British Columbia, Vancouver. 
Fraumeni, B.M. (1997), "The Measurement of Depreciation in the U.S. National Income and Product Accounts," Survey of Current Business, July 1997, pp. 7-23.

Gillen,D.W., T.H. Oum and M.W.Tretheway (1985), "Airline Cost and Performance: Implications for Policy and Industry Policies",Centre for Transportation Studies, University of British Columbia, Vancouver.

Goldsmith, R. (1951), “A Perpetual Inventory of National Wealth”, in M.R. Gainsburgh (ed.), Studies in Income and Wealth, No. 14, Princeton.

Hall, R.E. (1971), “The Measurement of Quality Changes from Quality from Vintage Price Data", in Z. Griliches (ed. ), Price Indexes and Quality Changes, Harvard University Press, Cambridge MA.

Harper, M.J., E.R. Berndt, and D.O. Wood (1989); "Rates of Return and Capital Aggregation Using Alternative Rental Prices"; in Jorgenson, Dale W. and Ralph Landau (eds.); Technology and Capital Formation, MIT Press.

Hensher, D.A., and R. Daniels, and I. De Mellow (1995), “A Comparative Assessment of the Productivity of Australia's Public Rail Systems 1971/72-1991/92", Journal of Productivity Analysis; Vol. 6, No. 3, September, pp. 201-23.

Hooper, P.G., D.A. Hensher (1997), "Measuring Total Factor Productivity of Airports-An Index Number Approach", Transportation-Research: Part-E:-Logistics-andTransportation-Review; Vol. 33, No. 4, December, pp. 249-59.

Jorgenson, D.W., F.M. Gollop and B.M. Fraumeni (1987), Productivity and U.S. Economic Growth, Harvard University Press, Harvard.

Kuznets, S. (1957), "Quantitative Aspects of the Economic Growth of Nations: II. Industrial Distribution of National Product and Labor Force", Economic Development and Cultural Change, Vol. 5, No. 4, Supplement, pp. S3-61.

Lawrence, D., J. Houghton and A. George (1997), "International Comparisons of Australia's Infrastructure Performance", Journal of Productivity Analysis, Vol. 8, pp. 361-78.

Lorentz, G. (1987), “Construction des séries longues consolidées: Etats, collectivités territoriales, grandes entreprises nationales et autres intervenants, mimeo, Ministry of Transport, Paris.

Mairesse, J. (1972), "L'évaluation du capital fixe productif: méthodes et résultats", Les Collections de l'INSEE, No. C18-19/1972, Paris.

Musgrave J.C. (1990), “Government Owned Fixed Capital in the United States, 1925-79”, Survey of Current Business, March, pp. 33-43.

National Statistical Office (various issues), “The Capital Account”, National Accounts Concepts, Sources and Methods, NSO, London. 
OECD (1993), Methods Used by OECD Countries to Measure Stocks of Fixed Capital, National Accounts: Sources and Methods, No. 2, Paris.

O’Mahony, M. (1998), “Capital and Productivity”, mimeo, NIESR, London.

--- (1999), Britain's Productivity Performance 1950-1996 - An International Perspective, 1950-1996, NIESR, London.

Oum, T.H. and C. Yu (1998), Winning Airlines; Productivity and Cost Competitiveness of the World's Major Airlines, Kluwer Academic Publishers.

Patrice, M. and A. Pachomoff (1999), "Estimation de l'investissement en infrastructures routières", mimeo, Ministry of Transport, Paris.

Pereira da Silva, L. (around 1980), "Evaluation des investissements transports par la mesure et l'analyse d'impacts macro-économiques", paper presented at twelfth Summer Annual Meeting of the Seminar on Transport Policy.

Quinet, E., C. Roy, D. Schwartz, J.P. Tharoux (1994), Le coût du capital des infrastructures des transports, rapport final, Observatoire économique et statistique des transports, Transport Ministry, Paris.

Toutain, J.C. (1967), "Les transports en France de 1830 à 1965”, P.U.F., Cahiers de l'ISEA, serie "Histoire quantitative de l'économie française", No. 8, September, October.

Tretheway, M.W., W.G. Waters II and AK. Fok (1994), "Measuring Productivity and Financial Returns for Canadian National Railway and CP Rail, 1956-1991”, Monograph, Centre for Transportation Studies, University of British Colombia.

Ulmer, M.J. (1960), Capital in Transportation, Communication and Public Utililites: Its Formation and Financing, Princeton University Press, NBER, Princeton.

Villa, P. (1993), Une analyse macroéconomique de la France au XXe siècle, CNRS, Paris.

Waters, W.G. (1997), "The Total Factor Productivity of Canadian National and CP Rail: An Update and Extension to the UBC Rail Productivity Study", mimeo, Centre for Transportation Studies, University of British Columbia. 



\section{SOURCES STATISTIQUES}

Airclaims (various issues), Client Aviation System Enquiry (CASE) Database, London.

Airliner Price Guide Inc. (various issues), The Airliner Price Guide, Oklahoma, OK.

Air France (various issues), Bilan annuel, Paris.

Air Inter (various issues), Bilan annuel, Paris.

Centre d'Etudes sur les Reseaux, les Transports et l'Urbanisme, L'annuaire statistique des transports collectifs urbains.

Ministry of Transport (Ministère de l'Aménagement du Territoire, de l'Equipment et des Transport, Observatoire Economique et Statistique des Transports) (1995), Les performances des entreprises du transport routier de marchandises: Evolution de 1988 à 1993, Paris.

Ministry of Transport (Ministère de l'Equipement, des Transports et du Logement, Direction des Affaires Economiques et Internationales) (1998), Les performances des entreprises du transport routier de marchandises de 1993 à 1995, Paris.

--- (various issues), Enquête annuelle d'entreprise, Paris.

--- (various issues), Les comptes de transports, Paris.

---, Secretariat of Maritime Transport, Directorate of the Maritime Fleet, Bureau for Economic Studies and Statistics ( Secretariat d'état à la mèr, Direction de la flotte de commerce, bureau des études économiques et statistiques) (various issues), Flotte de commerce sous pavillon française, Paris.

RATP (various issues), Bilan annuel, Paris.

--- (various issues), Rapport d'activité, Paris.

SNCF (various issues), Bilan annuel, Paris.

--- (various issues), Rapport sur les comptes d'excercise, Paris. 



\section{LIST OF WORKING PAPERS RELEASED BY CEPII ${ }^{26}$}

\section{0}

"Programme de travail 2001", working paper $n^{\circ} 00.17$, December.

"La gestion des crises de liquidité internationale : logique de faillite, prêteur en dernier ressort et conditionnalité", J. Sgard, working paper $n^{\circ} 00.16$, November.

"La mesure des protections commerciales nationales", A. Bouët, working paper $n^{\circ} 00.15$, November.

"The Convergence of Automobile Prices in the European Union : an Empirial Analysis for the Period 1993-1999", G. Gaulier and S. Haller, working paper $n^{\circ} 00.14$, November.

"Internaitonal Trade and Firms' Hetterogeneity Under Monopolistic Competition", S. Jean, working paper $n^{\circ} 00-13$, September.

"Syndrome, miracle, modèle polder et autres spécificités néerlandaises: quels enseignements pour l'emploi en France ?", S. Jean, working paper $n^{\circ} 00-12$, July.

"FDI and the Opening Up of China’s Economy, F. Lemoine, working paper $n^{\circ} 00-11$, June.

"Big and Small Currencies : The Regional Connection", A. Bénassy-Quéré and B. Coeuré, working paper $n^{\circ} 00-10$, June.

"Structural Changes in Asia and Growth Prospects After the Crisis", J.C. Berthélemy and S. Chauvin, working paper $n^{\circ} 00-09$, June.

"The International Monetary Fund and the International Financial Architecture", M Aglietta, working paper $n^{\circ} 00-08$, May.

"The Effect of International Trade on Labour-Demand Elasticities : Intersectoral Matters", S. Jean, working paper $n^{\circ} 00-07$, May

"Foreign Direct Investment and the Prospects for Tax Co-Ordination in Europe", working paper $n^{\circ}$ 00-06, April.

"Forum Economique Franco-Allemand Deutsch-Französisches Wirtschaftspolitisches Forum, Economic Growth in Europe: Entering a New Area? The First Year of EMU, $6^{\text {h }}$ meeting, Paris, January 17-18, 2000", working paper $n^{\circ}$ 00-05, April.

\footnotetext{
${ }^{26}$ Working papers are circulated free of charge as far as stocks are available; thank you to send your request to CEPII, Sylvie Hurion, 9 rue Georges Pitard, 75015 Paris, or by fax (33) 0153685504 or by e-mail Hurion@ cepii.fr. CEPII is also on the Web : http://www.cepii.fr.
} 
"The Expectations of Hong Kong Dollar Devaluation and their Determinants", B. Rzepkowski, working paper $n^{\circ}$ 00-04, February. OUT-OF-PRINT

"What Drove Relative Wages in France? Structural Decomposition Analysis in a General Equilibrium Framework, 1970-1992", S. Jean and O. Bontout, working paper $n^{\circ}$ 00-03, January.

"Le passage des retraites de la répartition à la capitalisation obligatoire : des simulations à l'aide d'une maquette", O. Rouguet and P. Villa, working paper $n^{\circ}$ 00-02, January.

"Rapport d'activité 1999", working paper n00-01, January.

\section{9}

"Exchange Rate Strategies in the Competition for Attracting FDI", A. Bénassy-Quéré, L. Fontagné and A. Lahrèche-Révil, working paper $n^{\circ}$ 99-16, December.

"Groupe d'échanges et de réflexion sur la Caspienne. Recueil des comptes-rendus de réunion (déc. 97-oct. 98)", D. Pianelli and G. Sokoloff, working paper $n^{\circ}$ 99-15, November.

"The Impact of Foreign Exchange Interventions: New Evidence from FIGARCH Estimations", M.Beine, A. Bénassy-Quéré and C. Lecourt, working paper $n^{\circ} 99-14$, September.

"Forum Economique Franco-Allemand Deutsch-Französisches Wirtschaftspolitisches Forum", Reduction of Working Time/Eastward Enlargment of the European Union, $5^{\text {th }}$ meeting, Paris, July 6-7 1999", working paper $n^{\circ}$ 99-13, September.

"A Lender of Last Resort for Europe", M. Aglietta, working paper $n^{\circ}$ 99-12, September. OUT-OF-PRINT

"La diversité des marchés du travail en Europe : Quelles conséquences pour l’Union Monétaire ; Deuxième partie : Les implications macro-économiques de la diversité des marchés du travail", L. Cadiou, S. Guichard and M. Maurel, working paper $n^{\circ}$ 99-11, June.

"La diversité des marchés du travail en Europe : Quelles conséquences pour l’Union Monétaire ; Première partie : La diversité des marchés du travail dans les pays de l'Union Européenne", L. Cadiou and S. Guichard, working paper $n^{\circ}$ 99-10, June.

"The Role of External Variables in the Chinese Economy; Simulations from a macroeconometric model of China", S. Dees, working paper $n^{\circ}$ 99-09, June.

"Haute technologie et échelles de qualité : de fortes asymétries en Europe", L. Fontagné, M. Freudenberg and D. Ünal-Kesenci, working paper $n{ }^{\circ} 99-08$, June. 
"The Role of Capital Accumultion, Adjustment and Structural Change for Economic TakeOff: Empirical Evidence from African Growth Episodes", J.C. Berthélemy and L. Söderling, working paper $n^{\circ}$ 99-07, April.

"Enterprise Adjustment and the Role of Bank Credit in Russia: Evidence from a 420 Firm's Qualitative Survey", S. Brana, M. Maurel and J. Sgard, working paper $n^{\circ}$ 99-06, April.

"Central and Eastern European Countries in the International Division of Labour in Europe", M. Freudenberg and F. Lemoine, working paper $n^{\circ}$ 99-05, April.

"Forum Economique Franco-Allemand - Economic Policy Coordination $-4^{\text {th }}$ meeting, Bonn, January 11-12 1999", working paper n 99-04, April.

"Models of Exchange Rate Expectations : Heterogeneous Evidence From Panel Data", A. Bénassy-Quéré, S. Larribeau and R. MacDonald, working paper $n^{\circ}$ 99-03, April.

"Forum Economique Franco-Allemand - Labour Market \& Tax Policy in the EMU", working paper $n^{\circ}$ 99-02, March.

"Programme de travail 1999", working paper $n^{\circ}$ 99-01, January.

\section{8}

"Rapport d'activité 1998", working paper n98-15, December.

"Monetary Policy under a Fixed Exchange Rate Regime, The Case of France 1987-1996", B. Mojon, working paper $n^{\circ} 98-14$, December.

"Wages and Unemployment: Trade-off Under Different Labour Market Paradigms", O. Bontout and S. Jean, working paper $n^{\circ} 98-13$, November.

"Structures financières et transmission de la politique monétaire, analyses comparatives de l'Allemagne, la France, l'Italie et le Royaume-Uni", B. Mojon, working paper $n^{\circ}$ 98-12, October.

"Le marché du travail britannique vu de France", M. Fouquin, S. Jean and A. Sztulman, working paper $n^{\circ} 98-11$, October.

"Compétitivité et régime de change en Europe Centrale", M.Aglietta, C. Baulant and V. Coudert, working paper $n^{\circ} 98-10$, October.

"Sensibilité des salaires relatifs aux chocs exogènes de commerce international et de progrès technique : une évaluation d'équilibre général", S. Jean and O. Bontout, working paper $n^{\circ}$ 98-09, September. 
"Evolution sur longue période de l'intensité énergétique", P. Villa, working paper $n^{\circ}$ 98-08, August.

"Sacrifice Ratios in Europe : a Comparison", L. Boone, B. Mojon, working paper $n^{\circ}$ 98-07, August.

"La politique monétaire et la crise japonaise", S. Guichard, working paper $n^{\circ}$ 98-06, July.

"La régionalisation du commerce international : une évaluation par les intensités relatives bilatérales", M. Freudenberg, G. Gaulier, D. Ünal-Kesenci, working paper $n^{\circ}$ 98-05, July.

"Pegging the CEEC's Currencies to the Euro", A. Bénassy-Quéré, A. Lahrèche-Révil, working paper $n^{\circ} 98-04$, July.

"The International Role of Euro", A. Bénassy-Quéré, B. Mojon, A.D. Schor, working paper $n^{\circ}$ 98-03, July.

"EMU and Transatlantic Exchange Rate Stability", A.Bénassy-Quéré and B. Mojon, working paper $n^{\circ}$ 98-02, April. OUT-OF-PRINT

"Programme de travail 1998", J.C. Berthélemy, working paper n98-01, April.

\section{7}

"Why the euro will be strong: an approach based on equilibrium exchange rates", M. Aglietta, C. Baulant and V. Coudert, working paper $n^{\circ}$ 97.18, December.

"How Foreign Direct Investment Affects International Trade and Competitiveness ; an Empirical Assessment", L. Fontagné and M. Pajot, working paper $n^{\circ}$ 97-17, December.

"Cycles de poduction industrielle : une analyse historique dans le domaine des fréquences", P. Villa, working paper $n^{\circ} 97-16$, November.

"Internal and External Policy Coordination : a Dynamic Analysis", F. Capoën and P. Villa, working paper $n^{\circ}$ 97-15, November.

"Optimal Pegs for Asian Currencies", A. Bénassy-Quéré, working paper $n^{\circ}$ 97-14, October. OUT-OF-PRINT

"Pour ou contre le système commun de TVA ? ", C. Lefebvre, working paper $n^{\circ}$ 97-13, June.

"The Euro and Exchange Rate Stability", A. Bénassy-Quéré, B. Mojon and J. Pisani-Ferry, working paper $n^{\circ} 97-12$, June. 
"Estimation du cycle à l'aide d'un modèle à tendance stochastique and application au cas du Royaume-Uni", L. Boone, working paper $n^{\circ}$ 97-11, June.

"Looking for French Monetary Policy", B. Mojon, working paper $n^{\circ}$ 97-10, June. OUT-OFPRINT

"Incertitude sur le choix du modèle et rationalité", P. Villa, working paper $n^{\circ}$ 97-09, May.

"Quel est l'impact du commerce extérieur sur la productivité et l'emploi ? ", O. Cortes and S. Jean, working paper $n^{\circ}$ 97-08, April.

"Trade Patterns Inside The single Market", L. Fontagné, M. Freudenberg and N. Péridy, working paper $n^{\circ}$ 97-07, April.

"The Exchange Rate Policy of the Euro: A Matter of Size", P. Martin, working paper $n^{\circ} 97$ 06, April. OUT-OF-PRINT

"Ces taux de de change réels qui bifurquent", P. Villa, working paper $n^{\circ}$ 97-05, April.

"Chômage non-qualifié et imitation : les raisons d'un accord international sur la propriété intellectuelle", L. Fontagné and J.L. Guérin, working paper $n^{\circ}$ 97-04, March.

"Symmetry and Assymmetry of Supply and Demand Shocks in the European Union: a Dynamic Analysis", L. Boone, working paper $n^{\circ}$ 97-03, February. OUT-OF-PRINT

"Interest Rates in East Asian Countries : Internal Financial Structures and International Linkages"., I. Bensidoun, V. Coudert and L. Nayman, working paper $n^{\circ}$ 97.02, January.

"Intra-Industry Trade: Methodological Issues Reconsidered", L. Fontagné and M. Freudenberg, working paper $n^{\circ} 97.01$, January. 